
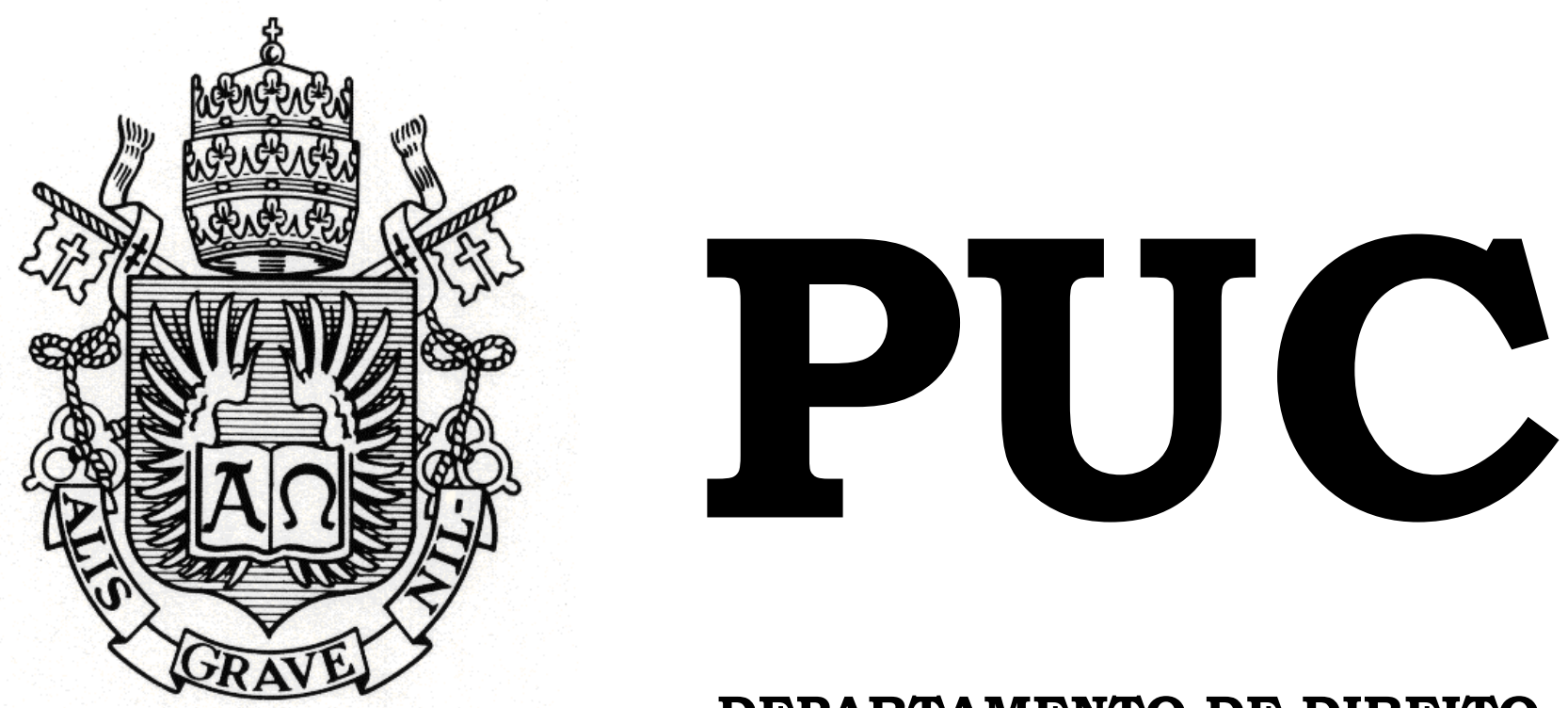

DEPARTAMENTO DE DIREITO

\title{
ATENIENSES DA AMÉRICA: POLITTICA E DIREITO NA INDEPENDÊNCIA DO BRASIL
}

por

GUILHERME LERER

ORIENTADOR: Pedro Marcos Nunes Barbosa 2018.2 


\title{
ATENIENSES DA AMÉRICA: POLÍTICA E DIREITO \\ NA INDEPENDÊNCIA DO BRASIL
}

\author{
por \\ GUILHERME LERER
}

Monografia apresentada ao Departamento de Direito da Pontificia Universidade Católica do Rio de Janeiro (PUC-Rio) para a obtenção do Título de Bacharel em Direito.

Orientador: Pedro Marcos
Nunes Barbosa

2018.2 
Dedicado à memória dos que morreram pelo Brasil e à esperança de um futuro melhor. 


\section{Agradecimentos}

Buscando fugir de clichês, começo justamente com um dos maiores: nada teria sido possível de concretizar sem o auxílio e o incentivo de inúmeras pessoas. Algumas pela ajuda material na confecção deste texto, algumas pelos conselhos e lições de vida que inspiraram as ideias aqui descritas, certo é que cada uma, ao seu jeito particular, foi fundamental na construção de uma ética pessoal, acadêmica e profissional que levo para frente.

Deixando de lado longas divagações sobre a importância da família e dos amigos - inolvidáveis, mas óbvias —, gostaria de agradecer inicialmente a Daniel Nogueira, meu irmão, que revisou, criticou e sugeriu incessantemente, tendo a inglória tarefa de ler e reler o texto ainda inacabado.

Se cheguei até aqui e escolhi este tema, muito se deve ao aprendizado e à convivência que tive com excelentes professores e profissionais na PUC-Rio. Nesse sentido, registro profundo respeito e sinceros agradecimentos a: Mauricio de Albuquerque Rocha, por mostrar a importância da leitura crítica, da análise política consciente e, acima de tudo, por ensinar, à ideia de Nelson Rodrigues, que as coisas ditas apenas uma vez morrem inéditas; Dante Braz Limongi, que sabe usar seu profundo conhecimento e percepção da História deste país para inspirar e cativar os seus alunos a entendê-lo e, esperançosamente, melhorá-lo; e Regina Coeli Lisbôa Soares, que, mesmo tendo visto de perto os episódios mais sombrios de nossa história recente, ensina a Constituição com obstinação e perseverança invejáveis e inspiradoras, mesmo contra todas as expectativas, provando que, não obstante as circunstâncias adversas, o Brasil triunfará contra todos os que lhe querem fazer mal.

Agradeço também a Pedro Paulo de Barros Barreto, meu mentor

profissional, que muito me ensinou sobre a advocacia, sobre o Direito e, 
mais importante, sobre ser um advogado correto, honesto e caridoso. O seu apoio na criação deste texto foi inestimável, e sua paixão pelo que faz me motiva a seguir a carreira.

Por fim, não poderia deixar de agradecer a Pedro Marcos Nunes Barbosa; apenas meu professor há quatro anos, hoje se tornou, além de orientador, um mentor e um amigo. Para além de seus méritos acadêmicos e profissionais - há muitas fontes melhores a respeito - , ele busca sempre o melhoramento dos que estão à sua volta: indica cursos, filmes, livros e músicas. Entende que a cultura erudita e a popular estão ligadas e que mostram, cada uma à sua maneira, lições e caminhos para se aprender e aplicar. Toda fonte de conhecimento é legítima; cabe a nós analisá-las para encontrar a melhor forma de pensar. 


\section{Resumo}

Às vésperas de se completarem duzentos anos da declaração de Independência do Brasil, parece ser necessário realizar uma autocrítica de nação. Frente às correntes políticas destrutivas que tomam conta do pensamento e do sentimento das massas, julgou-se prudente mergulhar nas origens do movimento que culminou na formação das instituições brasileiras, analisando-o sob diversos aspectos.

Primeiramente, pelo viés da política interna, este trabalho procura mostrar as continuidades históricas dos institutos jurídicos e políticos portugueses com os ideais que nortearam a separação dos países e a formação da única monarquia das Américas. A partir disso, busca estabelecer a relação do novo país com as potências da época, fazendo uma crônica do processo de reconhecimento da Independência brasileira por Portugal. Por fim, passando ao campo puramente jurídico, são analisadas as bases fundamentais entre política e direito na sociedade brasileira, estudando-se as discussões havidas na Assembleia Constituinte de 1823 e a Constituição que, indiretamente, dela surgiria.

Palavras-chave:

Independência; História do Direito; Direito Constitucional; Direito Internacional Público; Política; Liberdade; Legitimidade. 


\section{Sumário}

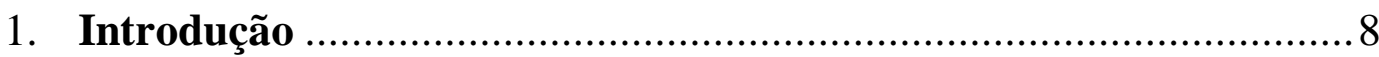

2. O movimento da Independência ............................................ 11

2.1. Ordem política interna: $1808-1815$...................................... 11

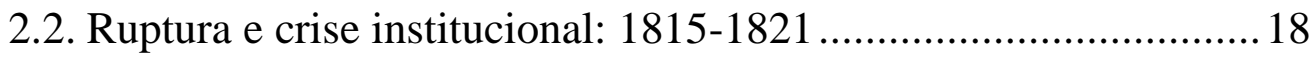

2.3. A reação nacional: 1821-1822 ............................................... 24

3. O reconhecimento da Independência ........................................... 33

3.1. Contexto político europeu e o papel do Reino Unido .................. 33

3.2. As Conferências de Londres ................................................. 41

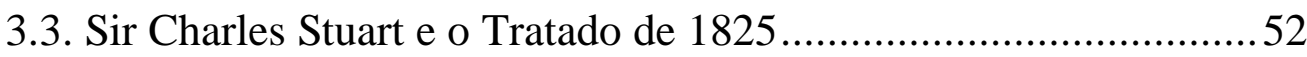

4. Formação constitucional do Império do Brasil ............................58

4.1. Política e Constituição .........................................................58

4.2. Os debates e a dissolução da Constituinte de 1823 .....................65

4.3. Constituição Imperial de 1824 ........................................... 85

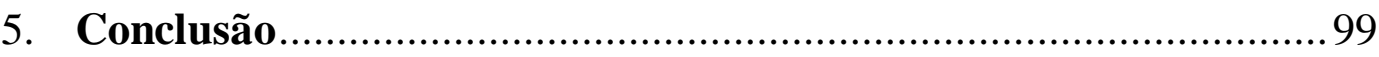

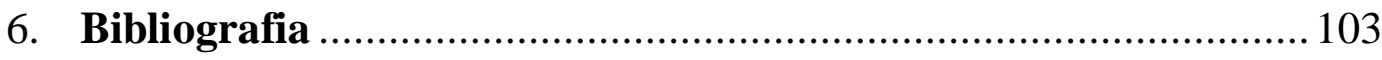


Dois movimentos são naturais para qualquer nação que derruba instituições julgadas opressoras e viciadas. O primeiro é o de querer ver tudo destruído e erigido de novo; o segundo, de demonstrar severidade implacável contra aqueles que lucraram com os vícios das instituições anteriores. Esses dois movimentos são precisamente os que tornam as revoluções horrendas, os que fazem as pessoas ultrapassarem suas necessidades, prolongam a duração dos levantes e põem em risco seu sucesso. Os homens ilustrados devem se esforçar para barrá-los e suspendê-los ${ }^{1}$.

Os brasileiros são entusiastas do belo ideal, amigos da sua liberdade e mal sofrem perder as regalias que uma vez adquiriram. Obedientes ao justo, inimigos do arbitrário, suportam o roubo melhor que o vilipêndio; ignorantes por falta de instrução, mas cheios de talento por natureza, de imaginação brilhante, e por isso amigos de novidades que prometem perfeição e enobrecimento; generosos, mas com bazófia; capazes de grandes ações, contanto que não exijam atenção aturada e não requeiram trabalho assíduo e monotônico; apaixonados do sexo por clima, vida e educação. Empreendem muito, acabam pouco. Sendo os atenienses da América, se não forem comprimidos e tiranizados pelo despotismo ${ }^{2}$.

${ }^{1}$ CONSTANT, Benjamin. Princípios de política aplicáveis a todos os governos. $1^{\text {a }}$ ed. Rio de Janeiro: Topbooks, 2007. P. 668.

${ }^{2}$ ANDRADA E SILVA, José Bonifácio de. Projetos para o Brasil. $1^{\text {a }}$ ed. São Paulo: Companhia das Letras e Publifolha, 2000. P. 97. 


\section{Introdução}

Os grandes revolucionários foram sempre perseguidos durante a vida; a sua doutrina foi sempre alvo do ódio mais feroz, das mais furiosas campanhas de mentiras e difamação por parte das classes dominantes. Mas, depois da sua morte, tenta-se convertê-los em ídolos inofensivos, canonizá-los por assim dizer, cercar o seu nome de uma auréola de glória, para "consolo" das classes oprimidas e para o seu ludíbrio, enquanto se castra a substância do seu ensinamento revolucionário, embotando-lhe o gume, aviltando-o ${ }^{3}$.

Está em voga discutir a história do Brasil. Os movimentos políticos recentes, à guisa de trazer inovações e de elevar o país a patamares nunca antes vistos, serviram para formar grupos dissonantes de ideologias opostas, cada qual defendendo o seu ponto de vista com a exclusão maniqueísta de todos os outros.

A polarização atual, que abrange os mais diversos assuntos, fornece um palanque para a intolerância, não obstante as fartas e numerosas lições que o Brasil vem coletando, desde seu descobrimento, em termos de autoritarismo. O problema, por óbvio, passa pela já tradicional educação deficiente e pelo desinteresse político na conscientização do povo brasileiro.

Sendo certo que a História é "uma poderosa construção ideológica que pode modelar nosso sentido da identidade social, e o nosso futuro nacional ou o nosso propósito social"4, tentou-se traçar, em linhas gerais, um quadro analítico do Brasil na época de sua Independência. Para isso, empreendeu-se um estudo sobre o surgimento das suas instituições e sobre os agentes preponderantes para a formação e a consolidação do país, buscando trazer à tona os aspectos fundamentais da nova sociedade brasileira, em termos sociais, políticos e normativos.

\footnotetext{
${ }^{3}$ LENIN, Vladimir Ilitch. O Estado e a Revolução: o que ensina o marxismo sobre o Estado e o papel do proletariado na Revolução. $1^{a}$ ed. São Paulo: Centauro, 2007. P. 23.

${ }^{4}$ RODRIGUES, José Honório. Independência: revolução e contra-revolução: a evolução política. $1^{\mathrm{a}}$ ed. Rio de Janeiro: F. Alves, 1975. v1. P. I.
} 
O período da Independência do Brasil, como não poderia deixar de ser, cristalizou-se na visão histórica nacional como um movimento pacífico, fruto da livre união do povo e dos ideais iluministas liberais; seria, em outras palavras, a realização de uma utopia desejada há tempos e realizada sem esforço. Nada mais falso: na realidade, a separação se deu como "fruto de um parto doloroso de uma nação formada por três séculos de aventuras e labores"5.

A narrativa de que D. Pedro I teria apenas assumido a gerência do país no lugar de seu pai foi utilizada, na historiografia tradicional, para pacificar e integrar as relações pessoais no Brasil. Procurava-se, com isso, gerar um senso de nacionalidade e de pertencimento na formação do povo, da mesma forma que a romantização de Tiradentes, dos bandeirantes, do "homem cordial" e da "democracia racial". A realidade, contudo, foi muito diversa. Longe de ter sido uma ruptura amena, o movimento de Independência do Brasil foi marcado pela participação internacional, notadamente da França e do Reino Unido, e pela incompatibilidade clamorosa entre os ideais liberalistas e a realidade patriarcal conservadora que dominava - e ainda domina - a sociedade brasileira.

Para melhor entender os processos que culminaram no reconhecimento da soberania brasileira, fez-se inicialmente um estudo sobre os movimentos e os grupos políticos que sustentaram, de forma heterogênea e assimétrica, a concessão e a manutenção da maior autonomia brasileira. Para isso, foi necessário analisar as instituições criadas e os atos normativos editados a partir da chegada da família real ao Brasil, já que "o processo da independência iniciou-se em 1808”.

\footnotetext{
${ }^{5}$ OLIVEIRA LIMA, Manuel de. Formação histórica da nacionalidade brasileira. $2^{\mathrm{a}}$ ed. Rio de Janeiro: Topbooks, 1997. P. 181.

${ }^{6}$ FAUSTO, Boris; HOLANDA, Sergio Buarque de. O Brasil monárquico: o processo de emancipação. $2^{\mathrm{a}}$ ed. São Paulo: Difusão Europeia do Livro, 1965. P. 135.
} 
Em seguida, foi necessário ultrapassar as fronteiras do território nacional, explorando o cenário político internacional e a participação diplomática de outros países no reconhecimento da Independência brasileira. Põe-se em evidência o papel fundamental do Secretário de Assuntos Estrangeiros do Reino Unido, George Canning, na mediação entre Portugal e Brasil, esmiuçando-se o conturbado ciclo de conferências que resultou, em 1825, na assinatura do Tratado de Independência.

Após ponderar as causas, internas e externas, da Independência de fato e da sua admissão pelas potências europeias, essencial voltar os olhos sobre a nova sociedade que estava se formando, procurando entender quais seriam seus valores e ideais basilares e como tais noções se consolidariam normativamente para construir a ordem jurídica inédita. Nesse intuito, foi feito um exame da natureza do poder constituinte, da sua relação com a política e das diversas teorias a respeito da soberania e da legitimidade.

Tomando essas observações como base, produziu-se uma crônica dos debates jurídicos havidos na Assembleia Constituinte de 1823, destacando as classes sociais e os interesses privados que guiaram tais discussões. Para estabelecer, por fim, a base normativa do Brasil independente, cotejou-se o projeto dessa Assembleia com a efetiva Constituição Imperial de 1824, fazendo um paralelo com a Constituição Federal de 1988 para ilustrar as numerosas semelhanças entre esses documentos.

Este trabalho se propõe a traçar os pontos fundamentais das instituições e das classes dominantes no Brasil, mostrando as características inerentes do comportamento brasileiro e de sua organização política. Em muitos casos, é possível verificar, com certa ironia, episódios de quase dois séculos atrás que seriam perfeitamente esperados nos tempos atuais; tentase mostrar que, com raras exceções, nada foi aprendido. Esperemos que o povo brasileiro, ignorante de sua História, não seja forçado a repeti-la. 


\section{O movimento da Independência}

\subsection{Ordem política interna: $\mathbf{1 8 0 8 - 1 8 1 5}$}

Na guerra entre a França e a Inglaterra, Portugal fazia o papel do marisco na luta entre o rochedo e o mar; apegava-se àquele, temia ser levado por este e falhavam-lhe os meios de abrandar-lhes o furor ${ }^{7}$.

A fuga da Família Real portuguesa ao Brasil, em 1808, foi o resultado complexo e único de muitos fatores. A supremacia militar de Napoleão na Europa continental, ligada à prevalência britânica no comércio marítimo e aos inúmeros tratados de aliança firmados entre o Reino Unido e Portugal, forçaram a monarquia portuguesa a se posicionar firmemente no cenário político do continente europeu.

Instalado o bloqueio continental ${ }^{8}$ em fins de 1806 , as atenções francesas se voltaram a Portugal, acreditando que o fechamento dos portos lusos seria o golpe final para o comércio britânico. Assim, o pequeno país ibérico se viu posto diretamente entre o seu mais antigo aliado - ao qual estava ligado diplomaticamente, no mínimo, desde o Tratado de Londres de 1642 - e o "furacão napoleônico"9 que lhe exigia a capitulação.

As exigências francesas, que incluíam o confisco de propriedades e embarcações dos súditos ingleses em território português, foram de pronto rechaçadas. Antevendo a situação crítica que iria se apresentar, o Reino Unido propôs a D. João VI a fuga ao Brasil, com promessa de sua assistência. O plano, além de frustrar a dominação territorial de Napoleão na Europa, colocava os britânicos em posição de superioridade e de crédito

7 MONTEIRO, Tobias. História do Império: a elaboração da Independência. $1^{\mathrm{a}}$ ed. Belo Horizonte: Itatiaia, 1981. P. 23.

${ }^{8} \mathrm{O}$ bloqueio foi uma estratégia econômica utilizada por Napoleão para impedir a proliferação do domínio britânico na mercancia marítima. Representou, acima de tudo, "uma arma ofensiva, arma de guerra: fechando os mercados do continente, procurava arruinar economicamente sua inimiga, para obrigá-la a render-se" (FAUSTO, Boris; HOLANDA, Sergio Buarque de. O Brasil monárquico: o processo de emancipação. P. 65).

${ }^{9}$ FAORO, Raymundo. Os donos do poder: formação do patronato político brasileiro. $5^{\mathrm{a}}$ ed. São Paulo: Globo, 2012. P. 285. 
em relação a Portugal e, por conseguinte, em condição privilegiada para explorar o mercado e os fartos recursos do Brasil.

A proeza de D. João VI, ainda que resultante de pressões externas e internas, foi única entre todos os soberanos da Europa que se viram defronte ao expansivo imperador dos franceses. Tal ousadia aumentou, mesmo a contrassenso, o seu prestígio entre os diplomatas e os políticos:

Retirando-se para a América, o príncipe regente, sem afinal perder mais do que o que possuía na Europa, escapava a todas as humilhações sofridas por seus parentes castelhanos, depostos a força, e além de dispor de todas as probabilidades para arredondar à custa da França e da Espanha inimigas o seu território ultramarino, mantinha-se na plenitude dos seus direitos, pretensões e esperanças. Era como que uma ameaça viva e constante à manutenção da integridade do sistema napoleônico. (...) Por isso é muito mais justo considerar a trasladação da corte para o Rio de Janeiro como uma inteligente e feliz manobra política do que como uma deserção covarde ${ }^{10}$.

Determinada e planejada a partida, D. João VI foi rápido em responder às epístolas de Napoleão, fingindo aceitar suas determinações, na tentativa de ganhar mais tempo para os preparativos da viagem. Nesse intuito, chegou até mesmo a decretar a proibição de desembarque dos navios ingleses em território lusitano, medida que foi corretamente vista pelos britânicos como inócua, reconhecendo eles que seria extremamente difícil, senão impossível, para Portugal "resistir à terrível pressão do imperador dos franceses" $" 11$.

A família real saiu do porto de Lisboa em 29 de novembro de 1807, escoltada pela divisão naval do almirante inglês Sir Sidney Smith. Abatida por uma tempestade na travessia atlântica, a comitiva foi forçada a

${ }^{10}$ OLIVEIRA LIMA, Manuel de. D. João VI no Brasil. $4^{\mathrm{a}}$ ed. Rio de Janeiro: Topbooks, 2006. P. 43.

${ }^{11}$ OLIVEIRA LIMA, Manuel de. D. João VI no Brasil. P. 50. 
permanecer na Bahia por algum tempo, período em que foi decretada a famosa "abertura dos portos", que se explica a fundo no capítulo seguinte.

Após o breve desvio, a Corte chegou ao Rio de Janeiro em 7 de março de $1808^{12}$, momento em que se iniciou o árduo processo de adaptação da colônia, que, de rincão isolado a mando de Portugal, passava a constituir a "capital de um império à escala mundial"13 — e mais: residência do único monarca das Américas. Logo nos primeiros dias, notouse a brutal diferença entre a metrópole e o além-mar:

O Brasil era um mosaico de províncias, cada qual tendo seu aspecto particular, mas ligadas pela identidade da raça, da língua e da religião, de maneira que o conjunto oferecia uma admirável harmonia. A autoridade real estendia-se sobre todo o imenso território, e ligava entre si suas várias divisões, subordinando-as à mesma direção ${ }^{14}$.

D. João VI se propôs rapidamente a encabeçar o movimento de modernização e desenvolvimento da colônia, promovendo extensas reformas de instituições vigentes e criando inúmeras outras. O período que ficou conhecido como o das Reformas Joaninas viu o nascimento da Imprensa Régia, do Banco do Brasil e da Biblioteca Real, dentre outros; além disso, criaram-se tribunais para administrar a justiça e permitiu-se o livre exercício de qualquer tipo de indústria, revogando-se o Alvará de $1785^{15}$.

A rápida expansão do valor político da colônia e a abertura dos portos aos navios britânicos possibilitaram a viagem de muitos estrangeiros ao Brasil, que traziam consigo notícias, livros, máquinas e ideais nunca

\footnotetext{
${ }^{12}$ ARMITAGE, John. História do Brasil: desde o período da chegada da família de Bragança, em 1808, até a abdicação de D. Pedro I, em 1831. 1ª ed. Brasília: Senado Federal, 2011. P. 50 e 51.

${ }^{13}$ SILVA, Maria Beatriz Nizza da (Coord.). O Império Luso-Brasileiro (1750-1822). $1^{\text {a }}$ ed. Lisboa: Estampa, 1986. P. 383.

${ }_{15}^{14}$ OLIVEIRA LIMA, Manuel de. Formação histórica da nacionalidade brasileira. P. 151 e 152.

${ }^{15}$ ARMITAGE, John. História do Brasil. P. 51.
} 
antes vistos pelo povo local. Esse fator, para além do crescimento comercial, foi de suma importância para o desenvolvimento intelectual da elite brasileira, que foi subitamente posta em contato com o "farto elemento estrangeiro" $" 16$.

A estrutura administrativa do governo metropolitano foi transplantada ao Brasil, tudo com vista a gerar a menor disparidade possível na gestão do território. Desse modo, recriaram-se o Conselho de Estado, o Real Erário - posteriormente Ministério da Fazenda - e o Desembargo do Paço, além do ministério do Reino e o da Marinha e Ultramar. Essa reestruturação, contudo, foi feita

à revelia da Colônia, sobrepondo-se a ela de maneira impositiva, quase não incorporando os próprios colonos, visto que havia a preocupação de absorver toda a nobreza parasitária, que contava com milhares de pessoas e havia fugido junto com o Regente. Era um governo totalmente fora da realidade social do país. (...) As entidades e repartições públicas se multiplicavam e mantinham-se distantes das necessidades sociais ${ }^{17}$.

As dificuldades financeiras do novo governo, causadas pelo fechamento dos portos da Europa napoleônica e pela quase inexistência de manufaturas, causaram alarme no monarca. A solução encontrada para suprir os mercados português e britânico, isolados e aliados, foi o Tratado de Comércio Anglo-Lusitano de 1810. Ao conceder taxas de importação ad valorem favoráveis aos britânicos, o diploma propiciou o escoamento das suas mercadorias manufaturadas, até então imobilizadas pelo bloqueio continental $^{18}$.

\footnotetext{
${ }^{16}$ SILVA, Maria Beatriz Nizza da (Coord.). O Império Luso-Brasileiro. P. 80.

${ }^{17}$ CASTRO, Flávia Lages de. História do direito: geral e Brasil. $8^{\mathrm{a}}$ ed. Rio de Janeiro: Lumen Juris, 2011. P. 325 e 326.

${ }^{18}$ FAUSTO, Boris; HOLANDA, Sergio Buarque de. O Brasil monárquico: o processo de emancipação. P. 101.
} 
Em termos de política financeira, o governo joanino objetivava centralizar a arrecadação de verbas, substituindo um sistema tributário defeituoso e ineficaz por um aparato coordenado diretamente pela ação do príncipe regente. Foi com esse intuito que se criaram: a "décima urbana", imposto de $10 \%$ (depois de 20\%) sobre o valor locativo dos imóveis; o imposto de exportação, esvaziado pelas abundantes isenções concedidas; a "décima de heranças e legados"; a "sisa dos bens de raiz"; e a "meia sisa dos escravos" $" 19$.

O estabelecimento do Desembargo do Paço no Rio de Janeiro pouco fez para coibir as condutas autoritárias praticadas a título de "justiça" na colônia. Muitos dos abusos cometidos rotineiramente pelas milícias de justiceiros particulares, em resposta à morosidade e à ausência do sistema judiciário, foram relatados pelo Correio Braziliense:

Ora são dívidas mandadas pagar entre partes por execução militar, sem processo judicial; ora um indivíduo mandado prender por ter movido a outro um pleito em justiça; ora uma câmara municipal repreendida e desautorada por haver representado contra uma nomeação do governador. (...) À parte prejudicada restava intentar ação de perdas e danos, que era sempre - então mais ainda do que hoje - um processo difícil, dispendioso e de resultados problemáticos. Não se deveriam entretanto qualificar de crimes privados, antes de crimes públicos, "excessos de jurisdição", que abrangiam prisão, sequestro e quejandas violências ${ }^{20}$.

A nova administração tentou de tudo para mudar o estado semianárquico das relações jurídicas no Brasil. Elevou o Tribunal da Relação do Rio de Janeiro ao status de Casa de Suplicação, órgão tradicional presidido pelo monarca, e estabeleceu juntas locais para melhor organizar a estrutura de julgamento dos processos judiciais, buscando com

${ }^{19}$ FAUSTO, Boris; HOLANDA, Sergio Buarque de. O Brasil monárquico: o processo de emancipação. P. 103 e 104.

${ }^{20}$ OLIVEIRA LIMA, Manuel de. D. João VI no Brasil. P. 470. 
isso proporcionar o melhor acesso à, e distribuição da, justiça e moderar a "tirania dos governadores" $"$.

As estratégias empregadas para regularizar a aplicação da justiça em território brasileiro, ainda que bem intencionadas, não obtiveram sucesso; viram-se confrontadas pelas tradições violentas da colônia, já cristalizadas pelo peso dos séculos. A vagarosidade do aparato judicial, a sua persistente dificuldade de acesso e a corrupção dos agentes públicos que o integravam acabaram por gerar um forte sentimento de desconfiança na população, de modo que as mudanças e reformas judiciárias surtiram pouco efeito, ao menos até a outorga da Constituição de 1824.

A consolidação do governo lusitano no Brasil criou uma situação até então inédita no cenário internacional imperialista: uma metrópole sem governo e uma colônia que era residência do soberano. A grande comitiva que acompanhou a família real teve que ser integrada ao sistema administrativo, causando atritos com os habitantes locais. De fato, sabe-se que "a rivalidade sempre prevaleceu entre os portugueses e brasileiros natos, e esse procedimento da parte do Governo português tendia a aumentá-la" 22 .

A confusão institucional se manteve por sete anos, ao longo dos quais a inversão da importância de Portugal e Brasil se tornou cada vez mais acentuada. Isso desagradou fortemente aos habitantes europeus do império luso, que, abandonados à própria sorte e distantes da administração central, se viam preteridos pelo monarca em favor do que era, pouco tempo atrás, apenas uma colônia.

Foi somente em 1815 que D. João VI resolveu agir para regularizar a incomum situação jurídica do Império. Reconhecendo que o Brasil não

\footnotetext{
${ }^{21}$ OLIVEIRA LIMA, Manuel de. D. João VI no Brasil. P. 471.

${ }^{22}$ ARMITAGE, John. História do Brasil. P. 52.
} 
mais sustentava as características típicas de uma colônia — "daqui saíam as decisões que interferiam em todos os domínios portugueses, mesmo no território da antiga metrópole" 23 — decidiu, por meio da Carta de Lei de 16 de dezembro de 1815, torná-lo também Reino, a exemplo de Portugal e Algarves. Dispunha esse diploma legal que,

dando ao mesmo tempo a importancia devida a vastidão e localidade dos meus dominios da America, a copia e variedade dos preciosos elementos de riqueza que elles em si contém: e outrosim reconhecendo quento [sic] seja vantajosa aos meus fieis vassallos em geral uma perfeita união e identidade entre os meus Reinos de Portugal, e dos Algarves, e os meus Dominios do Brazil (...) sou portanto servido e me praz ordenar o seguinte: I. Que desde a publicação desta Carta de Lei o Estado do Brazil seja elevado a dignidade, preeminencia e denominação de Reino do Brazil. II. Que os meus Reinos de Portugal, Algarves e Brazil formem d'ora em diante um só e unico Reino debaixo do titulo: Reino Unido de Portugal e do Brazil e Algarves ${ }^{24}$.

A elevação do status jurídico do Brasil causou muito desconforto em Portugal, pois se acreditava que a formalização da maior autonomia brasileira, e até a sua preponderância como centro da ação política imperial, poderia impedir sua eventual regressão à condição colonial. As tentativas então feitas pelo governo para aliviar os descontentamentos em Portugal "foram vistas pelos Brasileiros como disfarçadas tentativas de subjugação" 25 .

Amadurecia a inimizade entre os dois principais polos do império; logo irromperia o conflito. Conforme explica Raymundo Faoro, jurista, procurador do Estado da Guanabara e historiador brasileiro, "na medida em que as duas frações — a metrópole e a colônia — não mais se entendem em

${ }^{23}$ CASTRO, Flávia Lages de. História do direito. P. 339 e 340.

24 PORTUGAL. Carta de Lei de 16 de dezembro de 1815. Disponível em http://www2.camara.leg.br/legin/fed/carlei/anterioresa1824/cartadelei-39554-16-dezembro-1815569929-publicacaooriginal-93095-pe.html. Acesso em 16.08.2018.

${ }^{25}$ SILVA, Maria Beatriz Nizza da (Coord.). O Império Luso-Brasileiro. P. 384. 
termos de estrita dependência, o velho divórcio das sociedades produzira os frutos explosivos da separação"26.

\subsection{Ruptura e crise institucional: $1815-1821$}

Sabeis bem que o vocábulo democracia tem uma única etimologia, mas que pode variar infinitamente de sentido. A democracia portuguesa de então não brilhava pela tolerância nem pelo espírito de justiça. (...) Lisboa não podia resignar-se à situação de uma capital decaída, privada do melhor de seu comércio transatlântico, profundamente atingida nos seus rendimentos e, por consequência, no seu luxo. Foi assim que ciúme para com o país de além-mar fez tanto, senão mais, pelo levante, quanto as fascinações das ideias novas ${ }^{27}$.

A inversão valorativa que se operou entre colônia e metrópole nos primeiros anos de D. João VI no Rio de Janeiro causou extrema insegurança social, pois desconstituiu subitamente uma ordem já propagada por séculos e mantida, em grande parte, pelos proprietários de terras. A introdução da autoridade metropolitana dentro do território brasileiro obscureceu as relações de poder outrora estabelecidas, gerando vácuos que tendiam a ser preenchidos pelos agentes da independência.

As províncias do norte e do nordeste do Brasil não compartilharam do enriquecimento financeiro e intelectual do qual se beneficiou o Rio de Janeiro, estando distantes demais para participar dos processos deflagrados pela chegada da Corte. O governo, desprovido de riquezas e preso ao Tratado de Comércio Anglo-Lusitano de 1810, não podia aumentar o imposto de importação. Como solução, onerou principalmente as produções de açúcar e algodão, o que repercutiu pesadamente em Pernambuco e suscitou insatisfação geral.

\footnotetext{
${ }^{26}$ FAORO, Raymundo. Os donos do poder. P. 300.

${ }^{27}$ OLIVEIRA LIMA, Manuel de. Formação histórica da nacionalidade brasileira. P. 172.
} 
De fato, a inconsistência do desenvolvimento econômico brasileiro no período joanino se deveu muito às amarras diplomáticas e fiscais que ligavam o país ao Reino Unido. Celso Furtado explica que os problemas entre a elite local e os comerciantes britânicos não eram de matriz puramente econômica, mas "resultavam principalmente da falta de coerência com que os ingleses seguiam a ideologia liberal"28. A divisão classista que esse sistema criou na sociedade brasileira era ainda mais evidente dentro das províncias, onde apenas os ricos proprietários de terras podiam rivalizar politicamente com os mercadores.

Ficava claro que a conjuntura de um império luso-brasileiro era insustentável; havia ainda muitas disparidades entre a Corte e as províncias, e nenhum interesse político em abrandá-las. Na visão dos súditos do interior, o Rio de Janeiro representava fidedignamente a antiga metrópole: "o ressentimento nativista concluiu que Lisboa já não estava em Lisboa, mas no Rio" ${ }^{29}$. Na ótica do governo, ao contrário, as demais províncias constituíam "um simples setor, embora o essencial, daquela grande empresa comercial que é a monarquia portuguesa, com o seu rei no balcão",30.

O primeiro grande sinal de instabilidade do regime foi a revolta de Pernambuco em 1817. Formada de uma união improvável de elementos rurais e mercantis, aliciados pela maçonaria local e seus ideais iluministas, ela representou "o descontentamento fluido de muitas categorias, soldados, comerciantes e sobretudo dos agricultores"31. Os diversos grupos insurgentes eram liderados, dentre outros, por Antonio Carlos Ribeiro de

\footnotetext{
${ }^{28}$ FURTADO, Celso. Formação econômica do Brasil. 17a ed. São Paulo: Ed. Nacional, 1980. P. 95.

${ }^{29}$ MELLO, Evaldo Cabral de. A outra Independência: o federalismo pernambucano de 1817 a 1824. $2^{\text {a }}$ ed. São Paulo: Editora 34, 2004. P. 35

${ }^{30}$ PRADO JR, Caio. Formação do Brasil contemporâneo. $1^{a}$ ed. São Paulo: Companhia das Letras, 2011. P. 385.

${ }^{31}$ FAORO, Raymundo. Os donos do poder. P. 302.
} 
Andrada $^{32}$ e pelo Frei Caneca; suas irritações se voltavam principalmente contra os comerciantes portugueses, favorecidos por novas taxas comerciais, e contra a Corte, que exercia sobre Pernambuco um sufocante domínio fiscal e jurídico.

Avançando sobre o governo estabelecido da província em 6 de março de 1817, os revoltosos chegaram rapidamente ao sucesso com a rendição do governador, submetendo-se-lhes todas as demais autoridades locais sem muito desgaste. Apesar de desenvolvida e implementada por maçons adeptos do iluminismo francês, a sublevação não propunha, ao menos de pronto, a proclamação de uma república pernambucana e a formalização dos direitos dos cidadãos. $\mathrm{Na}$ verdade, os elementos republicanos e monarquistas se alternavam dentro do movimento; tanto que a junta de governo então formada considerou abrir "negociações com El Rei para solicitar a redução de impostos e o estabelecimento de limites ao poder dos governadores",33.

A revolta pernambucana acabou tão subitamente quanto começou. Logo em meados de abril, o governo central instaurou um bloqueio naval à província, que, aliado a um corpo militar terrestre sob as ordens do general Luís do Rego Barreto, foi bem-sucedido em promover a rendição dos insurgentes até o mês de junho ${ }^{34}$. Quando chegou ao Rio de Janeiro, a notícia do fim da revolta "foi acolhida com foguetes, repiques de sinos e iluminações gerais" $" 35$.

\footnotetext{
32 "Foi um astro luminoso, que se afundou nas cores do poente; um nome glorioso, que a História conquistou para suas páginas. Sua figura gigante avulta no pórtico da Independência, como um dos criadores de nossa nacionalidade. (...) Enquanto houver um culto pelos grandes homens, e a virtude cívica inspirar a gratidão, o Brasil inteiro repetirá com religioso respeito o nome de Antônio Carlos, que irá abrindo um sulco luminoso através dos séculos futuros" (SISSON, Sébastien Auguste. Galeria dos brasileiros ilustres. 1ª ed. Brasília: Senado Federal, 1999. V1. P. 281).

${ }^{33}$ MELLO, Evaldo Cabral de. A outra Independência. P. 40.

${ }^{34}$ OLIVEIRA LIMA, Manuel de. D. João VI no Brasil. P. 510

${ }^{35}$ OLIVEIRA LIMA, Manuel de. D. João VI no Brasil. P. 515.
} 
Conquanto breve, a revolta de Pernambuco representa um episódio determinante na história política brasileira: foi o primeiro movimento que uniu burgueses, agricultores, maçons, militares e eclesiásticos contra a administração central da dinastia portuguesa. A sua rápida derrocada, porém, revelou a inconstância da sua gestão, sempre às voltas com discussões sobre sistemas de governo e ideais políticos. Na verdade, ainda que os revoltosos não tivessem "nenhuma intenção de alterar as estruturas sociais" "36 " "ensaio geral" de 1817 fixou as bases sobre as quais se mobilizaria a Independência.

O fim das guerras napoleônicas em 1815 permitiu o estabelecimento de uma nova ordem política na Europa. Os princípios da legitimidade e do equilíbrio dos poderes, estipulados no Congresso de Viena, foram os pontos de partida para a reconstrução institucional dos países que haviam sido abalados pelo expansionismo francês. A permanência do monarca e de sua Corte no Brasil nessas circunstâncias irritou os habitantes de Portugal, que, como exposto, já se viam desfavorecidos na conjuntura do império. Para além disso, a abertura dos portos foi explorada "como a causa da completa aniquilação, tanto das fábricas como do comércio de Portugal"37.

Tomando o exemplo de Espanha e Itália, o povo português se mobilizou inicialmente no Porto em 24 de abril de 1820, exigindo a convocação de cortes populares para que se constitucionalizasse a política lusitana. A sublevação se instaurou em Lisboa em 15 de setembro do mesmo ano, com a deposição dos regentes, marcando-se a primeira sessão geral das cortes para janeiro de $1821^{38}$. O movimento, a exemplo do que seria a Independência brasileira, "não teve caráter popular, não modificou a estrutura social, não reformou as relações sociais. Foi um golpe da

\footnotetext{
${ }^{36}$ SILVA, Maria Beatriz Nizza da (Coord.). O Império Luso-Brasileiro. P. 385.

${ }^{37}$ ARMITAGE, John. História do Brasil. P. 61.

${ }^{38}$ ARMITAGE, John. História do Brasil. P. 61.
} 
burguesia portuguesa, promovido pelos negociantes, fomentado pela Maçonaria e pelas ideias liberais"39.

Os ideais das Cortes de Lisboa, posto que aglutinados entre grupos heterogêneos, continham uma contradição fundamental. Se de um lado, as Cortes buscavam a constitucionalização do regime e a concessão de liberdades pessoais ao povo, por outro agiam de forma reacionária e colonialista, tudo no intuito de resgatar a importância perdida para o Brasil e submetê-lo, novamente, à sua exclusiva jurisdição. Assim, parte dos seus debates foi dedicada a esse tema.

Inicialmente compostas apenas de portugueses da metrópole, as Cortes foram palco de amplas discussões acerca de liberdades individuais e das condições do império marítimo, sendo preponderante nesses temas o status jurídico do Brasil ${ }^{40}$. Talvez o mais célebre deputado brasileiro nessa assembleia tenha sido Antonio Carlos Ribeiro de Andrada, que, após o fracasso da revolta de 1817, punha-se novamente no cenário político nacional, buscando obter maior autonomia para o Brasil e, em especial, para as suas províncias.

A subjugação política que para os brasileiros constituía medida intragável era, não obstante o "orgulho metropolitano"41 dos portugueses, resultante da aplicação do liberalismo econômico que norteava a ação dos países europeus após o Congresso de Viena. Assim, as grandes disposições das Cortes de Lisboa sobre o Brasil se detinham mais na instituição do livre comércio, sustentado pelas produções internas de todas as partes do império

\footnotetext{
${ }^{39}$ RODRIGUES, José Honório. Independência: revolução e contra-revolução: a evolução política. P. 69.

${ }^{40}$ ROCHA, Antonio Penalves. A Recolonização do Brasil pelas Cortes: história de uma invenção historiográfica. $1^{\text {a }}$ ed. São Paulo: Unesp, 2009. P. 87.

${ }^{41}$ MARQUES, Xavier. Ensaio histórico sobre a Independência. $2^{\mathrm{a}}$ ed. Rio de Janeiro: Instituto Nacional do Livro, 1977. P. 66.
} 
indistintamente, do que nas proibições típicas de um pacto colonial. Nenhuma deliberação fantasiosa das Cortes, porém, faria frente à realidade:

O que efetivamente contava é que havia autonomia econômica, crescimento econômico e um reino brasileiro. Enfim, os efeitos de todas as medidas de D. João VI inviabilizavam de fato a volta do Brasil à condição de colônia, pois as mudanças que provocaram foram enredadas numa teia de interesses econômicos, políticos e diplomáticos, tecida por ingleses, brasileiros, monarquia portuguesa e monarquias europeias. (...) Nesse contexto, os resultados inesperados das disposições [das Cortes] — ou a "natureza das coisas", segundo Silvestre Pinheiro - ergueram obstáculos intransponíveis para o efetivo restabelecimento do exclusivo ${ }^{42}$.

Para além das projeções liberais e colonialistas, a convocação das Cortes tinha o objetivo primário de constitucionalizar o regime político lusitano. Para isso, tencionava a integração da monarquia tradicional às correntes jurídicas da época. Influenciadas pela Revolução Francesa "estranho caos de leviandade e ferocidade" $" 43$ _, as Cortes pregavam a soberania nacional desvinculada do monarca e a separação de poderes, prevendo também o direito de propriedade e as liberdades de imprensa e de indústria.

Apesar da dificuldade prática de concretizar as medidas tramadas pelas Cortes, a chegada de notícias a esse respeito ao território brasileiro causava atritos já no início de 1821, principalmente nas províncias do norte e do nordeste. A pendência de uma Constituição proclamada à revelia do rei, unida à possibilidade de correspondentes insurreições dentro do Brasil, gerou nervosismo em D. João VI. Foi desse modo que se viu forçado, em 26 de fevereiro de 1821, a jurar a constituição que estava sendo redigida

\footnotetext{
${ }^{42}$ ROCHA, Antonio Penalves. A Recolonização do Brasil pelas Cortes. P. 114 e 115.

${ }^{43}$ BURKE, Edmund. Reflexões sobre a Revolução em França. $1^{\mathrm{a}}$ ed. Brasília: Ed. UNB, 1982. P. 52.
} 
pelas Cortes. Assim, "ainda longe de tornar-se efetivo, e sobretudo uniforme, o novo regime tornou-se oficial para todo o Brasil"44.

Encerrava-se, com efeito, o período joanino no Brasil; apesar dos esforços do rei português, o balanço era negativo. Nomeando D. Pedro como regente e partindo para Portugal em abril de 1821, deixava para trás um povo inquieto, um sistema jurídico vacilante e uma clamorosa desigualdade financeira. Sobre o legado de D. João VI, não há dúvidas de que "fora impelido pelo medo, e, pelo medo, à pátria regressava. Sua Regência em Portugal resultara na ocupação do país; sua Regência e Reinado no Brasil, na perda da colônia" ${ }^{45}$. Sob a flâmula de D. Pedro "paladino do constitucionalismo"46 — se ergueria, enfim, a "fúria contagiosa" 47 da revolução de Independência.

\subsection{A reação nacional: $1821-1822$}

A cisão da sociedade colonial e do povo brasileiro é irreparável. (...) O meio social, com a mesma força transmutadora do meio físico, apropria e converte em agentes da revolução a muitos daqueles que se orgulhavam de bons e leais portugueses. D. João VI, acossado pelas tropas de Junot, veio lançar no terreno já aparelhado as instituições fundamentais do regime livre. Os revolucionários do Porto, solicitando o nosso apoio, reconhecem-nos implicitamente o direito à liberdade. (...) A independência subia do seio do povo, suscitando e elegendo os seus arautos entre brasileiros e portugueses, indistintamente ${ }^{48}$.

Em 27 de abril de 1821, apenas um dia depois da partida de seu pai a Portugal, D. Pedro I mostrou seu lado estadista. Proclamou aos brasileiros

\footnotetext{
44 FAUSTO, Boris; HOLANDA, Sergio Buarque de. O Brasil monárquico: o processo de emancipação. P. 159.

${ }^{45}$ RODRIGUES, José Honório. Independência: revolução e contra-revolução: a evolução política. P. 169.

${ }^{46}$ BITAR, Orlando. Missão constitucional de Pedro I. In:___. Obras completas de Orlando Bitar: estudos de Direito Constitucional e Direito do Trabalho. $1^{\mathrm{a}}$ ed. Rio de Janeiro: Renovar, 1996. v2. P. 327.

${ }^{47}$ CONSTANT, Benjamin. Princípios de política aplicáveis a todos os governos. P. 665.

${ }^{48}$ MARQUES, Xavier. Ensaio histórico sobre a Independência. P. 27 e 28.
} 
que respeitaria as leis estabelecidas, privilegiando a educação pública, a agricultura e o comércio; tudo no intuito de tranquilizar a população acerca da instabilidade vigente nos dois lados do Atlântico e aumentar a confiança do povo no seu novo governante. Enquanto foi regente do Brasil, o futuro Imperador se voltou para assuntos de fundamental importância econômica e social, estipulando a desoneração de tributos, a garantia do direito de propriedade e a presunção de inocência.

A aparente generosidade de D. Pedro I tinha clara aspiração política, voltando-se a unificar os interesses das classes dominantes contra a ameaça externa. O problema foi que, "como sempre, o liberalismo só atingia os livres, não os escravos, mas para os brasileiros livres, sofrendo os abusos do absolutismo, as medidas eram sensacionais" $" 49$.

As atitudes empreendidas pelo governo do regente refletiam um dos maiores obstáculos, até hoje, para a consolidação da nacionalidade brasileira: a clara e aberrante falta de isonomia real entre os cidadãos mesmo entre os livres —, não obstante as garantias formais positivadas pelos bem-intencionados legisladores iluministas. Ao tratar do princípio da igualdade inserido no ordenamento constitucional, Celso Antônio Bandeira de Mello entende que nem toda discriminação lhe causa dano necessariamente; é preciso "indagar quais as discriminações juridicamente intoleráveis" $"$. Nessa seara, vê-se que a escravidão, elemento máximo da discrepância social, servia de base (e até hoje serve) à flagrante quebra de isonomia, posto que traz desigualdade de tratamento sem que haja vínculo

\footnotetext{
${ }^{49}$ RODRIGUES, José Honório. Independência: revolução e contra-revolução: a evolução política. P. 172.

${ }^{50}$ BANDEIRA DE MELLO, Celso Antônio. Conteúdo jurídico do princípio da igualdade. $3^{\mathrm{a}}$ ed. São Paulo: Malheiros, 1993. P. 11.
} 
de correlação lógica entre essa os “interesses prestigiados na Constituição" 51 .

De fato, o príncipe regente estava tentando remediar os males e manter a unidade do território brasileiro, já bastante abalado pela revolta da Bahia, iniciada em 10 de fevereiro de 1821. Os baianos, liderados por Cipriano Barata, haviam instalado uma junta provisória de governo e jurado as bases da Constituição portuguesa, negando o reconhecimento da autoridade de D. Pedro I. Temendo uma retaliação pelo governo do Rio de Janeiro, os rebeldes solicitaram apoio militar lusitano, o que foi prontamente concedido pelas Cortes.

A presença militar na Bahia, representada pelo General Inácio Luís Madeira de Melo, encontrou forte resistência, a despeito de ter sido requerida pela junta provisória. A posição do Rio de Janeiro logo se fez clara: longe de buscar a submissão da província pela força, conclamava aos cidadãos baianos que lutassem pela união nacional e contra o controle absoluto das Cortes, "não obstante parecerem fazer o jogo de Lisboa"52.

As lealdades no território brasileiro estavam erodindo, e o antigo jogo de poder, se reorganizando. Buscando esclarecer quem seria o verdadeiro governante no Brasil, não obstante o caráter representativo da regência de D. Pedro I, uma tropa lusitana no Rio de Janeiro se reuniu e forçou o regente a jurar as bases da futura constituição portuguesa, tal qual havia acontecido com D. João VI.

A truculência dos soldados portugueses nas províncias, aliada às medidas centralizadoras e autoritárias promulgadas pelas Cortes, serviu para propagar o sentimento antilusitano no Brasil. Não era propriamente um

\footnotetext{
${ }^{51}$ BANDEIRA DE MELLO, Celso Antônio. Conteúdo jurídico do princípio da igualdade. P. 17. 52 OLIVEIRA LIMA, Manuel de. O movimento da Independência: 1821-1822. $6^{\mathrm{a}}$ ed. Rio de Janeiro: Topbooks, 1997. P. 67.
} 
chamado à independência, posto que esse processo vinha ocorrendo desde 1808 , faltando "consolidá-la com a monarquia brasileira e constitucional"53. De meados ao fim de 1821, a revolta popular pregava uma solução conjunta, mas com autonomia para ambas as partes do império lusitano, como se depreende de um poema que circulou no Rio de Janeiro nessa época, assinado "por um amante da pátria":

$\begin{array}{ll}\begin{array}{l}\text { Se queres ainda Reinar, } \\ \text { Olha beato João, } \\ \text { Deves ir para Portugal, } \\ \text { E assinar a constituição. }\end{array} & \begin{array}{l}\text { Assina a Constituição } \\ \text { Não te faças singular, } \\ \text { Olha que a teus vizinhos } \\ \text { Já se tem feito assinar }\end{array} \\ \begin{array}{l}\text { Se tu depressa não vais } \\ \text { Para o teu país natal, }\end{array} & \begin{array}{l}\text { Isto não só é bastante, } \\ \text { Ó João olha que perdes }\end{array} \\ \begin{array}{l}\text { Deves deixar o Brasil, } \\ \text { (...) }\end{array} & \text { Se não virás em breve } \\ & \text { A sofrer desgostos mil. } \\ & (\ldots)^{54}\end{array}$

A opinião pública brasileira estava, portanto, dividida em três polos complementares e antagônicos: o Rio de Janeiro, sede do governo, da alta cultura e dos mais influentes comerciantes do país; Pernambuco, ainda marcado pela revolta de 1817 , que propunha uma independência radical com o estabelecimento de uma república; e a Bahia, que alternava entre rompantes de nacionalismo lusitano e defesas do constitucionalismo brasileiro.

As posições demasiado duras dos grupos dominantes em Pernambuco terminaram por isolar a província das negociações que estavam sendo feitas pelo país. A junta provisória estabelecida na Bahia foi derrubada rapidamente, tornando-se preponderante o partido dinástico, que

\footnotetext{
53 FAUSTO, Boris; HOLANDA, Sergio Buarque de. O Brasil monárquico: o processo de emancipação. P. 156.

54 CARVALHO, José Murilo de et al (Org.). Às armas, cidadãos!: panfletos manuscritos da Independência do Brasil (1820-1823). $1^{\text {a }}$ ed. Rio de Janeiro: Companhia das Letras e Editora Ufmg, 2012. P. 169 e 170.
} 
"contentava-se com a independência monárquica e para a separação marchava, através de confraternizações efêmeras e condescendências com os dominadores" $" 55$. Assim é que se construiu o eixo Salvador-Rio de Janeiro, a união das duas capitais históricas que seria fundamental na consolidação do movimento pela independência do país.

A liderança baiana, sob a ameaça militar do General Madeira, propunha de início uma composição amigável, utilizando para isso o exemplo dos delegados enviados às Cortes de Lisboa. O Diário Constitucional, periódico publicado na cidade de Salvador a partir de 4 de agosto de 1821, expunha contrariamente que, não importando como viesse a ser feita a separação política, "é mais do que claro que o Brasil necessita de legislação própria, por ventura em muitos respeitos diferente da que convém a Portugal" $" 56$.

Esse jornal, criado por Francisco Jê Acaiaba de Montezuma futuro deputado constituinte e fundador do Instituto dos Advogados do Brasil —, se propunha a derrubar a junta de governo favorável aos portugueses, estreitando a lealdade do povo baiano com o governo independente do Rio de Janeiro. Foi assim que, transmutando o jogo de forças políticas na Bahia, o periódico se tornou sinônimo de resistência ao partido português e às determinações das Cortes. O General Madeira, escrevendo à junta de governo sobre a atuação do veículo em junho de 1822, dizia:

Assim tornam-se do maior perigo os escritos que se publicaram dirigindo a opinião pública de uma maneira própria para produzir a anarquia e guerra civil, e é por isso que o n. 25 do Constitucional, proclamando aos povos para se unirem

\footnotetext{
${ }^{55}$ MARQUES, Xavier. Ensaio histórico sobre a Independência. P. 93.

56 "No 31, 27.03.1822", apud SILVA, Maria Beatriz Nizza da. Diário Constitucional: um periódico baiano defensor de D. Pedro - 1822. $1^{\text {a }}$ ed. Salvador: Ed. UFBA, 2011. P. 61.
} 
ao Rio de Janeiro, é incendiário e seus autores perturbadores da ordem estabelecida $^{57}$.

Em dezembro de 1821, as Cortes de Lisboa emitiram um decreto no qual ordenavam o retorno do regente a Portugal, medida inserida no grande plano de despojar o Brasil de sua autonomia recém-conquistada. Frente a essa determinação, até os grupos mais moderados ficaram atônitos. Houve larga manifestação de brasileiros, e mesmo de portugueses que moravam no país, contra a ordem das Cortes, pois "não viam na retirada do príncipe senão dissolução, anarquia e saqueio geral" ${ }^{\text {"58 }}$.

Mais do que a ineficácia das propostas feitas pelos delegados brasileiros em Portugal, foi o autoritarismo das Cortes quanto à permanência ou não do príncipe regente no Brasil que alertou as lideranças políticas do país para o projeto intransigente que viria a ser escrito. Em carta ao seu pai em 14 de dezembro de 1821, D. Pedro I escrevia que o povo se manifestou dizendo que "se a constituição é fazerem-nos mal leve o diabo tal coisa; havemos fazer um termo para o príncipe não sair, sob pena de ficar responsável pela perda do Brasil para Portugal"59.

A agitação popular foi tanta que se multiplicaram declarações, pelas Câmaras Municipais, pelo Senado da Câmara e por grupos de comerciantes, pedindo a manutenção do governo do regente. Agindo de forma ponderada e encorajado por um manifesto político dotado de mais de oito mil assinaturas, D. Pedro I manifestou a sua permanência por meio de José Clemente Pereira, notório maçom e Presidente do Senado da Câmara.

\footnotetext{
57 “No 42, 15.07.1822”, apud SILVA, Maria Beatriz Nizza da. Diário Constitucional. P. 150.

58 VARNHAGEN, Francisco Adolpho de. História da independência do Brasil: até ao reconhecimento pela antiga metrópole, compreendendo, separadamente, a dos sucessos ocorridos em algumas províncias até essa data. $1^{\text {a }}$ ed. Brasília: Senado Federal, 2010. P. 107.

${ }^{59}$ OLIVEIRA LIMA, Manuel de. O movimento da Independência. P. 185.
} 
Não obstante a imprecisão da data — se em 9 ou em 10 de janeiro de 1822 — , suas palavras se tornaram célebres e serviram de fundamento moral para a iminente separação. No episódio que ficou conhecido como "Dia do Fico", o futuro Imperador se manifestou: "como é para o bem de todos e a felicidade geral da nação, diga ao povo que fico" ${ }^{\text {60 }}$. A adesão de Pernambuco veio logo depois, em 21 de janeiro.

Constatada a impossibilidade da união e tornada pública a resistência do regente às Cortes, decidiu-se formar um novo Ministério, liderado por José Bonifácio de Andrada e Silva - que, assumindo em 19 de janeiro, ficou depois conhecido como o Patriarca da Independência. Pondo-se a viajar pelo país para aglutinar os interesses dos diversos grupos por ele espalhados, D. Pedro I mostrou toda a sua desenvoltura frente às contradições fundamentais do regime que buscava instituir.

Sobre a tradição monárquica agirá a mensagem liberal, conjugadas na pessoa do "jovem herói" que sabia por sua vez combinar atrevimento e habilidade, seduzir as imaginações e conciliar fidelidade onde havia prevenção ou dissidência. Demonstrou-o logo na viagem a Minas (abril), como depois na excursão culminante a São Paulo, apalpando primeiro o terreno, enfrentando elementos suspeitos ou descontentes e triunfando numa onda de simpatia ${ }^{61}$.

A irredutibilidade da posição portuguesa a respeito da autonomia brasileira conduziu à radicalização do movimento separatista no Brasil, visto como a única saída tangível para o domínio opressor operado pelas Cortes de Lisboa. Uma das formas de enfraquecer o jugo lusitano, representado inclusive militarmente, foi a de conceder baixas aos soldados e de realistá-los no Brasil, apelando para o sentimento nacionalista e

\footnotetext{
${ }^{60}$ RODRIGUES, José Honório. Independência: revolução e contra-revolução: a evolução política. P. 209.

${ }^{61}$ FAUSTO, Boris; HOLANDA, Sergio Buarque de. O Brasil monárquico: o processo de emancipação. P. 168.
} 
constitucionalista que muitos desses soldados já nutriam pelo país ${ }^{62}$. O Ministério de José Bonifácio constituiu, nesse período, um verdadeiro Conselho de Estado ao futuro Imperador, auxiliando no desenvolvimento e na aplicação das políticas de governo.

Atendendo a um pedido do Conselho de Procuradores das Províncias em 3 de junho de 1822 - como será visto adiante - D. Pedro I decretou a reunião de uma Assembleia Geral Constituinte e Legislativa, cujos membros seriam eleitos nas províncias. Ainda que prévia ao rompimento oficial, essa medida alertou os portugueses da irrefreável revolução que se desenhava, porquanto significava que o "Brasil já possuía por vontade da nação um arcabouço constitucional que Portugal não admitia e de que não cogitava sua constituição, a qual devera ser comum" ${ }^{\text {63. }}$.

A narrativa construída no Brasil face à postura das Cortes de Lisboa, principalmente depois da convocação da Assembleia, não deixava qualquer margem à composição amigável entre os países. A beligerância crescente entre os povos do império lusitano indicava que nada poderia ser feito até a deflagração de um confronto militar. Assim defendia um brasileiro em folheto anônimo da época:

O Brasil tem-se constituído em Império independente e separado - É pois da sua dignidade e para bem da sua conservação, que este Império repila a força com a força, e sufoque com maiores e mais prontas forças as de Portugal. Não há um momento que se não deva já aproveitar ${ }^{64}$.

Em agosto de 1822, o príncipe regente empreendeu viagem à província de São Paulo, onde era ainda necessário consolidar a opinião pública em torno de si. Por decreto do dia 13 desse mês, confiou a regência

\footnotetext{
${ }^{62}$ RODRIGUES, José Honório. Independência: revolução e contra-revolução: a evolução política. P. 227.

${ }^{63}$ OLIVEIRA LIMA, Manuel de. O movimento da Independência. P. 357.

${ }^{64}$ CARVALHO, José Murilo de et al (Org.). Às armas, cidadãos!. P. 174.
} 
à sua esposa, a Princesa Real D. Maria Leopoldina, ordenando ao Ministério e ao Conselho de Estado que procedessem como se o próprio D. Pedro I estivesse presente ${ }^{65}$.

Partindo com sua comitiva no dia seguinte, o futuro Imperador "já se despediu quase resolvido a declarar a independência"66. Passou, nos dias sucessivos, por Lorena, Guaratinguetá, Pindamonhangaba, Jacareí, Mogi das Cruzes, Penha e Santos; em todas essas cidades, angariou apoio popular, modulando seu ministério e fazendo alterações nos governos locais, tudo no intuito de garantir a adesão dos paulistas ao movimento que buscava concretizar.

Às margens do riacho do Ipiranga, em 7 de setembro de 1822, D. Pedro I declarou a Independência do Brasil. Com isso, iniciaram-se inúmeras dificuldades diplomáticas e jurídicas que serão tratadas adiante. Conforme alertado lugubremente por José Bonifácio, “todo governo em revolução só faz descontentes" ${ }^{\prime 67}$.

\footnotetext{
${ }^{65}$ BRASIL. Coleção das Leis do Império (1821-1830). Acesso em 29.10.2018.

${ }^{66}$ VARNHAGEN, Francisco Adolpho de. História da independência do Brasil. P. 157.

${ }^{67}$ ANDRADA E SILVA, José Bonifácio de. Projetos para o Brasil. P. 111.
} 


\section{O reconhecimento da Independência}

\subsection{Contexto político europeu e o papel do Reino Unido}

É claro que há sempre uma dimensão ideológica nesses governos que se pretendem expressão do "bem comum", e que no limite acabam por se empenhar em preservar o status quo. Não se trata de confundir ideologia e realidade, mas é evidente que há graus de identificação entre estado e camada dominante, e os momentos reformistas são exatamente aqueles em que esta relação se torna mais complexa: o estado, nessas situações, tende a ver além dos interesses da camada dominante, com vistas à própria preservação da estrutura de dominação ${ }^{68}$.

O processo de Independência do Brasil não deve ser considerado como um fenômeno social isolado. Se o rompimento político efetivamente gerou violentos conflitos dentro do território nacional, também se faz necessário avaliar as suas consequências externas. De fato, a declaração do dia sete de setembro de 1822 ocorreu em momento extremamente conturbado para as relações comerciais e diplomáticas em todo o mundo ocidental, tendo sobre elas relevante efeito.

Pode-se dizer, com alguma propriedade, que a primeira metade do século XIX foi um período de profundas transformações na ordem política global. Esse processo pode ser mais claramente visto nas sucessivas alternâncias de poder e ideologia, entre absolutistas e liberais, iniciado na Independência dos Estados Unidos da América em 1776, passando pela Revolução Francesa a partir de 1789 e se estendendo para atingir os impérios coloniais ibéricos. Eric Hobsbawm, historiador britânico, assim resume o período:

Após mais de vinte anos de guerras e revoluções quase ininterruptas, os velhos regimes vitoriosos enfrentaram os problemas do estabelecimento e da preservação da paz, que foram particularmente difíceis e perigosos. Os escombros de duas décadas tinham de ser varridos e a pilhagem territorial redistribuída. (...)

\footnotetext{
${ }^{68}$ NOVAIS, Fernando Antônio. Portugal e Brasil na crise do antigo sistema colonial: 1777-1808. $1^{a}$ ed. São Paulo: Hucitec, 1979. P. 302.
} 
Os reis e os estadistas não eram mais sábios nem tampouco mais pacíficos do que antes. Mas inquestionavelmente estavam mais assustados ${ }^{69}$.

A Europa ainda se recuperava das guerras napoleônicas, buscando a estabilização política e econômica prometida pelo Congresso de Viena de 1815. Essa viria pela restauração das monarquias absolutistas e aliadas, em oposição às pretensões democráticas ou republicanas das recentes revoluções burguesas - que logo surgiriam novamente.

O pensamento político europeu sofreu alterações pendulares nesse intervalo, oscilando entre o absolutismo e o liberalismo de forma imprevisível e até mesmo violenta. Após o primeiro momento de pânico, a união das elites rurais, do clero e da nobreza tradicional, com o apoio das cortes conservadoras, fez frente digna aos movimentos populares, prolongando a batalha ideológica na Europa e fora dela. Almeida Garrett, político e escritor português da época, traça em breves linhas o quadro geral do estado político do continente europeu e de seus satélites após a batalha de Waterloo:

O despotismo, a oligarquia triunfaram mais uma vez na Europa; a liberdade vacila na América... Estará perdida a causa dos povos, a causa da civilização? Não: cegueira dos seus inimigos, cobardia de seus fracos amigos o supõe: enganam-se. Derramemos a vista por essa parte da Europa e América a que damos com justiça o nome de 'mundo civilizado'. Vejamos se a submissão é perfeita, e duradoira essa paz de sepulcro ${ }^{70}$.

Com efeito, o diálogo das potências em Viena tinha por objetivo predominante a eliminação decisiva da fragilidade monárquica explorada pelos agentes da Revolução Francesa, evitando, dessa forma, o

\footnotetext{
${ }^{69}$ HOBSBAWM, Eric J. A era das revoluções: 1789-1848. 25a ed. São Paulo: Paz e Terra, 2011. P. 167 e 168.

${ }^{70}$ ALMEIDA GARRETT, João Baptista da Silva Leitão de. Portugal na balança da Europa: do que tem sido e do que ora lhe convém ser na nova ordem de coisas do mundo civilizado. $2^{\mathrm{a}}$ ed. Lisboa: Livros Horizonte, 2005. P. 49.
} 
aparecimento de grupos políticos com semelhantes ideais. Henry Kissinger, diplomata estadunidense, diz que a França era percebida, nesse contexto, de forma semelhante à Alemanha no século XX, ou seja, como "uma potência inerentemente desestabilizadora e cronicamente agressiva" ${ }^{\text {"71 }}$. Por isso, forjou-se, entre Áustria, Prússia, Rússia e Reino Unido, a Quádrupla Aliança, que teria por finalidade "cortar quaisquer tendências agressivas da França pela raiz com força esmagadora" 72 .

Não julgando ser tal pacto suficiente para conter as correntes nacionalistas e liberais na Europa, as três potências continentais (Áustria, Prússia, Rússia) assinaram um acordo adicional, proposto pelo Czar Alexandre I da Rússia, pelo qual se criava a Santa Aliança, instituição que visava manter os princípios absolutistas com viés precipuamente católico, condicionando sua atuação ao consenso entre seus membros.

A Santa Aliança reuniu os monarcas conservadores no combate às revoluções, mas também os obrigou a agir somente em conjunto, efetivamente dando à Áustria, um veto teórico sobre as aventuras de seu sufocante aliado russo. O chamado Concerto da Europa implicava que as nações que eram competitivas em um nível resolveriam assuntos que afetassem a estabilidade geral por consenso $^{73}$.

A incerteza institucional que cercou a Europa em decorrência das invasões napoleônicas, não obstante as supracitadas medidas reacionárias adotadas pelas potências, dificultou a gerência das metrópoles sobre seus domínios, afrouxando um laço fundamentalmente estabelecido e mantido até então pela dominação moral e militar. Assim, permitiu-se, pela primeira vez, a expansão de ideias liberais, de autonomia administrativa e mesmo de independência, reforçadas pelo exemplo da bem-sucedida campanha

\footnotetext{
${ }^{71}$ KISSINGER, Henry. Diplomacy. $1^{\text {a }}$ ed. New York: Simon \& Schuster, 1994. P. 82.

72 KISSINGER, Henry. Diplomacy. P. 83.

${ }^{73}$ KISSINGER, Henry. Diplomacy. P. 83.
} 
empreendida pelos Estados Unidos no século anterior. Movidas por essas circunstâncias, as colônias da América espanhola deram início à sua rebelião generalizada já em 1810, com as declarações de independência de México, Colômbia, Argentina, Venezuela e Equador.

O Brasil, por outro lado, teve a presença colonial fortalecida pela vinda da Corte ao Rio de Janeiro em 1808, permanecendo imune à onda liberal que se espalhava pelo continente. O poder absoluto exercido por D. João VI na colônia — Reino Unido de Portugal, Brasil e Algarves, a partir de 1815 - representou uma verdadeira inversão dos valores constituídos entre metrópole e territórios, consistindo "no abandono das práticas mercantilistas que com maior ou menor coerência Portugal aplicava na sua colónia e na adopção de uma política mais liberalizante" ${ }^{\text {,4 }}$. As ações do monarca foram largamente interpretadas em Portugal como desrespeito da sua importância política e simbólica de capital do império marítimo. A historiadora portuguesa Maria Cândida Proença ilustra o ânimo dos dois lados do oceano:

Se as decisões políticas levadas a efeito no Brasil tinham sido uma retroacção amplificadora de carácter progressivo positivo nos contextos económico e social da colónia, em Portugal, essas medidas tiveram também uma função cumulativa mas de sinal diferente. Aqui [em Portugal] tratou-se de uma amplificação regressiva negativa que a breve trecho conduziu a uma crise porque, não tendo o governo capacidade de apresentar soluções que satisfizessem as exigências emanadas do contexto metropolitano, viu-se confrontado com uma situação de ruptura que acabou por conduzir à revolução que eclodiu no Porto em $1820^{75}$.

D. João VI já dissociou o Brasil da condição clássica de uma colônia com uma de suas primeiras medidas, tomada na cidade de Salvador apenas

\footnotetext{
74 PROENÇA, Maria Cândida. A Independência do Brasil: relações externas portuguesas, 1808/1825. $1^{\text {a }}$ ed. Lisboa: Livros Horizonte, 1987. P. 19.

${ }^{75}$ PROENÇA, Maria Cândida. A Independência do Brasil. P. 42.
} 
quatro dias após a sua chegada. Por meio da Carta Régia de 28 de janeiro de 1808, conhecida como "decreto de abertura dos portos", ele ordenou que fossem "admissiveis nas Alfandegas do Brazil todos e quaesquer generos, fazendas e mercadorias transportados, ou em navios estrangeiros das Potencias, que se conservam em paz e harmonia com a minha Real côroa" ${ }^{, 76}$.

Essa determinação foi, principalmente, uma recompensa pelo auxílio britânico à fuga da família real, que passava a poder negociar mercadorias nos portos do Brasil em caráter quase exclusivo. Além disso, favoreceu o desenvolvimento intelectual e cultural da elite brasileira, até então com ideias bastante retrógradas em virtude de seu isolamento geográfico. "A influência intelectual europeia (...) significava o ponto de vista liberal, composto dum republicanismo otimista, em que as ideias de pacto social e de democracia vestiam a crença racionalista e individualista",77. Raymundo Faoro denota a magnitude dessa mudança:

O comércio estrangeiro, subitamente admitido na colônia, moderniza a acanhada vida colonial, com o padrão de costumes e ideias novas. (...) O nascente antagonismo entre colônia e metrópole quebra-se sob a mole devoradora de fidalgos, concentrando a soberania, a velha e a emergente, sob o trono ${ }^{78}$.

A importância dada à amizade britânica se tornou patente pouco depois, quando Portugal e Reino Unido concluíram, em 1810, dois importantes acordos: o Tratado de Comércio e Navegação e o Tratado de Aliança e Amizade. O primeiro consolidava os laços comerciais entre as nações, determinando taxas de importação/exportação extremamente

\footnotetext{
76 PORTUGAL. Carta Régia de 28 de janeiro de 1808. Disponível em http://www2.camara.leg.br/legin/fed/carreg_sn/anterioresa1824/cartaregia-35757-28-janeiro-1808539177-publicacaooriginal-37144-pe.html. Acesso em 08.06.2018.

${ }^{77}$ SALDANHA, Nelson Nogueira. História das ideias políticas no Brasil. $1^{\mathrm{a}}$ ed. Brasília: Senado Federal, 2001. P. 89.

${ }^{78}$ FAORO, Raymundo. Os donos do poder. 286 e 287.
} 
favoráveis aos navios britânicos. Ademais, criava o "juízo da conservatória inglesa", que garantia imunidade de jurisdição para quaisquer questões envolvendo súditos desse país, que só poderiam ser julgados por um juiz especialmente nomeado por D. João VI, que decidiria com base nas leis britânicas ${ }^{79}$.

O segundo tinha como objetivo principal a formalização da aliança entre as duas nações, contendo um plano internacional para a abolição do tráfico de escravos, já então visto na Europa como uma instituição atrasada que manchava a honra de uma nação civilizada. Ademais, o rei de Portugal garantia a liberdade de culto aos britânicos, afirmando que jamais permitiria a vinda da Inquisição aos seus territórios americanos.

O problema da escravidão foi largamente discutido no Congresso de Viena, tendo sido objeto do Anexo XV do seu Ato Final. Com as independências das colônias espanholas, o Brasil se tornou rapidamente o único importador de escravos africanos do mundo. $\mathrm{O}$ assunto era tão importante que, após a Independência brasileira, chegou a ser um dos pontos fundamentais da negociação para o seu reconhecimento diplomático. Hobsbawm explica que "[a]s razões para isto foram tanto econômicas quanto humanitárias: a escravidão era revoltante e extremamente ineficaz ${ }^{\prime 80}$.

Realmente, as propostas britânicas para a abolição não presumiam necessariamente a concordância de outros países, passando a ser, ao longo

\footnotetext{
79 A conservatória inglesa foi um instrumento jurídico que efetivamente conferiu extraterritorialidade às leis do Reino Unido, importante condição para a continuidade de seu apoio a Portugal e, supostamente, para a manutenção dos interesses comerciais da Grã-Bretanha. Sua importância é tanta que, depois da Independência, uma proposta de tratado mercantil entre o Brasil e o Reino Unido que previa sua revogação foi recusada pelo Secretário de Assuntos Estrangeiros George Canning. Hoje, tal instituto seria impossível, visto que violaria o artigo 17 da Lei de Introdução às Normas do Direito Brasileiro (Decreto-Lei $n^{\circ}$ 4.657/42), pela ofensa à soberania nacional, notadamente ao direito de igualdade formal exposto no art. $5^{\circ}$, caput, da Constituição Federal.

${ }^{80}$ HOBSBAWM, Eric J. A era das revoluções. P. 180.
} 
do tempo, cada vez mais agressivas. $\mathrm{O}$ isolamento brasileiro no assunto acabou por ter sérias consequências econômicas, pois, “caracterizando-se o sistema econômico escravista por uma grande estabilidade estrutural" ${ }^{\text {, }}$, qualquer alteração que nele se operasse era vista como potencialmente cataclísmica. Manuel de Oliveira Lima, diplomata e historiador brasileiro, expõe o entendimento britânico sobre o tema, revelado por Lord Amherst, governador-geral da Índia, em sua visita ao Rio de Janeiro em 1823:

(...) uma nação independente não poderia decentemente preservar uma instituição que era somente tolerável numa colônia, campo de cultivo e comércio, sem a dignidade de uma potência soberana, nem as responsabilidades da defesa de sua integridade territorial. Além disso o Brasil permaneceria isolado, como uma vasta mancha negra, na América Latina livre, único a sustentar um comércio odioso e universalmente reprovado. A justiça britânica ser-lhe-ia facultada, como o sói ser a qualquer país, mas a amizade britânica, essa tinha de ser conquistada mediante aquele sacrifício, que era uma depuração ${ }^{82}$.

Quando se discute o instituto da escravidão, é fundamental ter-se em conta a modificação que, como todas as palavras, seu sentido sofreu ao longo dos séculos. Assim, a análise jurídica dos instrumentos e problemas para sua abolição impõe um anterior cotejo histórico, com a cautela de buscar sempre a significação mais adequada aos debates que então se apresentavam. José Reinaldo de Lima Lopes expõe o problema das continuidades na História, relacionando-o diretamente com o escravismo enquanto instituto jurídico:

Falar em escravos na América portuguesa e no Brasil novecentista pouco tem a ver com a escravidão do mundo antigo (...). Logo, a legitimação da presença de escravos faz-se aqui com elementos jurídicos muito diferentes dos tradicionais. Quando os juristas debatem entre nós, na segunda metade do século XIX, a abolição, o tema proeminente do debate é o direito da propriedade dos

\footnotetext{
${ }^{81}$ FURTADO, Celso. Formação econômica do Brasil. P. 136.

${ }^{82}$ OLIVEIRA LIMA, Manuel de. O reconhecimento do Império: história da diplomacia brasileira. $2^{\mathrm{a}}$ ed. Rio de Janeiro: Topbooks, 2015. P. 76 e 77.
} 
senhores. A constituição imperial, entre os direitos individuais inalienáveis, registrava o direito de propriedade: como abolir a escravidão sem indenizar os senhores pelo seu 'direito adquirido'? ${ }^{83}$.

A primazia do direito de propriedade, afirmada desde o início da colonização do Brasil com a divisão e a cessão das terras régias aos capitães-donatários e a sua prerrogativa legal de distribuir cartas de sesmarias $^{84}$, foi perpetuada por séculos pelos grandes proprietários de terras e escravos. "A política dos nossos homens de Estado foi toda, até hoje, inspirada pelo desejo de fazer a escravidão dissolver-se insensivelmente no país" ${ }^{\prime 85}$. Assim, a construção histórica da escravidão brasileira ainda representava um instituto jurídico firme, sendo determinante a pressão internacional para sua redução e eventual abolição, que viria a ocorrer apenas em 1888, no ocaso do Império.

A despeito desse obstáculo, as relações entre Portugal e Reino Unido chegaram nessa época ao período possivelmente mais harmonioso de sua história. Realmente, a dependência lusitana dos seus aliados insulares passava por aspectos primariamente econômicos, mas não se pode ignorar a influência que esses também exerceram na política e na cultura brasileiras. Seja pela amizade de longa data, pelas inúmeras vantagens oferecidas ou pelo objetivo fundamental de se abolir o tráfico de escravos, é impossível discutir a Independência do Brasil no seu contexto internacional sem atentar

${ }^{83}$ LIMA LOPES, José Reinaldo de. O Direito na História: lições introdutórias. $5^{\text {a }}$ ed. São Paulo: Atlas, 2014. P. 5.

${ }^{84}$ A sesmaria foi criada em Portugal em 1375, sendo derivada do instituto jurídico romano da enfiteuse e destinada a solucionar os problemas de ocupação da terra, desemprego e escassez de cereais. Funcionava por meio da concessão de uma 'carta de sesmaria', que autorizava o donatário a cultivar determinado lote de terra, pagando um dízimo à Ordem de Cristo (na prática, à Coroa Portuguesa), podendo ser revogada caso a terra não fosse cultivada dentro de um prazo preestabelecido. O jurista português Marcello Caetano afirma que a lei tinha o "sentido de desenvolver a agricultura e de empregar a autoridade para forçar os patrões a lavrar a terra e os ciosos a trabalhar nela, combatendo os vícios que já então eram tradicionais em Portugal" (CAETANO, Marcello. História do direito português: 1140-1495. 1ª ed. Lisboa: Verbo, 1981. P. 282).

${ }^{85}$ NABUCO, Joaquim. O abolicionismo. $4^{\text {a }}$ ed. Petrópolis: Vozes, 1977. P. 59 e 60. 
para o papel preponderante que o Reino Unido teve em sua consolidação e reconhecimento.

\subsection{As Conferências de Londres}

Um século antes da Sociedade das Nações, primeira tentativa de organizar o sistema internacional de modo institucional, a aceitação de um ator recém-independente no cenário mundial subordinava-se, em última instância, ao reconhecimento da legitimidade do novo participante pelas grandes potências. (...) Para países transatlânticos, dependentes do comércio marítimo, o decisivo era, no fundo, a postura da potência naval e mercantil por excelência, a GrãBretanha ${ }^{86}$.

Consumada a Declaração de Independência, as dificuldades do Brasil começam a se diversificar. Enquanto as reivindicações dos diversos grupos nacionais poderiam ser até então resumidas na concessão de autonomia, na manutenção dos direitos adquiridos a partir de 1808 e na estruturação de um governo constitucional, as necessidades do país recém-criado eram muito mais complexas.

Para se inserir na comunidade internacional, obtendo as vantagens que dela emanam, o Brasil necessitava do reconhecimento de sua soberania e de seu novo status como ator político autônomo. Para garantir a maior legitimidade possível à Independência e à fundação do novo império, era fundamental obter, o quanto antes, a constatação portuguesa de sua realidade.

Esse entrave era conhecido dos demais Estados europeus, que viam com temor os possíveis efeitos militares e políticos de quaisquer medidas que pudessem ser interpretadas por Portugal como atentatórias à sua soberania. O próprio Reino Unido, ansioso por expandir sua influência

\footnotetext{
${ }^{86}$ RICUPERO, Rubens. A diplomacia na construção do Brasil: 1750-2016. $1^{\text {a }}$ ed. Rio de Janeiro: Versal, 2017. P. 120 e 121.
} 
mercantil ao novo mercado que se abria, julgava prudentemente que qualquer reconhecimento europeu da Independência brasileira deveria ser precedido do seu reconhecimento pela sua antiga metrópole, para que, assim, se consolidasse a situação jurídica do novo país.

A sobrevivência do império, a curto prazo, dependia da prova de seu domínio efetivo sobre todo o seu território. Apenas a partir dessa estabilização, que daria segurança ao regime, é que o governo poderia dispor de representantes, comerciais e diplomáticos, para iniciarem as pertinentes tratativas em diversas nações. Em virtude das insurreições populares — principalmente a Guerra do Madeira na Bahia —, isso só foi possível no início de 1824 , quando D. Pedro I enviou representantes oficiais a Viena, Paris e Londres.

Não obstante esses empecilhos, o governo imperial já havia percebido, em 1823, a importância das boas relações com o Reino Unido. Por isso, enviou a Londres, sob o título informal de "encarregados de negócios", o General Caldeira Brant, Marquês de Barbacena ${ }^{87}$, e Manuel Rodrigues Gameiro Pessoa, Visconde de Itabaiana. Lá, eles se encarregaram de obter as boas graças do governo britânico, principalmente junto a George Canning, Secretário de Assuntos Estrangeiros. Segundo o próprio Caldeira Brant, a missão era vital, pois “o exemplo da Inglaterra reconhecendo a independência seria imediatamente seguido pelas outras potências" $" 88$.

\footnotetext{
${ }^{87}$ Posteriormente, cumprida sua missão, tornou-se "senador do Império, conselheiro de estado, gentil homem da imperial câmara, mordomo-mor da imperatriz a Sra. D. Amélia (hoje [em 1861] duquesa de Bragança), alcaide-mor da vila de Jaguaripe, cavaleiro da ordem de Pedro I, grã-cruz das ordens do Cruzeiro e Rosa, comendador da ordem de Cristo, cavaleiro da Torre da Espada, grã-Cruz da Coroa de Ferro, marechal de exército, membro de várias sociedades científicas e literárias no Brasil e na Europa" (SISSON, Sébastien Auguste. Galeria dos brasileiros ilustres. v2. P. 85).

${ }^{88}$ FAUSTO, Boris; HOLANDA, Sergio Buarque de. O Brasil monárquico: o processo de emancipação. P. 333.
} 
D. João VI acreditava que a resistência brasileira à reunião com Portugal se devia às posturas extremistas mostradas pelas Cortes de Lisboa com vistas à sua recolonização. Assim, tão logo essas foram dissolvidas, o Rei tratou de enviar uma comissão, chefiada pelo Conde de Rio Maior, para negociar diretamente com o Imperador ${ }^{89}$. Suas instruções eram de garantir a D. João VI a restituição da sua soberania sobre o Brasil, além de estipular condições legislativas para que o Brasil pudesse ser administrado de forma autônoma, mas jamais totalmente separada.

O envio da comissão, bem como as ordens que lhe tinham sido dadas, foi comunicado ao Reino Unido, que já se apresentava como possível medianeiro da questão. Canning reprovou a estratégia portuguesa, entendendo que tal dureza apenas serviria para desestabilizar a monarquia recém-criada, deixando as potências europeias sem um "porto seguro" no continente americano. Os temores não se concretizaram: logo que chegou ao Rio de Janeiro, a corveta "Voadora", que transportava os diplomatas, foi tratada como embarcação inimiga, sendo apreendida e integrada na Marinha brasileira $^{90}$. Ficava claro ao Rei de Portugal que qualquer tentativa de reconciliação deveria vir através da mediação externa.

Em 24 de novembro de 1823, já frustradas as negociações diretas, Caldeira Brant e Gameiro Pessoa receberam instruções de Luiz José de Carvalho e Mello, Ministro de Negócios Estrangeiros do Brasil, para que procedessem às tratativas intermediadas. O Ministro destacou nessa carta a irreversibilidade da independência brasileira, encarregando os representantes brasileiros em Londres de fazê-la incontestável por qualquer poder externo. Em meio a outras recomendações, dizia Carvalho e Mello aos diplomatas:

\footnotetext{
${ }^{89}$ VARNHAGEN, Francisco Adolpho de. História da independência do Brasil. P. 245 e 246.

${ }^{90}$ ARMITAGE, John. História do Brasil. P. 140.
} 
Fará ver que nada poderá jamais mudar o sentimento destes povos em sustentar a sua independência e o seu imperador e defensor perpétuo, que por sua parte tem igualmente refletido com madureza sobre os interesses da nação que rege e defende; e jamais retrogradará um só passo da categoria a que está elevado; sendo por isso só calculada a espalhar o azedume e desconfiança toda e qualquer repugnância da parte das outras nações em reconhecer como legítimo um governo fundado na justiça, e na vontade de quatro milhões de habitantes ${ }^{91}$.

A intransigência portuguesa se devia, principalmente, à esperança que mantinha de uma possível vitória do partido português na formação constitucional do novo país, o que poderia facilitar a reunificação desejada. Com a dissolução da Assembleia Constituinte em 1823 e a concentração dos poderes na figura do Imperador, no entanto, esse raciocínio caiu por terra. Isso impeliu D. João VI a aceitar, em março de 1824, a mediação britânica, enviando a Londres o plenipotenciário José Luís de Sousa Botelho Mourão e Vasconcelos, Conde de Vila Real.

A posição destacada do Reino Unido na tentativa de reconciliar metrópole e ex-colônia não passou despercebida pelas nações da Santa Aliança. O governo da Áustria, dirigido pelo príncipe Klemens von Metternich, temia a propagação das ideias liberais britânicas na constituição do Estado brasileiro, o que poderia dificultar a prevalência do princípio monárquico, já tão frágil na América.

José Honório Rodrigues, historiador e "Imortal" da Academia Brasileira de Letras, define Metternich como "o defensor e guarda do status $q u o$, e da restauração do antigo regime contra todos os ímpetos liberais e nacionais" $"$. Nesse intuito, o seu governo se valeu das relações familiares

\footnotetext{
91 "Instruções para servirem de regulamento ao Sr. Manoel Rodrigues Gameiro Pessoa na missão com que parte para a corte de Londres de encarregado de negócios do Império do Brasil", enviadas pelo Ministro Carvalho e Mello em 24.11.1823, in OLIVEIRA LIMA, Manuel de. $O$ reconhecimento do Império. P. 186.

92 RODRIGUES, José Honório. Independência: revolução e contra-revolução: a política internacional. $1^{a}$ ed. Rio de Janeiro: F. Alves, 1975. v5. P. 108.
} 
próximas (Franz I, imperador da Áustria, era sogro de D. Pedro I) para participar da mediação e guiá-la a seu favor, enviando para isso o barão Philipp von Neumann e o príncipe Nikolaus Esterhazy.

Da primeira conferência oficial em Londres, em 12 de julho de 1824, participaram: o Conde de Vila Real por Portugal; Caldeira Brant e Gameiro Pessoa pelo Brasil; Canning pelo Reino Unido; e o barão von Neumann pela Áustria. Os representantes brasileiros prontamente pediram o reconhecimento da Independência, que foi repelida por Vila Real em detrimento de três questões preliminares, fundamentais para a continuidade das tratativas:

$\left(1^{\circ}\right)$ a cessação de hostilidades da parte do Brasil contra Portugal; $\left(2^{\circ}\right)$ o restabelecimento das relações de comércio entre os dois países; e $\left(3^{\circ}\right)$ a restituição das propriedades e embarcações portuguesas apreendidas pelos brasileiros, ou uma indenização equivalente ${ }^{93}$.

A suspensão das hostilidades já era fato consumado para os brasileiros, principalmente depois da derrota do General Madeira na Bahia em julho de 1823; mesmo assim, os diplomatas garantiram que não haveria qualquer movimentação militar contra Portugal enquanto durassem as negociações. Sobre os outros pontos, pediram instruções específicas ao governo do Rio de Janeiro, concordando todos em interromper o encontro para aguardá-las.

Uma semana depois, portanto em 19 de julho, já presente o príncipe Esterhazy, os prepostos mais uma vez se reuniram. Os brasileiros, que já haviam feito pedido de esclarecimentos ao seu governo, perguntaram ao Conde de Vila Real se ele teria poderes para reconhecer a independência e

\footnotetext{
93 "Première Conférence Brézilienne", em 12.07.1824, in OLIVEIRA LIMA, Manuel de. $O$ reconhecimento do Império. P. 191.
} 
os novos títulos do Brasil, ao que este respondeu que nada seria definido até que os três assuntos preliminares estivessem solucionados. Sem propostas de acordo evidentes, Canning sugeriu, "para facilitar o andamento da negociação, redigir seu projeto de reconciliação, para ser em seguida levado em consideração pelas duas partes" $"$.

Infrutíferas até aquele momento as negociações mediadas, a despeito da ardorosa influência de Canning, os representantes de Portugal e do Brasil se reuniram secretamente no dia $1^{\circ}$ de agosto. Nesse encontro, o Conde de Vila Real confessou que suas ordens impediam que ouvisse propostas para o reconhecimento da Independência que não previssem certas compensações. Essas gratificações foram por ele resumidas da seguinte forma:

1) que as duas Coroas se reunissem na cabeça de S. M. Imperial, pela morte de seu Pai; 2) que, no caso da extinção da dinastia de S. Majestade Imperial D. Pedro I, fossem os outros ramos da família de Bragança chamados a suceder na Coroa do Brasil; 3) que o Brasil concedesse favores especiais ao comércio português e tomasse sobre si parte da dívida pública de Portugal ${ }^{95}$.

Os pleitos soaram estranhamente aos ouvidos dos representantes brasileiros, pois, com efeito, nenhum pedido dessa natureza jamais havia sido feito no direito internacional até então. A título de precedentes, os negociantes brasileiros lembraram as situações do próprio Portugal e da Holanda, que, quando de sua separação da Coroa de Espanha, respectivamente em 1640 e 1648, nada pagaram a ela como "reparação".

A terceira conferência ocorreu pouco depois, em 9 de agosto do mesmo ano. Sobre as hostilidades, Caldeira Brant e Gameiro Pessoa deram

\footnotetext{
94 "Seconde Conférence Brézilienne", em 19.07.1824, in OLIVEIRA LIMA, Manuel de. $O$ reconhecimento do Império. P. 192.

${ }_{95}$ RODRIGUES, José Honório. Independência: revolução e contra-revolução: a política internacional. P. 128.
} 
a garantia imperial de que nada seria feito pelo Brasil contra Portugal e as demais colônias portuguesas, solucionando a primeira questão; silenciaram, contudo, sobre os assuntos do comércio e das indenizações. Canning apresentou seu projeto, quase idêntico ao anteriormente oferecido pelos diplomatas brasileiros, que continha 13 artigos no total: 9 na seção principal da carta; 3 em um protocolo adicional; e 1 secreto, dispondo sobre a sucessão da Coroa portuguesa. Caldeira Brant e Gameiro Pessoa, por conselho de Canning, aceitaram o projeto sub spe rati (à espera de ratificação), enquanto Vila Real prometeu submetê-lo à análise do seu governo.

Os diplomatas e mediadores reuniram-se novamente apenas dois dias depois, o que impossibilitou a obtenção da opinião portuguesa sobre o projeto de Canning. Desse modo, o debate foi profundamente improdutivo, resumindo-se à repetição das questões preliminares por Vila Real e às evasivas dos brasileiros. Nesse momento, a firme posição de Portugal quanto a esses assuntos chegou a surtir efeito, cogitando D. Pedro I atendêlas em sua totalidade para facilitar o reconhecimento. Isso só não foi feito por conta de fragilidade imperial perante a opinião pública, que, enriquecida culturalmente pela transferência da Corte dos Braganças em 1808 e pelos consequentes contatos com ideias liberais e estrangeiras, desdenhava de qualquer composição com a antiga metrópole antes de reconhecida e garantida a independência e soberania do Brasil.

Percebendo a relutância de Vila Real e as limitadíssimas ordens que havia recebido enquanto plenipotenciário, Caldeira Brant e Gameiro Pessoa postularam o envio direto do projeto de Canning ao gabinete de D. João VI, para que este autorizasse a sua discussão pelo diplomata em Londres. O plano foi acatado, sendo o documento enviado em nome do próprio ministro britânico, já que a Áustria julgou que tal atuação extrapolaria os limites de sua função como medianeira. 
Enquanto se esperava alguma resposta que pudesse modificar o proceder das negociações, os representantes brasileiros cautelosamente se ocuparam de adquirir armas e navios de guerra, a serem utilizados na ocasião de falharem completamente as tratativas. Também negociaram empréstimos, emitiram apólices e realizaram outras operações financeiras, tudo com vistas a consolidar o Brasil enquanto agente comercial independente.

Em meados de agosto, a Confederação do Equador ${ }^{96}$ já crescia em proporção, embaraçando as relações comerciais e diplomáticas do Brasil em Londres. Segundo Evaldo Cabral de Mello, historiador pernambucano e Imortal da Academia Brasileira de Letras, suas repercussões internacionais demonstravam a fragilidade do governo central, à medida que "prejudicavam não só as negociações sobre o reconhecimento da Independência como também o desembolso das demais parcelas do empréstimo levantado em Londres"97.

O governo português nutria esperanças de que a revolta pudesse enfraquecer o domínio do Imperador, conduzindo à reunificação dos dois países; por isso, as instruções de Vila Real foram de atrasar as negociações, ganhando tempo para que os revolucionários mostrassem um resultado favorável. Seguindo essa diretiva, logo "as gazetas de Lisboa puseram-se a insultar desaforadamente o Brasil ${ }^{198}$.

A franca demora, a hostilidade e a irredutibilidade das atitudes lusitanas irritaram o governo britânico, que se via imobilizado em seus planos de expansão comercial transatlântica até que fosse reconhecida a

\footnotetext{
${ }^{96}$ Iniciada em 02.07.1824, a Confederação foi o primeiro grande movimento de revolta contra os comportamentos autoritários e centralizadores de D. Pedro I, sendo uma resposta direta à Constituição recém-outorgada. Tinha características republicanas e liberais, sendo sustentada em grande parte pela mídia local, com destaque para o jornal Typhis Pernambucano, da editoria de Frei Caneca.

${ }^{97}$ MELLO, Evaldo Cabral de. A outra Independência. P. 222.

${ }^{98}$ OLIVEIRA LIMA, Manuel de. O reconhecimento do Império. P. 94.
} 
independência brasileira pela antiga metrópole. Diante disso, Canning garantiu a Caldeira Brant e Gameiro Pessoa que o Brasil seria o primeiro Estado americano a ser reconhecido pelo Reino Unido, o que seria muito pertinente para ambos os países, visto que os Tratados de 1810 estavam prestes a expirar ${ }^{99}$, tornando-se urgentes novos ajustes para regularizar os termos do vínculo que surgia com o jovem Estado. Na visão do premiê britânico, "o problema seria apenas acomodar, no reconhecimento da independência brasileira, os interesses da Inglaterra com aqueles da velha Europa, o que fez com extrema habilidade"100.

Inobstante a perspectiva nebulosa do reconhecimento britânico, o governo do Rio de Janeiro se tornava impaciente com Portugal, pois o alongamento das negociações trazia obstáculos à atuação econômica e política do Brasil junto aos outros países soberanos. Diante disso, o Imperador proferiu o Despacho de 18 de setembro de 1824, orientando os diplomatas a ceder no assunto da restituição de propriedades e embarcações, bem como a aceitar os pedidos de vantagens comerciais como "nação mais favorecida".

As referidas instruções chegaram a Londres no início de novembro, a tempo para influir na sexta conferência diplomática, marcada para o dia 11 desse mês. Nessa ocasião, o Conde de Vila Real apresentou o contraprojeto português para a reconciliação, exaltando a "moderação que reina em todos

\footnotetext{
99 O direito internacional da época, ancorado no princípio da relatividade, não obrigava a observância brasileira desses pactos, visto que foram firmados com Portugal. Frente à incerteza jurídica e comercial que poderia debilitar o seu governo, D. Pedro I declarou, em 1823, que o Brasil seguiria cumprindo as determinações neles estabelecidas por mera conveniência, até que se pudesse travar um novo acordo diretamente como pátria soberana.

${ }^{100}$ MOTA, Carlos Guilherme. Europeus no Brasil à época da independência: um estudo. In: (Org.). 1822: dimensões. $1^{\mathrm{a}}$ ed. São Paulo: Perspectiva, 1972. P. 72.
} 
os artigos do Projeto que é proposto" e o "espírito de conciliação que Sua Majestade Fidelíssima demonstrou no curso desta negociação"101.

As palavras caridosas do diplomata lusitano, porém, não passavam de engodo. Na realidade, o projeto de tratado apresentado pelo gabinete de Lisboa era profundamente autoritário e negava a realidade dos fatos, buscando impedir a proliferação das instituições liberais nos dois países. Logo em seu início, o documento fulminava os planos brasileiros de ver reconhecida sua independência:

Art. $1^{\circ}$ - As duas partes europeia e americana da monarquia portuguesa terão para o futuro debaixo da soberania do senhor dom João Sexto, e de seus legítimos descendentes, uma Administração respectivamente independente, subsistindo todavia entre elas perpétua união. Cada uma delas poderá ter as suas instituições, e leis apropriadas às suas circunstâncias particulares ${ }^{102}$.

A proposta lusitana, por seu conservadorismo, chocou tanto os representantes brasileiros quanto os mediadores; Canning chegou a afirmar que esta seria "desarrazoada e inadmissível"103. Apesar disso, a recomendação do Ministro britânico aos brasileiros foi de aceitá-la ad referendum ${ }^{104}$, ganhando tempo para evitar o rompimento das tratativas e, por conseguinte, a renovação das hostilidades. O documento "veio a ser rejeitado pelo Conselho de Estado, em sessão de 24 de janeiro de $1825^{\text {"105. }}$.

\footnotetext{
101 "Sixième Conférence Brézilienne", em 11.11.1824, in OLIVEIRA LIMA, Manuel de. $O$ reconhecimento do Império. P. 210.

102 "Esboço de um Ato de Reconciliação entre Portugal e o Brasil", in OLIVEIRA LIMA, Manuel de. O reconhecimento do Império. P. 204.

103 RODRIGUES, José Honório. Independência: revolução e contra-revolução: a política internacional. P. 132.

104 A aceitação ad referendum é uma forma de declaração de vontade tradicional no Direito Internacional Público, na qual se submete o texto do documento à aprovação posterior pela autoridade competente. José Francisco Rezek, ex-Ministro do Supremo Tribunal Federal, explica que é geralmente utilizada nas ocasiões de "não se encontrar o negociador munido de poderes para uma assinatura plena e incondicionada” (REZEK, José Francisco. Direito dos Tratados. $1^{\text {a }}$ ed. Rio de Janeiro: Forense, 1984. P. 201).

${ }^{105}$ VARNHAGEN, Francisco Adolpho de. História da independência do Brasil. P. 302.
} 
Constatada, por todas as partes, a estagnação das tratativas mediadas, a conferência de 11 de novembro de 1824 foi a última de seu tipo. Ainda nesse ano, o Conde de Subserra, Ministro português da Guerra e "partidário estrênuo e fautor principal do domínio francês"106, enviou secretamente o médico José Antônio Soares Leal ao Rio de Janeiro para negociar diretamente os termos do acordo, em uma reprise da fracassada missão do Conde de Rio Maior. Assim como seus antecessores, Soares Leal foi preso e devolvido a Lisboa.

A missão Soares Leal foi tramada sigilosamente e sob os auspícios da Santa Aliança, refletindo o ideal diplomático francês característico de Subserra. A reação de Canning foi dura: impossível a conciliação, declarou oficialmente encerradas as negociações em Londres.

A política estadunidense de celebrar acordos comerciais com alguns Estados americanos recém-criados (Colômbia, México e Buenos Aires) inquietou o governo do Reino Unido, que, a partir de janeiro de 1825, passou também a firmar tratados similares, com vistas a manter a predominância britânica no comércio marítimo. Isso desagradou aos diplomatas brasileiros, aos quais Canning tinha garantido a prioridade no reconhecimento. Em resposta ao à quebra dessa garantia, Caldeira Brant $\mathrm{e}$ Gameiro redigiram uma firme réplica, na qual repudiavam o vilipêndio do Brasil frente às outras nações. Pressionado por Portugal, pelo Brasil e pelas próprias necessidades econômicas e políticas do Reino Unido, Canning resolveu a questão nomeando uma comissão, chefiada por Sir Charles Stuart, experiente diplomata, para ir a Lisboa e ao Rio de Janeiro negociar diretamente.

${ }^{106}$ OLIVEIRA LIMA, Manuel de. O reconhecimento do Império. P. 72. 


\subsection{Sir Charles Stuart e o Tratado de 1825}

A missão de Stuart era complexa: ele precisava conciliar os interesses do Reino Unido com o Brasil, fortalecendo o seu controle mercantil na América, sem indispor o governo britânico com Portugal, seu mais antigo aliado. Por isso, sua primeira parada foi a capital lusitana, onde ele deveria se encontrar com os representantes de D. João VI. Canning emitiu as instruções de Stuart na etapa portuguesa da expedição em uma carta de 14 de março de 1825 , véspera de sua partida:

Resumindo o resultado destas Instruções, Vossa Excelência deve exprimir ao Governo de S. M. Fidelíssima: $1^{\circ}$. Que é opinião e conselho de Sua Majestade que qualquer concessão que S. M. Fidelíssima estiver preparada para fazer ao Brasil deverá ser feita por edito real, e não através de negociação. $2^{\circ}$. Que qualquer concessão a não ser a Independência será totalmente ineficaz. $3^{\circ}$. Que qualquer tentativa de reter o exercício ativo de qualquer dos direitos de soberania sobre o Brasil, declarado independente, também seria ineficaz. (...) Não obstante, se S. M. Fidelíssima preferir uma negociação e um tratado com o Brasil, V. Exa. declarará estar autorizado, se assim o desejar S. M. Fidelíssima, a encarregar-se do dever de Plenipotenciário de S. M. Fidelíssima, desde que os termos com os quais ele concorde estejam dentro da finalidade destas instruções ${ }^{107}$.

No período em que esteve em Lisboa, Stuart participou de nove conferências com o Ministro de Negócios Estrangeiros, Conde de Porto Santo, entre 5 de abril e 23 de maio. Nessas reuniões, eles discutiram a separação dos países, a sucessão das coroas, a indenização pelas propriedades e embarcações e a possibilidade de um tratado de comércio. $\mathrm{O}$ assunto de maior polêmica, porém, era a concessão do título de Imperador do Brasil a D. João VI, mero capricho do rei português, já que não teria qualquer consequência prática.

107 “George Canning a Sir Charles Stuart”, em 14.03.1825, in RODRIGUES, José Honório. Independência: revolução e contra-revolução: a política internacional. P. 315. 
Acertado o pagamento de "indenização" pelo Brasil e a sua assunção de parte da dívida pública portuguesa ${ }^{108}$, Stuart foi nomeado plenipotenciário do governo português, recebendo três versões de uma Carta Régia que reconhecia, em termos distintos, a independência e a soberania do Brasil. "Uma considerando o Rei portando o título de Imperador do Brasil; outra aplicando o título imperial, coletivamente, aos três reinos, em vez de só ao Brasil; e a terceira reconhecendo D. Pedro como Rei do Brasil" "109. Em todas elas, o representante teve o cuidado de garantir o eventual direito de sucessão do Imperador à Coroa portuguesa.

Munido desses documentos, Stuart partiu para o Rio de Janeiro em 24 de maio, lá chegando em 17 de junho. Nos primeiros dias, chegou a se encontrar com D. Pedro I, entregando-lhe uma carta pessoal do rei português que muito o desagradou. Temendo pôr em risco as negociações por seu comportamento "demasiado fogoso" ", o Imperador tratou de nomear três representantes para transacionar com o inglês. Foram eles o Ministro dos Negócios Estrangeiros Luiz José de Carvalho e Mello, o Ministro da Marinha Francisco Vilela Barbosa e o Barão de Santo Amaro, José Egídio Álvares de Almeida ${ }^{111}$.

Nesse momento, posto que já consolidada a autoridade imperial no território brasileiro, a Independência era vista, até mesmo em Portugal, como realidade consumada. Assim, os maiores empecilhos para o avanço das negociações foram os devaneios do rei português quanto ao título

\footnotetext{
108 A assunção de dívida é um instituto que foi criado pelo Direito Romano clássico, mas só aprofundado posteriormente. Importa na transferência de uma dívida, com todos os seus acessórios, a um terceiro, que assume o polo passivo da obrigação, substituindo o devedor originário.

109 RODRIGUES, José Honório. Independência: revolução e contra-revolução: a política internacional. P. 143.

${ }^{110}$ VARNHAGEN, Francisco Adolpho de. História da independência do Brasil. P. 309.

111 FAUSTO, Boris; HOLANDA, Sergio Buarque de. O Brasil monárquico: o processo de emancipação. P. 352.
} 
imperial e à forma de "concessão" da Independência, pretensão que "causou sérios embaraços e quase provocou o fracasso dos entendimentos"112.

D. João VI tentava construir a narrativa de que o Brasil teria se tornado independente por sua vontade e consentimento, derivando a soberania imperial do princípio da legitimidade do poder dos reis ${ }^{113}$. Essa visão contrastava fortemente com a imagem que D. Pedro I, embasado na aclamação popular, havia estabelecido para justificar sua permanência na liderança do Estado. Por isso, o Imperador julgava fundamental que a separação dos países fosse considerada como resultado de uma força política ativa; ele pensava, com razão, que "a liberdade nacional era uma conquista e o Imperador não poderia renegar a soberania popular, porque se arriscava a ser abandonado pelo povo"114.

Ocorreram treze conferências entre os plenipotenciários, durando de 25 de julho a 29 de agosto de $1825^{115}$; era de interesse dos brasileiros que tudo estivesse solucionado até o aniversário da Independência, no dia 7 de setembro. Com o objetivo de agilizar os debates, os negociantes decidiram deixar de lado, ao menos no momento, o assunto da sucessão da dinastia de Bragança; essa determinação resguardou o direito de D. Pedro I ao trono português, mantendo o status quo ante. Passou-se, assim, à discussão da natureza da Independência e do título imperial.

Os representantes do Imperador se mostraram inicialmente intransigentes com o diplomata inglês, não obstante sua seriedade e boa-fé.

\footnotetext{
112 FAUSTO, Boris; HOLANDA, Sergio Buarque de. O Brasil monárquico: o processo de emancipação. P. 352.

${ }^{113}$ Sobre a criação e propagação de narrativas históricas segundo os interesses dominantes, ensina Paul Ricoeur: "Esperamos da história uma certa objetividade, a objetividade que lhe convém: a maneira pela qual a história nasce nô-lo atesta; procede ela sempre da retificação da arrumação oficial e pragmática feita pelas sociedades tradicionais com relação a seu passado" (RICOEUR, Paul. História e verdade. $1^{\mathrm{a}}$ ed. Rio de Janeiro: Forense, 1968. P. 24).

114 RODRIGUES, José Honório. Independência: revolução e contra-revolução: a política internacional. P. 147.

${ }^{115}$ PROENÇA, Maria Cândida. A Independência do Brasil. P. 98.
} 
Segundo os negociadores brasileiros, as três versões da Carta Régia portada por Stuart eram inaceitáveis, porquanto previam a transmissão da soberania de D. João VI a D. Pedro I ou omitiam deste o título de Imperador $^{116}$. O inglês suportou a conduta beligerante dos diplomatas brasileiros com "bastante habilidade e finura"117, adaptando as instruções recebidas de Portugal com intuito conciliador, assumindo os respectivos riscos.

Ávidos por concluir as tratativas antes do sete de setembro e embrandecidos pela destreza diplomática de Stuart, os representantes brasileiros acabariam por ceder na maior parte das suas reivindicações. A mudança substancial no seu posicionamento reflete a falta de uma ordem sólida de prioridades; segundo José Honório Rodrigues, "uma constante de nossa história" ${ }^{118}$. Em outras palavras:

A revolução, quando não desemboca em contra-revolução, acaba em reforma, e a conciliação entre dois princípios extremos, a legitimidade e a aclamação, não estava fora do alcance dos vitoriosos. (...) Depois de tanto embaraço e dificuldade, chegou-se, finalmente, a um acordo, cedendo mais os brasileiros, não só nos princípios, como no dinheiro ${ }^{119}$.

O Tratado de Independência foi celebrado no Rio de Janeiro em 29 de agosto de 1825, sendo ratificado pelo Imperador no dia seguinte. Algumas de suas disposições, por serem consideradas demasiado impopulares, constaram apenas de um protocolo adicional que foi redigido e assinado em segredo. Como dito, o documento representou uma vitória pírrica para o lado brasileiro, que obtinha o tão sonhado reconhecimento a

\footnotetext{
${ }^{116}$ OLIVEIRA LIMA, Manuel de. O reconhecimento do Império. P. 146.

117 VARNHAGEN, Francisco Adolpho de. História da independência do Brasil. P. 311.

118 RODRIGUES, José Honório. Independência: revolução e contra-revolução: a política internacional. P. 149.

119 RODRIGUES, José Honório. Independência: revolução e contra-revolução: a política internacional. P. 149.
} 
custo de pesadas indenizações e da concessão do título imperial a D. João VI.

Os representantes do Imperador conseguiram, ainda que não nos termos mais favoráveis, que o Rei português primeiro reconhecesse a Independência no preâmbulo do Tratado, apenas depois aceitando transferir, "de sua livre vontade, a soberania do dito império [do Brasil] ao mesmo seu filho, e legítimos sucessores, e tomando somente, e reservando para a sua pessoa o mesmo título"120.

Com relação à Carta Régia, que ainda incluía condições inadmissíveis para o Brasil, decidiu-se que seria citada no Tratado, mas jamais publicada; tudo isso com vistas a melhor controlar a opinião popular a respeito. Tudo em vão: a publicação do documento, feita no terceiro aniversário da Independência, ocorreu sem a ratificação de D. João VI, chegando a Portugal por vias não oficiais antes mesmo do retorno de Sir Charles Stuart ${ }^{121}$.

A ocultação da Carta Régia suscitou a desconfiança do povo brasileiro, que já supunha a existência do protocolo secreto. Assim, a opinião pública brasileira se dividiu sobre o tema, sendo a comemoração do dia 7 de setembro apenas uma tentativa de "esconder os enormes sacrifícios ideológicos e econômicos que a negociação custara"122 . O Tratado também foi mal recebido em Portugal, onde não foram publicadas as indenizações a serem pagas pelo Brasil, constantes apenas do protocolo adicional.

Se os termos do Tratado vieram depois a ser desconsiderados ou mesmo ignorados, pouco importava, porquanto, conforme Rui Barbosa,

\footnotetext{
120 "Tratado concluído entre D. João VI, e seu augusto filho, o imperador do Brasil, acerca da independência do respectivo império", em 29.08.1825, in PROENÇA, Maria Cândida. A Independência do Brasil. P. 128 e 129.

${ }_{121}$ VARNHAGEN, Francisco Adolpho de. História da independência do Brasil. P. 313.

122 RODRIGUES, José Honório. Independência: revolução e contra-revolução: a política internacional. P. 152.
} 
"todas as convenções internacionais encerram a cláusula, subentendida sempre, do rebus sic standibus: enquanto as circunstâncias não mudarem; isto é: enquanto outra não for a vontade soberana mais forte" ${ }^{123}$. A despeito das amplas concessões feitas por ambos os lados e da impopularidade do diploma então assinado, o sucesso das negociações foi muito proveitoso ao Brasil, que adquiriu enfim o reconhecimento de sua independência pela antiga metrópole.

123 BARBOSA, Rui. Os conceitos modernos do Direito Internacional. $1^{\mathrm{a}}$ ed. Rio de Janeiro: Fundação Casa de Rui Barbosa, 1983. P 46. 


\section{Formação constitucional do Império do Brasil}

\subsection{Política e Constituição}

As constituições não são produto da vontade dos homens. O tempo é que as faz. Elas vêm à tona gradual e imperceptivelmente. Não são compostas, como se tem pensado, de novos elementos para cuja combinação nenhum cimento seria suficientemente sólido. São constituídas por antigos elementos, mais ou menos modificados ${ }^{124}$.

Nos capítulos anteriores, empreendeu-se um estudo voltado para as circunstâncias políticas e diplomáticas que permitiram e favoreceram a Independência do Brasil. Analisadas, portanto, as bases institucionais e ideológicas da sociedade brasileira da época, faz-se necessário um maior aprofundamento sobre o efetivo resultado desses movimentos, ou seja, o que foi aplicado pelas lideranças surgidas do "independência ou morte" na sistematização jurídica do novo país soberano. Com esse intuito, é fundamental o exame dos principais grupos influentes na elite, das discussões havidas pelos constituintes e do real aproveitamento dessas normas e ideais na Constituição que viria a ser escrita.

Primeiramente, entenda-se que o processo constituinte não é apenas jurídico, mas essencialmente político. A instituição de um ordenamento jurídico requer uma declaração inequívoca de vontade pelos titulares da potestade; em uma sociedade que se diz democrática - ainda que tal perspectiva não se cumpra —, esses são os cidadãos. A multiplicidade de titulares da soberania é que admite a dissonância e a guerra de influências na marcha legislativa constitucional. Carl Schmitt, jurista alemão, entende por isso que o conceito democrático da lei é um conceito político, o que significa que "frente a esta vontade [do povo], não há obstáculos fora dos princípios democráticos" ${ }^{\prime 125}$.

\footnotetext{
${ }^{124}$ CONSTANT, Benjamin. Princípios de política aplicáveis a todos os governos. P. 180.

${ }^{125}$ SCHMITT, Carl. Dottrina della costituzione. $1^{\text {a }}$ ed. Milano: Giuffrè, 1984. P. 340.
} 
Conceber a democracia como forma legítima de representação política, não obstante o remoto exemplo ateniense, era em si um obstáculo ainda no século XVIII. É nos cadafalsos da Revolução Francesa que se encontrou a base institucional que elevou o povo de mero súdito do rei a cidadão, conferindo-lhe direitos e deveres, individuais e coletivos. Consolidou-se a multidão, o Terceiro Estado, independente e absoluto, como "o conjunto dos cidadãos que pertencem à ordem comum" 126 .

O abade Emmanuel Joseph Sieyès, político francês ativo durante a Revolução, via no povo a chance de resolver a crise de legitimidade então reinante no país. Para ele, a nação pode ser definida como "um corpo de associados que vive sob uma lei comum e é representado pela mesma legislatura" ${ }^{127}$. O país dividido em Estados, cada qual com suas normas e privilégios, formava, portanto, uma série de povos distintos dentro do mesmo território, porém jamais uma nação. Qualquer privilégio constitui violação dessa lei comum; qualquer privilegiado se opõe ao Terceiro Estado e, por conseguinte, à nação.

A legitimação do povo enquanto encarnação da vontade geral e essencial da nação transforma o pensamento político vigente; a construção do regime constitucional passa, a partir desse momento, a depender da inferência desse grupo, bem como dos demais já citados, no processo legislativo originário. Os constituintes da nação exercem esses poderes de forma ilimitada e incondicionada, conferindo à sua criação a superioridade que depois se desdobraria no princípio da primazia da Constituição.

Nesta qualidade, seus representantes formam toda a Assembleia Nacional; têm todos os seus poderes. Como são os únicos depositários da vontade geral, não têm necessidade de consultar os seus constituintes sobre uma dissensão que não existe. Sem dúvida, estão sempre dispostos a submeterem-se às

${ }^{126}$ SIEYÈS, Emmanuel Joseph. ¿Qué es el tercer estado?. $1^{\text {a }}$ ed. Madrid: Aguilar, 1973. P. 18.

${ }^{127}$ SIEYÈS, Emmanuel Joseph. ¿Qué es el tercer estado?. P. 13. 
leis que aprouver à nação lhes der. (...) É preciso compreender antes de tudo claramente qual é o objeto ou o fim da assembleia representativa de uma nação; não pode ser diferente do que se proporia a própria nação se pudesse reunir-se e deliberar no mesmo lugar ${ }^{128}$.

A própria eleição dos delegados para exercer o poder constituinte pleno passa por questões de mando ideológico, moldando os grupos que participam, então, da elaboração da lei maior. De fato, a concepção de representatividade que surge e se fortalece a partir das ideias de Sieyès - e de sua efetiva aplicação — serve para horizontalizar os debates, pressupondo um substrato comum sobre o qual se edificará o sistema constitucional. O Frei Caneca, criticando a dissolução imperial da Constituinte na edição de 15 de janeiro de 1824 do Typhis Pernambucano, afirma categoricamente que "é da essência da representação nacional a escolha das matérias que devem formar o objeto do pacto social; porque só a nação é a quem toca e pertence estatuir" ${ }^{129}$.

"Quando se fala de ordem jurídica, supõe-se uma legalidade não arbitrária. Legalidade oriunda do sistema representativo, legalidade criada

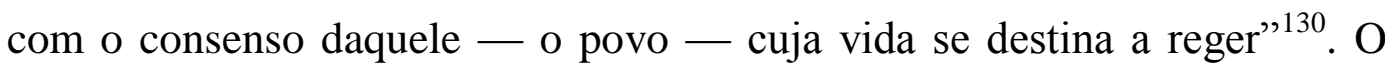
seu processo de criação e consolidação, portanto, é sempre rodeado de conflitos e choques entre alianças, cada qual querendo seus privilégios - o que, como se disse, não pode subsistir. Os ideais e os conceitos que prevalecem frente a essas dificuldades são entendidos como os que, sinteticamente, correspondem à vontade da maior parte das pessoas, ou seja, estão em maior conformidade com a vontade geral. José Afonso da Silva, um dos mais célebres constitucionalistas da história do Brasil, assim define o processo constituinte:

${ }^{128}$ SIEYÈS, Emmanuel Joseph. ¿Qué es el tercer estado?. P 106 e 107.

129 CANECA, Frei Joaquim do Amor Divino. Ensaios políticos. $1^{\text {a }}$ ed. Rio de Janeiro: Documentário, 1976. 82 p.

${ }^{130}$ SEABRA FAGUNDES, Miguel. A legalidade democrática. $1^{\mathrm{a}}$ ed. Recife: OAB/PE, 1970. P. 23. 
A formação de uma constituição democrática é processo incerto e conflitivo. É submetido a jogo de interesses e tensões de toda ordem. Nunca é linear e isento de contradições. Forças contrárias às mudanças reorganizam-se para interrompê-lo. Há riscos de novas e perigosas rupturas ${ }^{131}$.

Os grupos e as alianças que se digladiam durante o momento criativo de uma constituição adaptam, pelo constante embate, os princípios desejados por cada um, mesclando ideais e perspectivas e gerando verdadeiros fundamentos da ordem jurídica nacional. Essas noções se consolidam por sua necessidade; sua forma e aplicação, que embasam as demais leis, são definidas e trazem consigo "a noção de uma necessidade ativa, de uma força eficaz e determinante que atua sobre tudo que nela se baseia, fazendo-a assim e não de outro modo" ${ }^{\prime 132}$.

Ferdinand Lassalle, jurista e político alemão, chama essas forças de "fatores reais do poder"133, coletividades com objetivos comuns e influência ideológico-legislativa independente, podendo abranger além do que é efetivamente escrito. O conjunto de fundamentos por eles defendidos, representados pela soma desses fatores, constitui a verdadeira essência da Constituição real e efetiva de um país.

O diploma legal que então se redige é, nesse raciocínio, apenas uma "folha de papel"134, um instrumento para expressar a soma dos fatores reais do poder de forma escrita, constituindo-os em "fatores jurídicos",135. Esses, então, representam as múltiplas vontades presentes em um país, dialogando, geralmente de forma violenta, para solidificar o sistema do qual são partes. O Patriarca da Independência, José Bonifácio de Andrada e Silva, entendia

\footnotetext{
${ }^{131}$ SILVA, José Afonso da. Poder constituinte e poder popular: estudos sobre a Constituição. $1^{\text {a }}$ ed. São Paulo: Malheiros, 2000. P. 76.

${ }^{132}$ LASSALLE, Ferdinand. A essência da Constituição. $9^{\mathrm{a}}$ ed. Rio de Janeiro: Freitas Bastos, 2014. P. 19.

${ }^{133}$ LASSALLE, Ferdinand. A essência da Constituição. P. 20.

${ }^{134}$ LASSALLE, Ferdinand. A essência da Constituiçãõo. P. 26.

${ }^{135}$ LASSALLE, Ferdinand. A essência da Constituição. P. 26.
} 
que essas forças devem gerar, em síntese, o maior bem para o maior número de pessoas, separando as necessidades internas e complementares dos fatores reais daquelas operadas por agentes externos ou defensores dos privilégios. Dizia ele que "sem independência, não há para as nações nem constituição, nem liberdade, nem pátria" ${ }^{136}$. A vinculação da Constituição jurídica aos fatores reais é patente.

Todos os países possuem ou possuíram sempre e em todos os momentos de sua história uma Constituição real e verdadeira. A diferença nos tempos modernos - e isso não deve ficar esquecido, pois tem muitíssima importância não são as constituições reais e efetivas, mas, sim, as constituições escritas na folha de papel. (...) De onde provém essa aspiração, própria dos tempos modernos, de possuir uma Constituição escrita? Vejamos. Somente pode ter origem, evidentemente, no fato de que nos elementos reais do poder imperantes dentro do país se tenha operado uma transformação ${ }^{137}$.

Os enfrentamentos principiológicos que dão substância à Constituição escrita caracterizam sua mutabilidade, a despeito do objetivo de cristalizar esses valores na sociedade. A mera redação de um documento que concentre e sistematize essas ideias nada importa, podendo ser suplantado a qualquer momento pelos caprichos dos fatores reais do poder.

Assim, o estabelecimento da Constituição escrita seria decorrente dessa transformação dos fatores reais, que veem na rigidez do texto um benefício momentâneo, reservada a possibilidade de se alterar a ordem política sem mudança de texto — por exemplo, com a mutação constitucional. O enfrentamento dos elementos formadores do país é preponderante no processo formativo. A cristalização dos princípios no texto constitucional não deve buscar a perfeição ou o ideal inatingível, mas “observar qual a constituição histórica da sociedade correspondente e (...)

\footnotetext{
${ }^{136}$ ANDRADA E SILVA, José Bonifácio de. Projetos para o Brasil. P. 123.

${ }^{137}$ LASSALLE, Ferdinand. A essência da Constituição. P. 33.
} 
adoptar, como critério, uma sã philosophia (...) que the ajude a desvendar o que a constituição referida tem de imutável e o que tem de modificável”"138.

Konrad Hesse, juiz da Suprema Corte alemã, discorda de Lassalle, interpretando a Constituição escrita como parte autônoma da, porém coordenada com, a Constituição real. Para ele, a folha de papel, longe de ser apenas instituto passivo que se adapta às regras políticas derivadas dos fatores reais, também se mostra como força ativa, criando obrigações e deveres que, por sua vez, podem delinear e regulamentar as relações sociais.

A norma constitucional somente logra atuar se procura construir o futuro com base na natureza singular do presente. Tal como exposto por Humboldt alhures, a norma constitucional mostra-se eficaz, adquire poder e prestígio se for determinada pelo princípio da necessidade. Em outras palavras, a força vital e a eficácia da Constituição assentam-se na sua vinculação às forças espontâneas e às tendências dominantes do seu tempo, o que possibilita o seu desenvolvimento e a sua ordenação objetiva ${ }^{139}$.

Essa "vontade de Constituição" 140 , que se alia à vontade de poder dos titulares da potestade, deve ser alicerçada na preponderância das vontades humanas, que, consonantes ou dissonantes, conformam e reformam a ordem política, conferindo-lhe eficácia. A instituição de cada direito deve levar em conta um correspondente dever, evitando construir uma estrutura unilateral excludente; caso contrário, "a realidade haveria de pôr termo à sua normatividade; os princípios que ela buscava concretizar estariam irremediavelmente derrogados"141.

\footnotetext{
${ }^{138}$ VARELA, Alfredo. Direito constitucional brazileiro: reforma das instituições nacionaes. $1^{\text {a }}$ ed. Rio de Janeiro: Typographia, 1899. P. 37 e 38.

${ }^{139}$ HESSE, Konrad. A força normativa da Constituição. $1^{\text {a }}$ ed. Porto Alegre: Sergio Antonio Fabris Editor, 1991. P. 18.

${ }^{140}$ HESSE, Konrad. A força normativa da Constituição. P. 19 e 20.

${ }^{141}$ HESSE, Konrad. A força normativa da Constituição. P. 21.
} 
Raymundo Faoro debruçou-se sobre o assunto da democracia e da instituição do poder constituinte no Brasil em estudo feito ainda durante a ditadura militar. Segundo ele, a entrada brasileira no processo constitucionalista se deve ao movimento reacionário desencadeado pela Revolução Liberal do Porto em 1820, o que acabou por promover a constitucionalização do regime monárquico português. Consequentemente, afrouxou-se o domínio ideológico exercido diretamente sobre a então colônia, o que conduziu, aliado a outros fatores, à declaração de Independência do Brasil dois anos depois.

O país recém-emancipado atestava, nesse momento, sua metamorfose em nação, estabelecendo os fundamentos e ideais sobre os quais seria erigida sua Constituição. A celeridade em dar início ao processo constituinte - a Assembleia foi convocada em 3 de junho de 1822, mais de três meses antes da Declaração de Independência - demonstra a importância desse expediente, que formaria a base normativa e social do novo governo.

A constituição em sentido social e a constituição em sentido jurídico constituem as duas faces da constituição política. Uma constituição não é, desse modo, a mera síntese das condições reais do poder, nem um conjunto esparso de regras jurídicas. Da interação desses dois fatores, dirigidos pela vocação dos destinatários do poder de controlá-lo, se afirma a essência da constituição, inadmissível, portanto, como maquilagem de pessoas ou dos grupos que se assenhoreiam da força ${ }^{142}$.

A convocação, supostamente democrática, dos delegados constituintes, serviu para propagar a ilusão participativa do povo, buscando neutralizar as suas reivindicações mais radicais. Foi possível, por isso, mascarar a falta de legitimidade que os representantes possuíam,

\footnotetext{
${ }^{142}$ FAORO, Raymundo. Assembleia Constituinte: a legitimidade recuperada. $1^{\text {a }}$ ed. São Paulo:
} Brasiliense, 1981. P. 15 e 16. 
sustentando-se em apelos demagógicos aos apetites populares. A dificuldade intrínseca da formação do governo brasileiro já era clara, já que “sem a plenitude de participação do povo, o governo não será nunca um governo constitucional, mas governo de fato dissimulado em aparências constitucionais ou sem essas aparências" $" 143$.

Feitas as considerações acima e compreendida a natureza do poder constituinte, torna-se possível passar ao exame da primeira assembleia constituinte brasileira, que, apesar das boas intenções, não logrou sucesso em eliminar os arbítrios e os privilégios, sendo sumariamente dissolvida pelo Imperador.

\subsection{Os debates e a dissolução da Constituinte de $\mathbf{1 8 2 3}$}

De que serve uma Constituição em papel? A Constituição deve estar arraigada em nossas leis, estabelecimentos e costumes. Não são comissões militares e medidas ditatoriais que deviam restabelecer a ordem, e sossegar as províncias, mas sim a imediata convocação das câmaras, e um novo ministério sábio, enérgico, e de popularidade ${ }^{144}$.

No início de 1822, D. Pedro I estava já ciente da ineficácia das representações brasileiras nas Cortes de Lisboa. Prevendo a irreconciliabilidade dos diversos interesses presentes no Brasil com os suscitados pela Revolução do Porto, promulgou, em 16 de fevereiro desse ano, um decreto preparatório à separação, que pudesse consolidar o seu poder como Príncipe Regente e servisse de base à sua eventual aclamação popular como monarca soberano.

Nesse documento, criava-se o Conselho de Procuradores Gerais das Províncias, órgão cuja missão seria "examinar os grandes projetos de reformas administrativas (...) e propor as medidas e planos que parecessem

\footnotetext{
${ }^{143}$ FAORO, Raymundo. Assembleia Constituinte. P. 15.

${ }^{144}$ ANDRADA E SILVA, José Bonifácio de. Projetos para o Brasil. P. 122.
} 
mais urgentes e vantajosos ao bem do Reino Unido e do Brasil" ${ }^{\text {"145 }}$. O desejo do futuro Imperador, como exposto no Decreto de 16 de fevereiro, era de que esse trabalhasse

(...) para utilidade geral do Reino-Unido e particular do bom Povo do Brazil, ir de antemão [às Cortes] dispondo e arreigando o systema constitucional, que elle merece, e Eu Jurei dar-lhe, formando desde já um centro de meios e de fins, com que melhor se sustente e defenda a integridade e liberdade deste fertilíssimo e grandioso Paiz, e se promova a sua futura felicidade ${ }^{146}$.

O processo formativo da Assembleia, ainda que posto em curso antes do fatídico 7 de setembro de 1822, como se disse, demorou a se mostrar efetivo. Isso porque o Decreto de 3 de junho desse ano, longe de estabelecer procedimentos específicos para a eleição dos delegados, apenas informava que a Assembleia deveria ser "composta de Deputados das Províncias do Brazil novamente eleitos na forma das instrucções, que em Conselho se acordarem, e que serão publicadas com a maior brevidade"147. A vaga redação do Decreto gerou insegurança e instabilidade, havendo dúvida sobre a própria legitimidade dos eleitos.

Nos primeiros dias após o "Grito do Ipiranga", ainda não se sabia exatamente qual seria a finalidade de tal Assembleia, pois havia forte discordância entre três grupos: um favorável à participação brasileira nas Cortes de Lisboa, restabelecendo o seu status de colônia; outro, mais radical, pressionava pela independência total, com viés democrático e republicano; e, finalmente, um terceiro, formado pelas elites burguesas urbanas, que pregava uma separação branda, mantendo o sistema de governo e legitimando a constituição pela autoridade imperial já

\footnotetext{
${ }^{145}$ LIMA LOPES, José Reinaldo de. O Direito na História. P. 266.

146 BRASIL. Coleção das Leis do Império (1821-1830). Disponível em http://www2.camara.leg.br/atividade-legislativa/legislacao/publicacoes/doimperio/colecao2.html. Acesso em 21.07.2018.

147 BRASIL. Decreto de 3 de junho de 1822. Disponível em http://www.ibrade.org/wpcontent/uploads/2018/03/Decreto-de-3-de-junho-de-1822.pdf Acesso em 06.08.2018.
} 
estabelecida, formalizando os ajustes feitos no período revolucionário pelos fatores reais do poder.

Esse último grupo, mais próximo às lideranças econômicas do país e influente junto às elites europeias, acabou prevalecendo, já que os outros dois, por suas posições radicais, possuíam uma rejeição maior, hostilizando as suas ideologias adversárias. Victor Nunes Leal associa a grande influência desse grupo conservador à amizade e à troca de favores que mantinham com os coronéis do interior, o que lhes permitia mobilizar uma força popular considerável. A instabilidade do sistema político baseado nessa relação é patente: "como os compromissos não são assumidos à base de princípios políticos, mas em torno de coisas concretas, prevalecem para uma ou para poucas eleições próximas" ${ }^{148}$.

Nas palavras de Flávia Lages de Castro, a "monarquia, uma continuidade da dinastia portuguesa no Brasil seria a garantia de manutenção do status quo baseado no sistema que persistia desde a Colônia: latifúndio, monocultor, exportador, escravocrata" $" 149$. Não obstante a indefinição sobre quem viria a tomar a liderança, era certo que todos os grupos tinham uma ideia semelhante sobre o poder que detinham:

Os constituintes, consciente ou inconscientemente, rezavam todos por iguais letras: entre o rei e a nação não havia duas peças pertencentes ao mesmo corpo, que cumpria ajustar, soldar, fundir. O soberano e o país eram realidades diversas e separadas, cujo encontro se daria pela adesão ou pelo contrato, desconfiadas as partes da conduta de uma e outra, tendente o imperador ao despotismo e os representantes da nação à anarquia ${ }^{150}$.

\footnotetext{
${ }^{148}$ LEAL, Victor Nunes. Coronelismo, enxada e voto: o município e o regime representativo no Brasil. $7^{\mathrm{a}}$ ed. São Paulo: Companhia das Letras, 2012. P. 61.

${ }^{149}$ CASTRO, Flávia Lages de. História do direito. P. 345.

${ }^{150}$ FAORO, Raymundo. Os donos do poder. P. 331.
} 
Para além das inclinações políticas, as instruções gerais para a eleição dos delegados foram bastante claras em tornar inelegíveis determinados grupos de oposição ao governo imperial. Nessa lógica, permitiu-se o voto de todo cidadão emancipado com mais de vinte anos de idade, "excluídos os religiosos seculares, os estrangeiros não naturalizados, os criminosos (...), os criados da Casa Real que não fossem de galão branco e os administradores de fazendas e fábricas" ${ }^{151}$. A supressão dos escravos, como bem lembra Lages de Castro, foi implícita, já que esses não eram sequer considerados brasileiros.

O propósito das instruções, na verdade, foi o de limitar o número de pessoas elegíveis, facilitando a prática de manobras políticas para a definição dos constituintes. Assim, o grupo eleito para a Assembleia representava não os ideais do povo, considerado "resignado e apático" mas da elite rural latifundiária e da urbana mercantil. Caio Prado Jr. afirma, por isso, que foi feita a "Independência praticamente à revelia do povo; e se isto lhe poupou sacrifícios, também afastou por completo sua participação na nova ordem política" ${ }^{\prime 53}$.

A falta de participação popular na Constituinte de 1823 - não obstante sua posterior dissolução - permitiu a instauração de um caráter classista no projeto, favorecendo as elites rurais e urbanas com "uma complicada hierarquia de direitos políticos, que (...) vai sucessivamente restringindo o círculo dos cidadãos deles investidos" ${ }^{\text {154 }}$. A dificuldade de fazer valer o direito político da elegibilidade dos cidadãos nos termos das instruções gerais foi premeditada e surtiu efeitos. O Barão Francisco Inácio Marcondes Homem de Mello explica que a Constituinte era composta de

\footnotetext{
${ }^{151}$ CASTRO, Flávia Lages de. História do direito. P. 345.

${ }^{152}$ RODRIGUES, José Honório. Independência: revolução e contra-revolução: a liderança nacional. $1^{\mathrm{a}}$ ed. Rio de Janeiro: F. Alves, 1975. v4. P. 124.

${ }^{153}$ PRADO JR, Caio. Evolução política do Brasil: colônia e império. $16^{a}$ ed. São Paulo: Brasiliense, 1988. P. 52.

${ }^{154}$ PRADO JR, Caio. Evolução política do Brasil. P. 56.
} 
"26 bachareis em direito e cânones, 22 desembargadores, 19 clérigos entre os quaes um bispo, e 7 militares entre os quaes 3 marechaes de campo e 2 brigadeiros" $" 155$.

Os setores sociais que se viram representados na Assembleia correspondiam às lideranças financeiras e intelectuais do país, moldadas pelo liberalismo econômico aliado ao conservadorismo político; como, aliás, eram as Cortes de Lisboa. Nas palavras de José Afonso da Silva, a Assembleia foi "composta da aristocracia intelectual brasileira, graduada em Coimbra, e da Nobreza rural assentada sobre a base dos grandes latifúndios" $" 156$.

As perspectivas democráticas, utilizadas tão-somente para fortalecer a ilusão de representatividade e angariar apoio popular, não passaram de engodo, servindo para manter com maior facilidade o elitismo e o autoritarismo de pequenos grupos. Segundo Victor Nunes Leal, "o latifúndio monocultor e escravocrata representava, a essa época, o verdadeiro centro de poder da Colônia: poder econômico, social e político" $" 157$.

Com efeito, o que se operou foi "um movimento permanente e paciente pela conquista progressiva de espaço político" ${ }^{158}$, ainda que essa fosse limitada, em geral, aos detentores de títulos e proprietários de terras. Antônio Carlos Wolkmer explicita claramente os moldes ideológicos da nova sociedade prestes a se formar:

\footnotetext{
${ }^{155}$ HOMEM DE MELLO, Francisco Inácio Marcondes. A Constituinte perante a História. $1^{\mathrm{a}}$ ed. Rio de Janeiro: Actualidade, 1863. P. 4 e 5.

${ }^{156}$ SILVA, José Afonso da. O constitucionalismo brasileiro: evolução institucional. $1^{\text {a }}$ ed. São Paulo: Malheiros, 2011. P. 46.

${ }^{157}$ LEAL, Victor Nunes. Coronelismo, enxada e voto. P. 81.

${ }^{158}$ BONAVIDES, Paulo; ANDRADE, Antonio Paes de. História constitucional do Brasil. $3^{\mathrm{a}}$ ed. São Paulo: Paz e Terra, 1991. P. 89.
} 
Com a Independência do país, o liberalismo acabou constituindo-se na proposta de progresso e modernização superadora do colonialismo, ainda que, contraditoriamente, admitisse a propriedade escrava e convivesse com a estrutura patrimonialista de poder. (...) Trata-se da complexa e ambígua conciliação entre patrimonialismo e liberalismo, resultando numa estratégia liberal-conservadora que, de um lado permitiria o "favor", o clientelismo e a cooptação; de outro, introduziria uma cultura jurídico-institucional marcadamente formalista, retórica e ornamental ${ }^{159}$.

Eleitos os deputados, o governo central orientou às províncias que fornecessem meios logísticos e financeiros para que esses pudessem se locomover ao Rio de Janeiro. Sem prejuízo, D. Pedro I, acreditando que qualquer demora nos trabalhos da Assembleia seria prejudicial ao país, ordenou, por meio do Decreto de 14 de abril de 1823, o início das suas reuniões preparatórias para três dias depois. Dispôs o futuro Imperador aos deputados que, "começando pela nomeação do Presidente, formarão a Junta preparatória para verificação de poderes, e organizarão o regulamento interno da Assembléa"160.

Logo no dia 17 desse mês, como previsto, reuniram-se os constituintes. Elegeram o bispo capelão-mor D. José Caetano da Silva Coutinho como presidente; nomearam uma comissão para decidir sobre a legalidade dos poderes conferidos aos presentes, cujo relator foi Antonio Carlos Ribeiro de Andrada, irmão de José Bonifácio; e deram início à redação do regimento interno, proferindo um juramento de defender a integridade e a independência do Império.

Em 3 de maio de 1823, finalmente tinham início os trabalhos da Assembleia, em grande festa e sob comoção popular. Pedro Eunápio Deiró, jornalista e político baiano durante o Império, relata o ânimo dos cariocas nesse dia.

${ }^{159}$ WOLKMER, Antônio Carlos. História do direito no Brasil. $3^{\mathrm{a}}$ ed. Rio de Janeiro: Forense, 2002. P. 79.

${ }^{160}$ BRASIL. Coleção das Leis do Império (1821-1830). Acesso em 27.07.2018. 
Havia por toda parte um vivo contentamento; a população julgava assistir a uma esplêndida festa do patriotismo. No homem das classes populares até no das mais elevadas da sociedade, dominava um só sentimento; todos confiavam nos representantes da nação e esperavam que eles realizassem as esperanças, fundando o governo de um povo livre e fazendo uma Constituição que a todos concedesse e garantisse os direitos da liberdade civil e política. O espetáculo, deveras, era novo para um povo recentemente saído do regime colonial, educado na escola corruptora do absolutismo, que impõe o servilismo e recusa admitir que as criaturas humanas têm idênticos direitos e deveres e que a pátria é um patrimônio comum ${ }^{161}$.

Presentes os deputados, foi dado início formal aos trabalhos da Constituinte, procedendo D. Pedro I a discursar sobre a magnitude do país, os seus desejos de liberdade e a construção de um texto constitucional que fosse justo e adequado às particularidades do povo e da época, ao que foi aclamado. Tornou-se polêmica a fala do Imperador no excerto em que afirmou: “defenderia a Pátria, a Nação, e a Constituição, se fosse digna do Brasil e de mim"

A vinculação do projeto constitucional à aprovação do Imperador jamais havia sido discutida; por isso, gerou forte rebuliço entre os deputados presentes. D. Pedro I havia evitado, até o momento, tomar medidas demasiadamente autoritárias, pois julgava que o seu poder era diretamente derivado da aclamação popular ocorrida em $1^{\circ}$ de dezembro de 1822. A súbita mudança de conduta causou alarme entre os constituintes, que decidiram, mesmo contra o voto de Antonio Carlos, responder imediatamente ao Imperador, louvando a glória do trono e a felicidade do povo, que - todos esperavam — seriam mantidos pelo documento que se redigiria.

161 DEIRÓ, Pedro Eunápio da Silva. Fragmentos de estudos da história da Assembleia Constituinte do Brasil. $1^{\mathrm{a}}$ ed. Brasília: Senado Federal, 2006. P. 73 e 74.

162 BRASIL. Ata da Primeira Sessão Ordinária da Assembleia, 03.05.1823. Disponível em https://arquivohistorico.camara.leg.br/index.php/ata-da-primeira-sessao-da-assembleia. Acesso em 11.08.2018. P. 18. 
Esta primeira "fala do trono" - como vieram a ser conhecidas as representações do Imperador à Assembleia e depois ao Congresso derivou inteiramente dos pensamentos de José Bonifácio, Patriarca da Independência, homem muito afeito aos arbítrios e defensor feroz da monarquia constitucional. Eunápio Deiró entende que "na aluvião das frases ouças que José Bonifácio pôs na imperial boca, transparecem, a todo instante, as arrogâncias do regime da realeza absoluta" ${ }^{~} 163$.

Apenas dois dias depois, em 5 de maio, Antonio Carlos, conhecido por ser "orador eloquente, patriota cheio de coragem" ${ }^{164}$, proferiu sua resposta, formal e ponderada, à fala do Imperador. Louvou, nesse discurso, a generosidade e a perspicácia com que o monarca havia prudentemente agido ao convocar a Assembleia soberana, afirmando também a total prevalência do princípio da liberdade e da defesa do constitucionalismo em suas condutas. Esse último ponto foi alvo de muitas críticas, notadamente por Luis Inácio de Andrade Lima, deputado de Pernambuco, que via com temor a ressalva imperial de que a Constituição precisasse ser digna dele ${ }^{165}$. Antonio Carlos, José Bonifácio e seu irmão Martim Francisco Ribeiro de Andrada partiram em defesa de Sua Majestade Imperial, declarando que "ninguém estava obrigado a defender o que não se julgasse digno de si" e, ainda, "que D. Pedro andava bem em não hipotecar apoio a uma cousa que não conhecia ainda" $"$.

Resolvida, tanto quanto possível, a questão da dignidade imperial, a Assembleia passou a eleger deputados para uma comissão encarregada de

\footnotetext{
163 DEIRÓ, Pedro Eunápio da Silva. Fragmentos de estudos da história da Assembleia Constituinte do Brasil. P. 77.

164 RODRIGUES, José Honório. Independência: revolução e contra-revolução: a liderança nacional. P. 39.

${ }^{165}$ A frase não é de D. Pedro I, tendo sido apropriada "do preâmbulo da Carta de 4 de junho de 1814, por meio da qual Luis XVIII [de França] pretende reatar a tradição monárquica" (CASTRO, Flávia Lages de. História do direito. P. 349).

${ }^{166}$ ROURE, Agenor de. Formação constitucional do Brasil. $1^{\text {a }}$ ed. Brasília: Senado Federal, 2016. P. 105.

${ }^{167}$ ROURE, Agenor de. Formação constitucional do Brasil. P. 105.
} 
redigir o projeto de Constituição; desse grupo de sete, fizeram parte Antonio Carlos e José Bonifácio. O seu primeiro trabalho foi o de deliberar acerca do status jurídico de Pedro José da Costa Barros, deputado eleito pelo Ceará, que se encontrava preso, segundo o deputado Pereira de Alencar deixou transparecer, em virtude do "sistema de devassa que José Bonifácio, ministro do Império, por portaria, praticava à maneira despótica do marquês de Pombal"168.

Logo surgiram opiniões conflitantes. Pereira de Alencar, um dos conterrâneos do preso, propôs então o envio de uma carta ao governo determinando a imediata soltura do constituinte ou, ao menos, o seu célere julgamento, para que pudesse participar tão logo possível da Assembleia. Antonio Carlos, prudente e conciliador, se opôs de pronto, alegando que tal ação seria inconstitucional, pois apropriaria competências exclusivas do governo e do judiciário ${ }^{169}$. Nada obstante a heterodoxia da medida, a carta foi enviada e Costa Barros foi libertado na pendência do julgamento; apesar disso, negou-se comparecer à Assembleia até o reconhecimento de sua inocência, o que veio a ocorrer apenas meses depois.

A controvérsia da "inconstitucionalidade sem constituição", posto que sustentada com base nos princípios e costumes do direito da época, indicava a predileção dos constituintes por doutrinas liberais inglesas, sendo sucedida por alguns outros assuntos transitórios. Destacam-se, entre esses, alguns como a adaptação e a sistematização das leis portuguesas que vigiam

168 DEIRÓ, Pedro Eunápio da Silva. Fragmentos de estudos da história da Assembleia Constituinte do Brasil. P. 97.

169 A visão externada por Antonio Carlos nesse episódio reflete, ainda que indiretamente, a influência da doutrina do direito natural na sociedade brasileira da época. A mera falta de um ordenamento jurídico constituído não reverteria o ser humano ao seu estado primitivo, mas o manteria ainda amarrado às normas estipuladas e fiscalizadas pela Natureza. Nas palavras de Hans Kelsen: “A natureza (...) funciona como autoridade normativa, isto é, como autoridade legiferante. Quem observa os seus preceitos, actua justamente. Estes preceitos, isto é, as normas da conduta justa, são imanentes à natureza" (KELSEN, Hans. A Justiça e o Direito Natural. $2^{\mathrm{a}}$ ed. Coimbra: Arménio Amado, 1979. P. 94). 
no país até a construção da nova ordem jurídica ${ }^{170}$; a suposta necessidade de uma proclamação ao país sobre os princípios da Assembleia; e um projeto sobre a liberdade de imprensa.

Mesmo antes de se embrenharem nos temas centrais da futura Constituição, os representantes já externalizavam o desejo de ruptura completa com o colonialismo, trazendo a si o poder de definir as liberdades e deveres gerais. Nas palavras de Hélio Bicudo, essas atitudes demonstravam que as instituições do Direito lusitano, "enfeixadas principalmente no famoso livro $\mathrm{V}$ das Ordenações Filipinas, não mais correspondiam às ideias dominantes e às necessidades dos novos tempos" $" 171$.

Nesse primeiro mês, a Constituinte sofria ainda com a ausência de vários de seus membros, o que impediu, por vezes, a abertura das sessões ordinárias. Como bem aponta Varnhagen, "com estas e outras propostas menos importantes e as nomeações das comissões, haviam sido quase exclusivamente consumidas as sessões havidas até 22 de maio" ${ }^{172}$. A inércia da Assembleia se devia também à enorme inimizade entre alguns grupos ali presentes, notadamente entre as elites rurais latifundiárias e os novos comerciantes urbanos. O historiador e jurista Pedro Calmon evidencia que o "antagonismo colonial, entre o senhor de engenho e o negociante, (...) a separação entre a gleba e o comércio, aumentada pela imprevidência do primeiro e pela ganância do segundo, explodiam em ira patriótica"173.

\footnotetext{
${ }^{170} \mathrm{O}$ regime jurídico do Brasil à época da Independência era sustentado principalmente nas Ordenações Filipinas, conjunto de normas criadas por Filipe I de Espanha durante a União Ibérica (1580-1640). Entraram em vigor em 1603, subsistindo frente ao processo constituinte e vigorando em matéria civil até 1916, quando passou a vigorar o Código Bevilaqua.

${ }^{171}$ BICUDO, Hélio Pereira. O Direito e a Justiça no Brasil: uma análise crítica de cem anos. $1^{\text {a }}$ ed. São Paulo: Símbolo, 1978. P. 14.

${ }^{172}$ VARNHAGEN, Francisco Adolpho de. História da independência do Brasil. P. 228.

${ }^{173}$ CALMON, Pedro. História da civilização brasileira. $1^{\mathrm{a}}$ ed. Brasília: Senado Federal, 2002. P. 189.
} 
Em 22 de maio, foram apresentados dois grandes temas que causaram espanto e geraram dúvidas sobre a competência da Assembleia: a concessão de anistia geral para os combatentes da Independência; e a autorização, ao governo imperial, de selecionar e expelir do país, em três meses, "todos os que ele considerasse como suspeitos de não de todo adictos à causa da Independência" ${ }^{174}$.

A proposta de anistia, de autoria do deputado gaúcho Martins Basto, tomou precedência, sendo rechaçada ferozmente por José Bonifácio e Antonio Carlos, principalmente pela insegurança quanto à competência da Constituinte para isso. Sustentavam os irmãos Andrada que, conquanto a anistia fosse assunto de competência notavelmente legislativa, esse deveria ser restrito a um poder estabelecido, não sendo prudente discuti-la no momento. Além disso, eles julgavam que tal moção poderia "originar dissensões entre a Assembleia e o imperador"175, já que a incumbência de perdoar crimes políticos era do rei desde a publicação do Decreto de 22 de outubro de $1810^{176}$, no mínimo.

A posição dos Andradas foi ouvida sob protesto, sendo a oposição encabeçada por José Custódio Dias, deputado suplente de Minas Gerais. Ele entendia que a aclamação de D. Pedro como Imperador, ocorrida em dezembro do ano anterior, não lhe conferia direitos e atribuições em aberto na pendência do texto constitucional. Expostos os argumentos, a Assembleia decidiu não enfrentar a questão da competência, optando por realizar apenas um juízo de conveniência sobre a anistia. A votação foi de 35 a 17 pela rejeição da proposta ${ }^{177}$.

\footnotetext{
${ }^{174}$ VARNHAGEN, Francisco Adolpho de. História da independência do Brasil. P. 228.

${ }^{175}$ ROURE, Agenor de. Formação constitucional do Brasil. P. 109.

176 BRASIL. Coleção das Leis do Império (1821-1830). Acesso em 27.07.2018. Acesso em 15.08.2018.

${ }^{177}$ ROURE, Agenor de. Formação constitucional do Brasil. P. 110.
} 
Não obstante a tentativa, por parte dos deputados, de impedir maiores atritos com o governo imperial, a relação entre os dois rapidamente se deteriorou. Isso se deu especialmente por conta de artigos, assinados por um anônimo “G. P. T.” e publicados pelo periódico "Diário do Governo", contrários ao constitucionalismo e favoráveis ao poder monárquico absoluto.

O misterioso autor, que se declarava português, incitava o Imperador contra a Assembleia, essa contra aquele, e o povo contra todos. Por isso, logo foi alvo de diversas queixas de deputados e de processo judicial movido pela Constituinte ${ }^{178}$, o que não o impediu de prosseguir com seus escritos; segundo o jornalista Agenor de Roure, ele "parecia ter as costas quentes"179. Ademais, o nome "Diário do Governo" parecia sugerir alguma ligação dos seus editoriais com a linha política seguida pelo Imperador, dando a entender que D. Pedro autorizava os escritos ou, no mínimo, que não teria coragem de agir contra eles; de todo modo, uma imagem desfavorável.

Em 2 de junho de 1823, os deputados decidiram enviar uma carta ao Imperador, congratulando-o pelo aniversário do decreto que convocou a Assembleia. Em resposta, D. Pedro reafirmou seu compromisso com os princípios da monarquia constitucional, rechaçando, assim, a narrativa absolutista do "G. P. T.".

As declarações do monarca, contudo, não convenceram a todos; o deputado Custódio Dias seguiu pregando que a legitimidade política da Assembleia era absoluta e que a do Imperador dependeria de sua aceitação

${ }^{178}$ BRASIL. Indicação n. 1 para se processar o autor da carta inserta no Diário do Governo $n$. 124. Disponível em https://arquivohistorico.camara.leg.br/index.php/indicacao-n-1-para-seprocessar-o-autor-da-carta-inserta-no-diario-do-governo-n-124. Acesso em 15.08.2018.

${ }^{179}$ ROURE, Agenor de. Formação constitucional do Brasil. P. 114. 
do projeto redigido pelos representantes da nação, da forma em que fosse escrito, sendo ou não "digna dele".

O deputado avistava o problema da legitimação enquanto fonte de obrigações, e, por isso, procurou delimitar de maneira inequívoca qual seria o fundamento desse poder. Em sua concepção, a aclamação imperial era apenas sinal de continuidade conservadora tradicionalista, não podendo se confundir com a formação de uma nova ordem jurídica e política. Nas palavras de Norberto Bobbio, Senador vitalício da Itália, há sempre dicotomia entre o passado e o futuro enquanto fontes de legitimação política, cabendo a cada grupo sustentar o que lhe seja mais favorável, de acordo com suas predileções políticas. Nesse sentido, ele contrapõe o ordenamento conservador ao revolucionário:

Enquanto a referência à história passada constitui um típico critério para a legitimação do poder constituído, a referência à história futura constitui um dos critérios para a legitimação do poder que se está constituindo. $\mathrm{O}$ novo ordenamento que o revolucionário tende a impor deslocando o antigo pode ser justificado na medida em que é representado como uma nova etapa do curso histórico, uma etapa necessária, inevitável e mais avançada axiologicamente do que a precedente ${ }^{180}$.

Hábil negociador, Antonio Carlos chamou seu colega à ordem, argumentando que o mesmo povo que convocara a Assembleia havia também aclamado o Imperador, decorrendo os dois institutos da mesma autoridade, outorgada pelo titular do poder constituinte. A posterior decisão do monarca de convocar a Assembleia estaria, desse modo, prevista nos poderes a ele conferidos pela aclamação popular. Manoel Gonçalves Ferreira Filho explica que, no preâmbulo do que viria a ser a Constituição

\footnotetext{
${ }^{180}$ BOBBIO, Norberto. Estado, governo, sociedade: para uma teoria geral da política. $1^{\text {a }}$ ed. Rio
} de Janeiro: Paz e Terra, 1987. P. 90. 
outorgada, “D. Pedro I (...) invoca a soberania do direito divino, 'a graça de Deus', e a soberania popular, 'a unânime aclamação dos povos"’181.

O Frei Caneca, jornalista e religioso pernambucano politicamente ativo durante o Primeiro Reinado, escreveu sobre a situação política da época nas suas "Cartas de Pítia a Damão" 182 . Na epístola intitulada "Sobre os projetos despóticos do Ministério do Rio de Janeiro", posterior a fevereiro de 1823 , ele faz uma análise da natureza do poder constituinte no Brasil, concluindo que:

O poder soberano é indivisível, ele está todo essencialmente na nação, e por comissão ou delegação nas cortes soberanas, as quais já abrangem aquela mesma parte, que tocava a S.M.I. e Constitucional não por ser príncipe regente do Brasil, nem da casa de Bragança, nem finalmente por ser o sucessor do trono português, sim unicamente por que, aceitando os nossos convites, desprezou e abjurou ser português, e se naturalizou brasileiro; o que se não fizesse, e regressasse para Portugal, nós nos teríamos constituídos como quiséssemos, e posto à nossa frente quem nos parecesse, como têm feito em semelhantes circunstâncias todos os povos do mundo, desde os mais remotos séculos ${ }^{183}$.

$\mathrm{O}$ atrito entre a Assembleia e Governo aumentava constantemente, havendo muitas críticas sobre a influência de Martim Francisco e José Bonifácio, que cumpriam, a um só tempo, os cargos de deputados constituintes e de Ministros do Império. O deputado gaúcho Martins Basto, quando da discussão da anistia, chamou atenção para o fato de que a ideologia patriota e liberal pregada pelo governo era embuste, servindo de máscara para atrocidades e arbitrariedades cometidas em nome do novo país, com a prisão e a perseguição política de centenas de pessoas.

Eunápio Deiró assevera que a preponderância de José Bonifácio no primeiro ano após a Independência se deve muito à ignorância

${ }^{181}$ FERREIRA FILHO, Manoel Gonçalves. O poder constituinte. $4^{\mathrm{a}}$ ed. São Paulo: Saraiva, 2005. P. 64.

${ }^{182}$ Conto da mitologia grega relatado por Aristóxeno, a amizade entre os dois é símbolo das virtudes de lealdade e confiança.

${ }^{183}$ CANECA, Frei Joaquim do Amor Divino. Ensaios políticos. 46 p. 
administrativa de muitos deputados. Ao contrário, com a análise cuidadosa dos seus atos "o ministério do venerando patriarca negrejaria aos olhos da história, como coisa por demais absurda, ou inepta"184. Segundo o autor, as condutas dos Andradas ecoavam mesmo as do Marquês de Pombal, tratado apenas como o "truculento estadista de D. José I""185.

Por isso, desejando acalmar os ânimos dos constituintes e do próprio povo, D. Pedro I demitiu os Andradas em 16 de julho de 1823, um dia depois de proclamar poeticamente que sua constitucionalidade triunfaria sempre, "qual sol dissipando o mais espesso nevoeiro"186. Esse ato apaziguador representou uma violenta mudança no comportamento do Imperador, que, se antes "depositava cega e profunda confiança no ministro que havia escolhido"187, agora via como necessária a composição com a Assembleia para manter o projeto de Independência.

Com a dissolução do ministério chefiado por José Bonifácio, ele e seu irmão Martim Francisco se juntaram a Antonio Carlos como deputados da Assembleia em tempo integral. No intuito de garantir a relevância política das suas opiniões, os três passaram a orientar as publicações do "Tamoio" $" 188$, um periódico politicamente independente que, mais do que apoiar definitivamente um ou outro grupo, refletia unicamente as visões dos seus criadores.

Por vezes elogiando, por vezes criticando o Imperador, o jornal foi a solução encontrada pelo Patriarca e seus irmãos para continuar participando

\footnotetext{
184 DEIRÓ, Pedro Eunápio da Silva. Fragmentos de estudos da história da Assembleia Constituinte do Brasil. P. 99 e 100.

185 DEIRÓ, Pedro Eunápio da Silva. Fragmentos de estudos da história da Assembleia Constituinte do Brasil. P. 100.

${ }^{186}$ BRASIL. Coleção das Leis do Império (1821-1830). Acesso em 17.08.2018.

187 DEIRÓ, Pedro Eunápio da Silva. Fragmentos de estudos da história da Assembleia Constituinte do Brasil. P. 160.

188 Nome de uma tradicional tribo de índios, das mais antigas instaladas no litoral brasileiro. Encontravam-se principalmente entre os estados de Rio de Janeiro e São Paulo, sendo "notáveis pela inimizade que professavam contra os portugueses" (ARMITAGE, John. História do Brasil. P. 139).
} 
do cenário político nacional; sua ideologia vacilante era, porém, forte indício de que ele, a despeito das pretensões monárquicas e liberalizantes que sempre havia defendido, "andava magoado pela mudança que se operara no espírito de D. Pedro I" ${ }^{\prime 189}$. Varnhagen, remetendo à análise de Armitage, caracteriza os editores do periódico como "democratas, facciosos, demagogos e revolucionários" ${ }^{\prime 190}$.

Tão logo demitidos os Andradas, dedicou-se o Imperador a reverter algumas das suas atitudes mais autoritárias, buscando, com isso, reparar as relações com o povo e com a Assembleia. Foi com essa finalidade que publicou diversas portarias, a chefes de polícia e a magistrados, ordenando a soltura de inúmeros supostos "inimigos do Brasil" que se encontravam presos sem culpa formada ${ }^{191}$. Primeiramente dirigidas à província de São Paulo, as ordens logo foram expandidas para todo o território nacional, inaugurando uma nova fase no governo, na pendência da Constituição.

Apesar de ter sido breve, a Assembleia de 1823 operou profundas mudanças, tanto na sua composição quanto na sua configuração partidária, do início das sessões, em maio, até a apresentação do primeiro projeto de Constituição, que veio a ocorrer somente em setembro do mesmo ano. Os principais vetores dessas mudanças foram, sem dúvidas, a dissolução do ministério dos Andradas e a pressão de D. Pedro I pela "dignidade" do texto, situações que compeliram a reorganização das forças políticas na Constituinte para melhor se adequarem à vontade popular (e imperial).

\footnotetext{
${ }^{189}$ ROURE, Agenor de. Formação constitucional do Brasil. P. 221.

${ }^{190}$ VARNHAGEN, Francisco Adolpho de. História da independência do Brasil. P. 239.

191 O punitivismo é traço marcante da civilização brasileira desde sua origem, persistindo até a atualidade. Ora por razões políticas, ora por interesses econômicos, a massa popular sempre foi vista com temor, devendo, por isso, ser neutralizada para se atingir a segurança e o progresso nacionais. Demonstrando a permanência do raciocínio punitivista no Brasil, o Conselho Nacional de Justiça publica mensalmente o Relatório Mensal do Cadastro Nacional de Inspeções nos Estabelecimentos Penais (CNIEP), que expõe os seguintes dados: do total de 693.222 presos em todo o país, 245.055 , ou $35 \%$ deles, são presos provisórios - rectius, sem culpa formada (CONSELHO NACIONAL DE JUSTIÇA. Dados das inspeções nos estabelecimentos penais Geopresídios. Disponível em http://www.cnj.jus.br/inspecao_penal/mapa.php. Acesso em 16.10.2018.
} 
Após um mês de agosto improdutivo, mais ocupado com questões políticas supervenientes do que propriamente com a escrita da Constituição, finalmente a comissão encarregada pelo primeiro rascunho, chefiada por Antonio Carlos, ofereceu seu projeto na sessão de $1^{\circ}$ de setembro. Segundo o Barão Homem de Mello, o seu teor era, em linhas gerais, o seguinte:

Todos os grandes princípios das liberdades constitucionaes, todas as novas conquistas do systema representativo, era [sic] ahi proclamados e consagrados. A liberdade pessoal, a igualdade perante a lei, a publicidade do processo, a abolição do confisco e da infâmia das penas, a liberdade religiosa, a liberdade d' imprensa e de industria, a garantia da propriedade, o julgamento pelo jury eram ahi solemnemente reconhecidos ${ }^{192}$.

O projeto, feito sob os olhares internacionais e o temor do absolutismo, seguiu o espírito do constitucionalismo que vinha se desenvolvendo nos Estados Unidos e na Europa: focou-se nas liberdades individuais e na representatividade do sistema eleitoral. A despeito disso, a moderação aplicada às garantias e aos direitos previstos no texto refletia, em termos, o frágil equilíbrio estabelecido nas relações entre a Assembleia e o Imperador.

O projeto de Constituição foi impresso e distribuído aos deputados, a D. Pedro I e às províncias em 9 de setembro, sendo marcada sua discussão para o dia 15 do mesmo mês, pouco antes da chegada da corveta "Voador" ao Rio de Janeiro (como relatado anteriormente). O primeiro debate efetivamente realizado sobre o projeto, refletindo a prolixidade dos procedimentos e o extremo formalismo dos constituintes, foi proposto pelo deputado mineiro Antônio Gonçalves Gomide: postulava alterar o título do documento, de "projeto de Constituição" para "projeto da Constituição".

${ }^{192}$ HOMEM DE MELLO, Francisco Inácio Marcondes. A Constituinte perante a História. P. 9. 
Nem encerrado esse incidente, outros deputados suscitaram correções gramaticais, sendo essas seguidas de debates sobre as expressões religiosas no preâmbulo do texto. Discutiu-se de tudo: o mistério da Trindade; a natureza do Espírito Santo; teologia e medicina. Sobre o projeto em si, contudo, nada foi dito. Nas palavras de Agenor de Roure, "o primeiro dia de discussão da Constituição perdeu-se com duas questões gramaticais e uma religiosa, inteiramente descabidas ${ } 193$.

As posteriores discussões abarcaram todos os grandes temas pertinentes à formação e consolidação de um novo Estado, o que permitiu o refinamento do texto, visto até então como mera repetição feita "no molde da [Constituição] de Portugal" ${ }^{\prime 194}$. A base legal então redigida foi considerada positiva, tanto que foi mantida em sua maior parte pela Constituição Imperial outorgada em 1824, não obstante a futura dissolução da Assembleia - com a notável inclusão do Poder Moderador.

Apesar de todos os desacordos entre os constituintes e o governo imperial, certo é que a Assembleia parecia se encaminhar para um fim proveitoso, quando outra intervenção da imprensa abalou as relações políticas na capital. Em outubro de 1823, o jornal "Sentinela da Liberdade à Beira-Mar da Praia Grande", cujo redator era Cypriano Barata, publicou uma série de cartas assinadas pelo pseudônimo "Brasileiro Resoluto", nas quais se condenava a naturalização de soldados portugueses e a sua incorporação ao Exército Brasileiro ${ }^{195}$.

Em reação às ofensas publicadas, dois oficiais luso-brasileiros foram à paisana a uma botica no Largo da Carioca, onde, acreditavam, encontrariam o autor dos insultos. Lá chegando, na noite do dia 5 de

\footnotetext{
${ }^{193}$ ROURE, Agenor de. Formação constitucional do Brasil. P. 139.

${ }^{194}$ VARNHAGEN, Francisco Adolpho de. História da independência do Brasil. P. 242.

195 FAUSTO, Boris; HOLANDA, Sergio Buarque de. O Brasil monárquico: o processo de emancipação. P. 249.
} 
novembro, encontraram David Pamplona, que foi imediatamente espancado sob a acusação de ser o "Brasileiro Resoluto", quando nem brasileiro era (havia nascido nos Açores) ${ }^{196}$.

Logo no dia seguinte, Pamplona foi queixar-se dos militares à Assembleia, que de pronto adotou o caso, nomeando uma comissão para produzir um parecer sobre o ocorrido. Antonio Carlos e Martim Francisco clamaram vingança contra os ofensores, constituindo-se em "advogados acérrimos do queixoso, que converteram em brasileiro nato, e pretenderam ver na agressão ofensa à honra e dignidade da nação" ${ }^{\text {,197 }}$.

Após a redação do parecer em tempo recorde, foi marcada a sua discussão para o dia 10 de novembro. Houve ampla comoção popular, a favor e contra os agressores, aglomerando-se uma multidão no entorno da Assembleia. Após fortes pressões políticas, autorizou-se a entrada dos manifestantes no recinto, onde, causando grande alarde, forçaram a suspensão dos debates ${ }^{198}$.

D. Pedro I assistia aos acontecimentos com olhar astuto; via nessa situação a oportunidade perfeita para se livrar da influência dos Andradas no projeto que estava sendo redigido. Suas opções eram duas: propôs ao Conselho de Estado a deportação dos Andradas ou a dissolução da própria Constituinte, ao que foi surpreendido com a demissão da maior parte do ministério. Agindo quase isoladamente, aproveitou o ímpeto violento do Exército, atiçado pelas acusações, ordenando a um regimento de infantaria que se dirigisse ao local da Assembleia em São Cristóvão, no que foi seguido por diversos outros batalhões ${ }^{199}$.

${ }^{196}$ LEAL, Aurelino. História constitucional do Brasil. $1^{\text {a }}$ ed. Brasília: Senado Federal, 2014. P. 68 e 69.

${ }^{197}$ VARNHAGEN, Francisco Adolpho de. História da independência do Brasil. P. 260.

${ }^{198}$ ARMITAGE, John. História do Brasil. P. 141.

${ }^{199}$ ARMITAGE, John. História do Brasil. P. 141. 
O uso ostensivo do aparato militar, feito em ameaça velada à Assembleia, foi um divisor de águas na política de D. Pedro I. Se antes o Imperador representava um bastião do patriotismo, do governo moderado e da causa brasileira, "daí em diante toda a sua fraqueza, teimosia, impetuosidade, vacilação, desconfiança, incontenção, venceram suas qualidades e o despotismo foi a funesta consequência" ${ }^{200}$.

Em resposta às suspeitas movimentações militares no entorno da Assembleia, Antonio Carlos propôs, já no dia 11 de novembro, que a Constituinte se declarasse em sessão permanente, enviando um ofício ao Imperador questionando sobre a presença do Exército. A resposta do governo, que chegou apenas na madrugada do mesmo dia posteriormente denominada "noite da agonia" -, informava que as tropas ali estavam em paz, propondo-se apenas a salvaguardar a integridade dos deputados e representar contra as ofensas que esses estariam proferindo contra o Imperador ${ }^{201}$.

Estava armada a crise. Seguiram-se propostas de transferir a Assembleia para outra província e de ordenar o afastamento das tropas; tudo em vão. No dia 12 de novembro de 1823, D. Pedro I marchou à frente das tropas e decretou a dissolução da Constituinte sob o pretexto, facilmente desmentido, de "garantir-lhes a segurança" ${ }^{202}$. A despeito dos verdadeiros motivos, o decreto foi assim redigido:

Havendo eu convocado, como tinha direito de convocar, a Assembléa Geral Constituinte e Legislativa, por Decreto de 3 de Junho do anno proximo passado, afim de salvar o Brazil dos perigos, que lhe estavam imminentes; e havendo esta Assembléa perjurado ao tão solemne juramento, que prestou à Nação, de defender a integridade do Imperio, sua independencia, e a minha

\footnotetext{
200 RODRIGUES, José Honório. Independência: revolução e contra-revolução: a liderança nacional. P. 11.

${ }^{201}$ LEAL, Aurelino. História constitucional do Brasil. P. 72.

202 FAUSTO, Boris; HOLANDA, Sergio Buarque de. O Brasil monárquico: o processo de emancipação. P. 252.
} 
dynastia: Hei por bem, como Imperador, e Defensor Perpetuo do Brazil, dissolver a mesma Assembléa, e convocar já uma outra na fórma das Instrucçoes, feitas para a convocação desta, que agora acaba; a qual deverá trabalhar sobre o projecto de constituição, que eu lhe hei de em breve apresentar; que será duplicadamente mais liberal, do que o que a extincta Assembléa acabou de fazer. Os meus Ministros, e Secretarios de Estado de todas as differentes repartições o tenham assim entendido, e façam executar a bem da salvação do Imperio ${ }^{203}$.

A pressa do Imperador era tanta que mandou formar uma comissão para elaborar o projeto, dando-lhe quarenta dias para tanto. Mesmo antes do fim do prazo, no dia 11 de dezembro de 1823, os trabalhos se encerraram, sendo o projeto publicado no dia 20 do mesmo mês ${ }^{204}$. Após o assentimento das Câmaras Municipais, a primeira Constituição do Brasil foi jurada em 25 de março de 1824. Segundo Marcello Cerqueira, "assim foi o mau começo do constitucionalismo brasileiro" 205 .

\subsection{Constituição Imperial de $\mathbf{1 8 2 4}$}

Eu sou de voto, [sic] que se não adote e muito menos jure o projeto de que se trata, por ser inteiramente mau, pois não garante a independência do Brasil, ameaça a sua integridade, oprime a liberdade dos povos, ataca a soberania da nação e nos arrasta ao maior dos crimes contra a divindade, qual o perjúrio, e nos é apresentado da maneira mais coativa e tirânica ${ }^{206}$.

O relato das discussões havidas na Assembleia, acima, permite compreender quais eram os principais interesses dos grupos que, após executar o projeto da Independência, se haviam encarregado de sistematizálo. Por demasiada arrogância ou leviandade, entretanto, não contaram os constituintes com a existência de outra força capaz de pôr abaixo todos os esforços, como efetivamente ocorreu: o Imperador.

\footnotetext{
${ }^{203}$ BRASIL. Coleção das Leis do Império (1821-1830). Acesso em 17.08.2018.

${ }^{204}$ FAUSTO, Boris; HOLANDA, Sergio Buarque de. O Brasil monárquico: o processo de emancipação. P. 253.

${ }^{205}$ CERQUEIRA, Marcello. A constituição na história: origem e reforma. $1^{\text {a }}$ ed. Rio de Janeiro: Revan, 1993. P. 268.

${ }^{206}$ CANECA, Frei Joaquim do Amor Divino. Ensaios políticos. P. 75.
} 
D. Pedro I, criado para ser rei absoluto, mas doutrinado por maçons e liberais em prol da separação, era um "caleidoscópio de contradições" 207 . A imprevisibilidade, de caráter e ideias, que o levou à dissolução da Assembleia seria a mesma que ordenaria, pouquíssimo tempo depois, a outorga de um texto muito similar ao projeto desfeito:

Imbuída de ideias e instituições marcadamente liberais, originadas da Revolução Francesa e de doutrinas do constitucionalismo francês (...). Tratava-se de uma Constituição outorgada que institucionalizou uma monarquia parlamentar, impregnada por um individualismo econômico e um acentuado centralismo político. Naturalmente, essa Lei Maior afirmava-se idealmente mediante uma fachada liberal que ocultava a escravidão e excluía a maioria da população do país $^{208}$.

Pedro Calmon classifica a Carta de 1824 como de "pouco sentimento econômico, daltonismo político, mimetismo e preocupação de conceitos 'da moda', literários" ${ }^{209}$. O seu conteúdo geral não refletia, com efeito, só a conjuntura nacional recente, inserindo-se no contexto internacional das monarquias que, restauradas após o Congresso de Viena, restauraram seu domínio com base na liberalização das políticas e na concessão de direitos e cidadania. O fundamento da legitimidade dos reis não poderia mais residir no direito divino; assim, foi preciso que eles deixassem "participar do poder ao menos uma parte da elite econômica" ${ }^{210}$, a primeira concepção do liberalismo político na Europa.

A legitimidade do poder consolidado na figura de D. Pedro I foi objeto de amplas discussões nas Cortes de Lisboa. Entendiam os deputados portugueses que todos os atos do Imperador, desde a criação do Conselho de Procuradores, teriam ultrapassado os poderes que the haviam sido

\footnotetext{
${ }^{207}$ BITAR, Orlando. Missão constitucional de Pedro I. In:__. Obras completas de Orlando Bitar: estudos de Direito Constitucional e Direito do Trabalho. v2. P. 327.

${ }^{208}$ WOLKMER, Antônio Carlos. História do direito no Brasil. P. 84 e 85.

${ }^{209}$ CALMON, Pedro. História da civilização brasileira. P. 203.

${ }^{210}$ LIMA LOPES, José Reinaldo de. O Direito na História. P. 353.
} 
concedidos por D. João VI, pois, em sua perspectiva, "não passava de um delegado d el-rei na América"211. Por isso, a outorga da Constituição seria apenas "ordem de uma autoridade ilegítima e incompetente",212.

Afastada a teoria divina da legitimidade política ${ }^{213}$, embasou-se D. Pedro I na teoria da hereditariedade, que depois se convalidou através do que veio a chamar de "unânime aclamação dos povos". A real extensão do seu direito hereditário, muito mais amplo do que o de simples representante do rei, estava provada por um conselho que D. João VI lhe havia dado quando regressou a Portugal, e que depois seria citado pelo próprio Imperador em uma carta que enviou ao pai em 19 de junho de $1822^{214}$.

Pleno conhecedor das ambições das Cortes e desejando a continuidade do regime dentro do possível, disse o rei a seu filho que "se o Brasil se separar, antes seja para ti, que me hás de respeitar, que para algum desses aventureiros" ${ }^{215}$. Tal base legítima de exercício do poder foi, depois da Independência, trasladada para a nova situação do Brasil, como ensina Miguel Seabra Fagundes:

A legitimidade, para o governo do novo Estado, lhe resulta, então, do exercício imediatamente anterior do poder como Príncipe Regente, que convertido em monarca soberano, [sic] pela Declaração de Independência, permanecia titular do poder sem solução de continuidade. (...) Aliás, a legitimação do poder se integra, nessa altura, pela adoção de uma ordem constitucional elaborada, adrede, para o novo Estado ${ }^{216}$.

\footnotetext{
${ }^{211}$ HOLANDA, Sergio Buarque de. Para uma pré-história do Império do Brasil. In:_. Capítulos de história do Império. $1^{\mathrm{a}}$ ed. São Paulo: Companhia das Letras, 2010. Parte I, Cap. 1, p. 34.

${ }^{212}$ HOLANDA, Sergio Buarque de. Para uma pré-história do Império do Brasil. In:_. Capítulos de história do Império. P. 34.

213 “O direito daquele que detém o poder público, isto é, do soberano, é tão só o direito natural, o qual se define pela potência não de cada um dos cidadãos, tomados à parte, mas da massa conduzida de certo modo por um mesmo pensamento" (SPINOZA, Baruch de. Tratado político. $2^{\mathrm{a}}$ ed. São Paulo: Ícone, 1994. P. 41)

${ }^{214}$ OLIVEIRA LIMA, Manuel de. O movimento da Independência. P. 381.

215 RODRIGUES, José Honório. Independência: revolução e contra-revolução: a evolução política. P. 169.

${ }^{216}$ SEABRA FAGUNDES, Miguel. A legitimidade do poder político na experiência brasileira. $1^{\mathrm{a}}$ ed. Recife: OAB/PE, 1982. P. 16.
} 
"Em nome da Santíssima Trindade", iniciava a Constituição de 1824 com a definição do tipo de Estado e de governo que seriam aplicados no Brasil. No seu primeiro artigo, estipulava que o novo país seria considerado a "associação política de todos os cidadãos brasileiros", "uma nação livre e independente" ${ }^{217}$, declaração preponderante para consolidar o movimento político dos anos antecedentes.

José Antonio Pimenta Bueno - o marquês de São Vicente analisando os processos históricos que produziram nossa separação, conclui que "a primeira condição da nação brasileira é pois de ser livre, soberana, independente" ${ }^{218}$. Para sustentar esse princípio, o art. 145 da Constituição instituía que "todos os brasileiros são obrigados a pegar em armas para sustentar a independência e integridade do Império"219.

O governo do país, definido no artigo $3^{\circ}$ da Carta, seria "monárquico hereditário, constitucional e representativo" ${ }^{220}$, o que sustentava a narrativa imperial da continuidade do poder alicerçada na aclamação popular, coadunando-se também com os princípios do constitucionalismo liberal da época. A partir daí, instituindo o catolicismo como religião de Estado, porém permitindo todas as outras para culto privado (art. $5^{\circ}$ ), passava à definição subjetiva da cidadania.

$\mathrm{O}$ art. $6^{\circ}$ determinava inúmeras formas de aquisição de nacionalidade brasileira - muitas seriam replicadas nas constituições seguintes —, mas foi o seu $\S^{\circ}$ que causou mais polêmica. Dispunha que seriam considerados brasileiros "todos os nascidos em Portugal e suas possessões que, sendo já

\footnotetext{
217 MIRANDA, Jorge. Textos históricos do Direito Constitucional. $1^{\mathrm{a}}$ ed. Lisboa: Imprensa Nacional, 1980. P. 197.

218 PIMENTA BUENO, José Antonio. Direito público brasileiro e análise da Constituição do Império. $1^{\mathrm{a}}$ ed. Rio de Janeiro: Ministério da Justiça, 1958. P. 20.

${ }_{219}$ MIRANDA, Jorge. Textos históricos do Direito Constitucional. P. 219.

${ }^{220}$ MIRANDA, Jorge. Textos históricos do Direito Constitucional. P. 198.
} 
residentes no Brasil na época em que se proclamou a independência nas províncias onde habitavam, aderiram a esta, expressa ou tacitamente"221.

Esse princípio já vinha sendo aplicado mesmo antes da outorga da Constituição, tendo sido objeto de deliberação pela Assembleia de 1823. De fato, a Constituinte já havia concedido, aos militares portugueses que houvessem atuado a favor da independência, a nacionalidade e a incorporação ao Exército Brasileiro. Foi justamente esse tema que deu origem às críticas feitas pelo "Brasileiro Resoluto", que conduziriam ao espancamento de David Pamplona e à dissolução da Assembleia.

Apesar de toda a controvérsia, derivada em parte do sentimento nativista antilusitano ocorrente principalmente em Pernambuco, na Bahia e no Rio de Janeiro, Pimenta Bueno considera que a disposição foi "justa, política e útil; mas era por sua natureza transitória". Segundo ele, a exclusão dos portugueses seria "uma injustiça e um erro" ${ }^{222}$, já que muitos deles teriam posto suas vidas e ideais em risco pelo bem da Independência. A Constituição não se olvidou dos combatentes e manteve seu direito à cidadania mesmo contra a insatisfação de parte do povo.

Com relação ao poder de Estado, a Carta de 1824 seguiu parte da doutrina de Montesquieu ${ }^{223}$, reconhecendo a necessidade de reparti-lo. Esse preceito foi consagrado pelo seu art. $9^{\circ}$, que considerava a separação e a harmonia dos poderes como "o princípio conservador do direito dos cidadãos e o mais seguro meio de fazer efectivas as garantias que a

${ }^{221}$ MIRANDA, Jorge. Textos históricos do Direito Constitucional. P. 198.

${ }^{222}$ PIMENTA BUENO, José Antonio. Direito público brasileiro e análise da Constituição do Império. P. 446.

223 "Há em cada Estado três tipos de poderes: o poder legislativo, o poder executivo das coisas que dependem do direito das gentes e o poder executivo das que dependem do direito civil. (...) Tudo estaria perdido se o mesmo homem ou o mesmo corpo de principais ou de nobres ou do povo exercesse estes três poderes: o de fazer as leis, o de executar as resoluções públicas e o de julgar os crimes ou os litígios dos particulares" (MONTESQUIEU, Charles de Secondat, Baron de. Do espírito das leis. $1^{\mathrm{a}}$ ed. São Paulo: Martin Claret, 2014. P. 230 e 231). 
Constituição oferece"224. A divisão que se propôs e aplicou foi integralmente derivada do pensamento de Benjamin Constant, que, vivendo à época da Revolução Francesa, pensou do seguinte modo:

O poder executivo, o poder legislativo e o poder judiciário são três molas que devem cooperar, cada um em sua esfera, ao movimento geral; mas quando, descompostas, se cruzam, entrechocam e se travam, é necessária uma força que os ponha de novo em seu lugar. (...) É preciso que esteja situada fora e que seja, em alguma medida, neutra, a fim de que sua ação se aplique em quantos pontos se requeira e o faça com um critério preservador, reparador, não hostil ${ }^{225}$.

$\mathrm{O}$ art. 10 da Constituição deixava clara a influência de Constant, separando o poder de Estado em Legislativo, Executivo, Judiciário e Moderador; esse último cumpriria a função preservadora da soberania, harmonizando os demais. De acordo com o marquês de São Vicente, todos os poderes são "expressões naturais e necessárias da Soberania Nacional"226 , servindo para sistematizar o ordenamento jurídico.

O Poder Moderador merece especial atenção, sendo o grande divisor de águas na teoria política da fragmentação de poderes e, nas palavras de Paulo Bonavides, "a consagração literal do absolutismo"227. Definido no art. 98 como "a chave de toda a organização política" 228 e encarnado na figura de D. Pedro I, era interpretado como uma seção do Poder Executivo que geria diretamente as questões de soberania, harmonia e independência.

Seria, nessa ótica, não um exercício de absolutismo, mas "um remédio aos impasses do partidarismo, (...) um remédio para a paralisia decisória ou para o predomínio de interesses particulares" ${ }^{\text {229. Afonso }}$ Arinos de Mello Franco pondera que a fundamentação não passou de

\footnotetext{
${ }^{224}$ MIRANDA, Jorge. Textos históricos do Direito Constitucional. P. 199.

${ }^{225}$ CONSTANT, Benjamin. Principios de politica. $1^{\text {a }}$ ed. Madrid: Aguilar, 1970. P. 19.

${ }^{226}$ PIMENTA BUENO, José Antonio. Direito público brasileiro e análise da Constituição do Império. P. 30.

${ }^{227}$ BONAVIDES, Paulo. Teoria Geral do Estado. 10a ed. São Paulo: Malheiros, 2015. 600 p.

${ }^{228}$ MIRANDA, Jorge. Textos históricos do Direito Constitucional. P. 211.

${ }^{229}$ LIMA LOPES, José Reinaldo de. O Direito na História. P. 272.
} 
embuste; D. Pedro I se valeu dessa doutrina "mais no intuito de alargar o seu poder pessoal do que no de estabelecer um equilíbrio neutro entre os demais poderes" ${ }^{230}$, opostamente à indicação de Constant.

As atribuições do Imperador nessa seara eram definidas no art. $101 \mathrm{e}$ incluíam poderes como: dissolver a Câmara de Deputados "nos casos em que o exigir a salvação do Estado" ${ }^{231}\left(\$ 5^{\circ}\right)$; nomear e demitir os ministros de Estado $\left(\$ 6^{\circ}\right)$; suspender os magistrados $\left(\$ 7^{\circ}\right)$; perdoar penas de réus condenados $\left(\$ 8^{\circ}\right)$; e conceder anistia $\left(\$ 9^{\circ}\right)$. Sobre a possibilidade de dissolver a Câmara, certamente a mais polêmica de todas, diz Pimenta Bueno que a luta constante entre esta e o Ministério justificava a atuação do Imperador. Externo às vicissitudes da política rotineira, o soberano teria o bem nacional em mente, agindo sempre "que se dá um desacordo irreconciliável entre a Câmara dos Deputados e o ministério" ${ }^{232}$.

Os outros incisos eram fundamentados nos abusos e incorreções que permeavam os outros três poderes desde o descobrimento do Brasil. Podese dizer, segundo o desembargador Joaquim Rodrigues de Sousa, que:

Foi ella a primeira [Constituição], [sic] que separou o poder real do executivo, em que as mais constituições os tinham baralhados. (...) O Legislador Brazileiro, comprehendendo-a perfeitamente, realizou a distincção, separando das funcções executivas as puramente soberanas, que constituem a missão essencial e indeclinavel da corôa. Reservando privativamente estas funcções ao Imperador, ficando as executivas para ele exercital-as pelos seus ministros d'estado, colocouo na eminente posição soberana, propria para manter a independencia, equilibrio e harmonia dos poderes politicos ${ }^{233}$.

${ }^{230}$ MELLO FRANCO, Afonso Arinos de. O Constitucionalismo brasileiro na primeira metade do século XIX. In:__. Estudos de direito constitucional. $1^{\mathrm{a}}$ ed. Rio de Janeiro: Forense, 1957. Cap. VI, p. 246.

${ }^{231}$ MIRANDA, Jorge. Textos históricos do Direito Constitucional. P. 212.

${ }^{232}$ PIMENTA BUENO, José Antonio. Direito público brasileiro e análise da Constituição do Império. P. 207.

${ }^{233}$ SOUSA, Joaquim Rodrigues de. Analyse e comentário da Constituição Politica do Imperio do Brazil: ou theoria e pratica do governo constitucional brazileiro. $1^{\text {a }}$ ed. São Luiz do Maranhão: B. de Mattos, 1867. v1. P. X. 
Bem-intencionada à primeira vista, talvez nem tanto sob análise apurada, fato é que a doutrina do Poder Moderador foi recebida com espanto e revolta. Clovis Bevilaqua, escrevendo já durante a República Velha, critica as tentativas de reformar a obra de Montesquieu, asseverando que a "triplice feição do poder politico (...) constitue uma verdade definitivamente adquirida pela sciencia"${ }^{234}$.

O Frei Caneca, discursando na Câmara Municipal do Recife acerca do projeto de Constituição que lhe havia sido exposto, entendia que o quarto poder seria parte de um aparato para engessar a ação política do povo. Ironizando a redação do art. 98, disse que "o poder moderador de nova invenção maquiavélica é a chave mestra da opressão da nação brasileira e o garrote mais forte da liberdade dos povos" ${ }^{\text {"235 }}$. Caneca foi tão acirradamente contrário à Constituição Imperial que propôs se rejeitasse a própria discussão de seu conteúdo. Na mesma manifestação à Câmara do Recife, chamou atenção à fonte do poder que buscava instaurar a Carta e da forma como o projeto havia sido apresentado:

É princípio conhecido pelas luzes do presente século, e até confessado por S.M., que a soberania, isto é, aquele poder sobre o qual não há outro, reside na nação essencialmente; (...) como S.M.I. não é nação, não tem soberania, nem comissão da nação brasileira para arranjar esboços de constituição e apresentálos, não vem este projeto de fonte legítima, e por isso se deve rejeitar por exceção de incompetência ${ }^{236}$.

O Poder Legislativo era regido por uma Assembleia Geral — "com a sanção do imperador"237 — bicameral (arts. 13 e 14). A Câmara dos Deputados, de mandato temporário e eletivo (art. 35), tinha competência privativa para legislar sobre tributos, recrutamento e, curiosamente, "sobre

\footnotetext{
${ }^{234}$ BEVILAQUA, Clovis. Juristas philosophos. $1^{\mathrm{a}}$ ed. Salvador: Magalhães, 1897. 143 p.

${ }^{235}$ CANECA, Frei Joaquim do Amor Divino. Ensaios políticos. P. 70.

${ }^{236}$ CANECA, Frei Joaquim do Amor Divino. Ensaios políticos. P. 72 e 73.

${ }^{237}$ MIRANDA, Jorge. Textos históricos do Direito Constitucional. P. 199.
} 
a escolha da nova dinastia no caso de extinção da imperante"238 (art. 36). O Senado, por outro lado, era vitalício e de nomeação pelo Imperador após eleição provincial (art. 40), competindo-lhe conhecer das infrações cometidas pela família imperial, ministros, conselheiros e senadores, além de convocar a Assembleia em caso de morte do Imperador (art. 47).

A proposição das leis competia a cada uma das câmaras em separado. Criou-se um sistema representativo composto "do Imperador elemento de perpetuidade; do Senado - elemento de ordem e conservação; da Câmara dos Deputados — elemento de progresso e liberdade",239. Iniciando-se o processo legislativo em uma câmara, caberia à outra sua análise e revisão (arts. 57 e 60), passando-se, então, à sanção imperial (arts. 62 a 70). Era também permitido aos ministros de Estado apresentar projetos à Câmara, que seriam debatidos por uma comissão especial antes de ser adotados e enviados ao Senado para revisão (art. 53 a 56).

As eleições para as duas câmaras da Assembleia se realizavam de forma indireta, em duas etapas: o povo elegia os eleitores das províncias e estes, por sua vez, votavam nos representantes da nação (art. 90). O direito ao voto nas assembleias paroquiais estava condicionado à idade mínima de 25 anos e à renda líquida anual de cem mil réis, sendo vedado aos criados e aos religiosos (art. 92). Para votar nos deputados e senadores em si, a limitação passava a duzentos mil réis em renda líquida anual; para se eleger deputado, seriam quatrocentos mil réis (arts. 94 e 95). Em suma, o populismo e o ideal de justiça que tinham sido, ao menos em teoria, fundamentos da revolução e da instituição do novo regime, eram descartados em virtude da representatividade política dos donos de terras e comerciantes, em notório caráter patrimonialista. Conforme Wilson Accioli:

\footnotetext{
${ }^{238}$ MIRANDA, Jorge. Textos históricos do Direito Constitucional. P. 202.

${ }^{239}$ SOUSA, Joaquim Rodrigues de. Analyse e comentário da Constituição Politica do Imperio do Brazil. v1. P. 206.
} 
No Brasil, a despeito do pensamento liberal preponderante em parte, parece ter-lhe escapado a liderança do movimento de libertação total, talvez pela carência do apoio efetivo dos quadros políticos, e mesmo das elites intelectuais comprometidas possivelmente com o poder dominante ${ }^{240}$.

O Poder Executivo era delegado ao Imperador, mas exercido pelos seus ministros de Estado (art. 102); era o poder "encarregado e fiscal da execução das leis" e o "agente da deliberação e impulsão, como guarda da segurança interna e externa da alta administração do Estado"241. Entre suas principais atribuições, competia ao Ministério nomear bispos $\left(\S 2^{\circ}\right)$, magistrados $\left(\$ 3^{\circ}\right)$, comandantes das Forças Armadas $\left(\$ 5^{\circ}\right)$ e diplomatas $\left(\S 6^{\circ}\right)$, bem como firmar tratados $\left(\S 8^{\circ}\right)$ e declarar guerra e paz $\left(\S 9^{\circ}\right)$, tudo com o conhecimento da Assembleia Geral.

O Ministério era formado por secretarias de Estado (art. 131), organizadas de acordo com as disposições de leis ordinárias. Durante a maior parte do Império, essas foram seis: Negócios do Império, Negócios Estrangeiros, Fazenda, Justiça, Guerra, e Marinha, sendo criada apenas em 1862 a secretaria de Agricultura, Comércio e Obras Públicas. A direção do Ministério era exercida inicialmente por todos, individualmente; a partir de 1847, surgiu a figura do Presidente do Conselho de Ministros, que coordenava as funções do Ministério como um primeiro-ministro ${ }^{242}$.

A Constituição reconhecia a existência de responsabilidade política dos ministros pelos seus atos, instituto que viria a se expandir, ao longo da história brasileira, a muitos outros cargos públicos. Pelo art. 133, eram considerados crimes de responsabilidade a traição, o suborno, o abuso de poder, o descumprimento da lei, atos contra a liberdade, segurança ou

\footnotetext{
${ }^{240}$ ACCIOLI, Wilson. Reforma e contra-reforma na Constituição de 1824. Revista de Informação Legislativa. Brasília, v. 11, nº 43, p. 161, jul./set. 1974.

${ }^{241}$ PIMENTA BUENO, José Antonio. Direito público brasileiro e análise da Constituição do Império. P. 223.

${ }^{242}$ SILVA, José Afonso da. O constitucionalismo brasileiro. P. 395.
} 
propriedade dos cidadãos e, por fim, qualquer tipo de "dissipação dos bens públicos"243, que depois se veio a chamar de improbidade administrativa ${ }^{244}$.

O Poder Judiciário — ou Judicial — consagrava o princípio da independência, sendo composto de magistrados, nomeados pelo Ministério, e de jurados; estes para se pronunciar sobre os fatos e aqueles para aplicar o direito (arts. 151 e 152). Aos juízes, era assegurada a perpetuidade no cargo, sendo possível, porém, a sua remoção para outras localidades e a sua suspensão pelo Imperador em casos de queixa (arts. 153 a 155).

A exemplo dos ministros, os juízes tinham responsabilidade jurídica pelos seus atos, podendo ser processados por abuso de poder, prevaricação e suborno (arts.156 e 157); nesse último caso, havia previsão de ação popular para julgar o delito. Os princípios da conciliação e da publicidade dos processos judiciais, importantes marcos do nosso ordenamento até hoje, eram enfatizados como essenciais à produção da justiça. Pimenta Bueno conclui que a publicidade era "sempre útil", constituindo "um corretivo contra os abusos e um meio de obter-se responsabilidade moral do juiz"245; quanto à conciliação, diz que pretendia "prevenir demandas inconsideradas, e com elas inimizades e prejuízos que causam males aos indivíduos, assim como à paz das família, e à riqueza pública" ${ }^{246}$.

Economicamente liberal em seu âmago, a Carta de 1824 também previu a instauração de juízos arbitrais, em causas cíveis e penais

\footnotetext{
${ }^{243}$ MIRANDA, Jorge. Textos históricos do Direito Constitucional. P. 217 e 218.

${ }^{244}$ Esse instituto, extremamente amplo na Constituição de 1988 (art. 37, §4 ${ }^{\circ}$, regulamentado pela Lei $\mathrm{n}^{\circ}$ 8.429/1992), pode levar à suspensão dos direitos políticos, à perda da função pública, à indisponibilidade de bens e ao ressarcimento ao erário. Os seus fundamentos autorizam inclusive o enquadramento de pessoas que, a rigor, não são servidores, mas atuam como agentes públicos, tudo com vista a responsabilizar e compensar severamente os danos gerados ao patrimônio do Estado.

${ }^{245}$ PIMENTA BUENO, José Antonio. Direito público brasileiro e análise da Constituição do Império. P. 328.

${ }^{246}$ PIMENTA BUENO, José Antonio. Direito público brasileiro e análise da Constituição do Império. P. 332.
} 
"civilmente intentadas" árbitro, que teria competência exclusiva para tratar da questão. Permitia-se que as partes renunciassem ao direito de recurso, o que favorecia a pronta execução da sentença (art. 160). Nas palavras de um magistrado da época:

A escolha de arbitros, feita livremente pelas partes [sic] é o meio mais humanitario e social de resolverem-se as questões, ficando com o seu direito aquella que o tem, sem prejuizo da mutua paz e benevolencia. (...) Pode tambem a lei determinar que decidam-se certas questões pelo meio arbitral em proveito da vantagem publica, [sic] e particular que elle offerece; não permitindo à vontade $\mathrm{e}$ capricho particular a decisão contenciosa ${ }^{248}$.

A administração das províncias era delegada diretamente pelo Imperador, que nomeava Presidentes para exercer o governo local. Podia removê-los livremente, sempre que entendesse que convinha "ao bom serviço do Estado" (art. 165) ${ }^{249}$. Com essa prerrogativa, o Imperador efetivamente engessava as gestões provinciais, vinculando a nomeação dos Presidentes à sua concordância com as políticas do governo central. Segundo Victor Nunes Leal, essa prática “contribuía para simplificar o mecanismo da política do interior durante o Império" ${ }^{, 250}$.

O Título VIII, que encerra a Constituição de 1824, fala dos direitos civis e políticos dos cidadãos brasileiros. A colocação desse tema ao fim do texto, em completa oposição à atual Constituição de 1988, revela a diminuta importância que a sociedade política da época dava aos direitos individuais. $\mathrm{O}$ art. 179 enunciava todas as prerrogativas dos cidadãos, consagrando no seu caput os princípios da liberdade, da segurança individual e da propriedade. Esse último, preponderante no assunto da escravidão, era justificado pela noção de que "a propriedade real, assim como a intelectual

\footnotetext{
${ }^{247}$ MIRANDA, Jorge. Textos históricos do Direito Constitucional. P. 221.

${ }^{248}$ SOUSA, Joaquim Rodrigues de. Analyse e comentário da Constituição Politica do Imperio do Brazil: ou theoria e pratica do governo constitucional brazileiro. $1^{\mathrm{a}}$ ed. São Luiz do Maranhão: B. de Mattos, 1870. v2. P. 396.

${ }^{249}$ MIRANDA, Jorge. Textos históricos do Direito Constitucional. P. 221.

${ }^{250}$ LEAL, Victor Nunes. Coronelismo, enxada e voto. P. 232.
} 
ou moral, tem pois a sua origem na natureza, e é sagrada, porque, como já dissemos, é o fruto dos esforços, fadigas e sacrifícios do homem"251.

O primeiro parágrafo do dispositivo, a exemplo do que foi posto no art. $5^{\circ}$, II, da Constituição de 1988, declarava que ninguém seria obrigado a fazer ou deixar de fazer algo senão em virtude de lei — princípio da legalidade. Além disso, previam-se os princípios da irretroatividade das leis $\left(\S 3^{\circ}\right)$, da liberdade de expressão e de imprensa ${ }^{252}\left(\S 4^{\circ}\right)$ e da liberdade religiosa $\left(\$ 5^{\circ}\right)$, todos reprisados na Carta de 1988.

As similaridades formais entre as duas Constituições não cessam aí: nos seus 35 parágrafos, o art. 179 exalta a inviolabilidade do domicílio $\left(\S 7^{\circ}\right)$ e da correspondência $\left(\$ 27^{\circ}\right)$, a presunção de inocência $\left(\$ 8^{\circ}\right)$, a isonomia $\left(\S 13^{\circ}\right)$, a abolição da tortura e das penas cruéis $\left(\S 19^{\circ}\right)$ e o direito de propriedade, excetuando os casos de desapropriação por razão de interesse público $(\S 22)$.

Em vistosa inovação, dada a incipiência dos diplomas constitucionais no início do século XIX, também se garantia a propriedade intelectual sobre as invenções e descobertas $\left(\$ 26^{\circ}\right)$, instituindo-se também o direito à educação primária e a sua gratuidade $\left(\$ 32^{\circ}\right)$, bem como o estabelecimento e a manutenção de colégios e universidades pelo governo $\left(\S 33^{\circ}\right)$.

\footnotetext{
251 PIMENTA BUENO, José Antonio. Direito público brasileiro e análise da Constituição do Império. P. 419.

${ }^{252}$ Tal norma foi seguida com ressalvas, já que a previsão de responsabilidade dos jornalistas pelos "abusos" cometidos no exercício do direito foi regulamentada pela rigorosa Lei de Imprensa de 1830. Esse diploma estabelecia uma miríade de delitos relativos à liberdade de expressão, incluindo escritos contra o Império, suas leis, sua religião oficial e à Assembleia, dentre muitos outros (art. $2^{\circ}$ ). O julgamento desses crimes poderia ser direcionado ao impressor, ao editor, ao autor e ao vendedor do texto impugnado, solidariamente (art. $7^{\circ}$ - BRASIL. Lei de 20 de setembro de 1830. Disponível em http://www2.camara.leg.br/legin/fed/lei_sn/1824-1899/lei37987-20-setembro-1830-565654-publicacaooriginal-89402-pl.html. Acesso em 11.10.2018).
} 
"Nenhum systema repressivo pode livrar-se de abusos"253. No intuito de prevenir tais excessos do próprio governo, a lei também facultava aos cidadãos o direito de petição, para que pudessem “expor qualquer infracção da Constituição, requerendo perante a competente autoridade a efectiva responsabilidade aos infractores" ${ }^{254}\left(\S 30^{\circ}\right)$. Ademais, criava responsabilidade para os agentes públicos $\left(\$ 29^{\circ}\right)$ - no que seria a base do art. 37 da Constituição de 1988 - e restringia o poder do Estado de suspender todos os direitos expostos no artigo $\left(\$ 34^{\circ}\right)$, vinculando essa ação à existência de rebelião ou invasão de inimigos $\left(\$ 35^{\circ}\right)$.

A Constituição de 1824 foi, a um só tempo, moderna e ultrapassada. Consagrava o constitucionalismo francês, criado a partir das ideias de Montesquieu, mas o condicionava ao jugo do Poder Moderador. Pregava a isonomia, mas estipulava distinções econômicas nos direitos políticos. A exemplo do que ocorreu em Portugal com as Cortes de Lisboa, o movimento de constitucionalização do Brasil foi regido pela contradição fundamental entre o patrimonialismo e o liberalismo, obrando cada grupo em favor de seus próprios interesses e deixando o bem público em segundo plano, quando não descartado. Conforme Alfredo Varela:

Em vez de aperfeiçoar o que existia, [o legislador de 1824] fantasiou obra nova, em desaccordo com a tradição nacional. O resultado é que a Carta do Imperio nunca foi observada, como se collige dos proprios annaes parlamentares, pejados de lamentações sobre o constante sacrificio do fantastico equilíbrio dos poderes, cuja divina serenidade antegozavam tão ingenuamente os doctores constitucionaes do tempo de D. Pedro ${ }^{255}$.

${ }^{253}$ SOUSA, Joaquim Rodrigues de. Analyse e comentário da Constituição Politica do Imperio do Brazil: ou theoria e pratica do governo constitucional brazileiro. $1^{\mathrm{a}}$ ed. São Luiz do Maranhão: B. de Mattos, 1870. v2. P. 482.

${ }^{254}$ MIRANDA, Jorge. Textos históricos do Direito Constitucional. P. 226.

${ }^{255}$ VARELA, Alfredo. Direito constitucional brazileiro. P. 38. 


\section{Conclusão}

A dramática época em que vivemos, pondo em crise a legalidade, agrava e enobrece o dever de luta pela preservação e pelo aperfeiçoamento da ordem jurídica, numa tarefa grandiosa, que ultrapassando o dia-a-dia da rotina, se mede pela defesa da sobrevivência do próprio Direito, como valor permanente para a vida do homem com paz, bem-estar e progresso. (...) Pois esse mundo de intolerância, e, por isto mesmo, propenso às injustiças que a paixão dos intolerantes soe multiplicar, faz avultar a significação do advogado ${ }^{256}$.

Embora proferidas por Miguel Seabra Fagundes há quase cinquenta anos, as palavras acima são mais atuais do que nunca. Parece que as fartas experiências autoritárias do Brasil, verdadeiro traço da nossa história, foram, mais uma vez, esquecidas pelo povo - mantido intencionalmente ignorante, a favorecer os eternos coronéis do país. Ocorre ciclicamente com o Brasil o que Baruch de Spinoza já alertava: "os homens, uma vez libertados do medo pela paz, tornam-se, pouco a pouco, os selvagens e bárbaros que eram, em vez de seres civilizados e humanos, e daí caem na moleza e na preguiça" $" 257$.

As (cada vez mais) frequentes incitações a soluções antijurídicas para os problemas do país, sustentadas no privilégio da violência e na supressão das garantias individuais, refletem a imagem medonha de uma índole nacional que nunca foi educada para lidar com a oposição através de estudo e discussão racional. Os horrores da ditadura civil-militar foram escondidos e relativizados, tudo na busca fugaz por uma união nacional que desconsidera punições justas e vilipendia a memória dos que ousam reagir $^{258}$. Lamentavelmente, em relação ao Brasil, sempre foi assim.

O patrimonialismo e a concentração de riquezas, práticas iniciadas no país pelos grandes produtores de cana-de-açúcar nos idos do século XVI,

\footnotetext{
${ }^{256}$ SEABRA FAGUNDES, Miguel. A legalidade democrática. $1^{\mathrm{a}}$ ed. Recife: OAB/PE, 1970. P. 11 e 12.

${ }^{257}$ SPINOZA, Baruch de. Tratado político. P. 144.

${ }^{258}$ Vide a Lei $\mathrm{n}^{\circ}$ 6.683, de 28 de agosto de 1979 (BRASIL. Lei $n^{\circ} 6.683$, de 28 de agosto de 1979. Disponível em http://www.planalto.gov.br/ccivil_03/leis/L6683.htm. Acesso em 18.11.2018).
} 
se tornaram aspectos fundamentais do regime político brasileiro, tomando várias formas ao longo do tempo. À época da Independência, os representantes dessa classe eram principalmente mercadores portugueses e membros da "nobreza parasitária" que veio ao Rio de Janeiro com D. João VI. No início da República Velha, eram os antigos coronéis do interior. Hoje, essa distinta classe concentra políticos e empresários: nada mais tradicional, neste país, do que a aliança entre a nobreza e a burguesia.

Todos os movimentos revolucionários bem-sucedidos na história do Brasil possuem três semelhanças fundamentais: foram orquestrados por elites, sem grande participação popular; utilizaram a violência para atingir o poder; e tentaram romantizar e suavizar a visão histórica desses eventos. Não é à toa que, na aurora da República Velha, se revisitou a memória da Inconfidência Mineira para resgatar a figura de Joaquim José da Silva Xavier, o Tiradentes, transmutando-o de bandido subversivo em herói nacional $^{259}$. Esse movimento ocorreu aos mandos da classe dominante, ansiosa por legitimar a nova forma de governo perante o povo - este último, personagem mais uma vez passivo durante a revolução republicana.

Da mesma forma, a ideologia e a política moldaram a visão histórica sobre os episódios que conduziram à Independência; rodeados de mistério e glória, os conflitos, as proclamações e os ideais bradados pelos agentes da revolução se tornaram míticos através da doutrinação consciente e. Seriam ensinados e repetidos por todo o território, representando uma forma eficiente de padronizar e pacificar o pensamento sobre o novo país para gerar a tão sonhada coesão nacional.

\footnotetext{
${ }^{259}$ Foi, inclusive, o primeiro a ter seu nome inscrito no Livro de Aço dos Heróis Nacionais, situado no Panteão da Pátria e da Liberdade Tancredo Neves (GOVERNO DO DISTRITO FEDERAL. Panteão da Pátria. Disponível em http://www.df.gov.br/panteao-da-patria/. Acesso em 18.11.2018).
} 
A nacionalidade e a cultura brasileiras, esculpidas em grande parte pelos caprichos de grupos no poder, encerram uma deficiência grave. Nosso modelo político tradicional funciona por meio da alienação da massa popular e de sua fraca participação nos processos decisórios ${ }^{260}$, o que aumenta a distância entre os cidadãos e seus representantes. A época da ditadura volta a ser pertinente para esta análise:

Uma análise, ainda que perfunctória, da ordem jurídica no Brasil leva à conclusão melancólica de que ela é ilegítima porque integrada por normas elaboradas sem a participação de seus destinatários, raramente consultados sobre o seu conteúdo. (...) Esse divórcio entre a vontade da lei e a da coletividade determina a ineficácia da ordem jurídica, que, não resultando da vontade do grupo social, é ilegítima e, por isso, não pode disciplinar, convenientemente, a conduta de seus integrantes ${ }^{261}$.

Historicamente, o instrumento favorito do Estado brasileiro para garantir o cumprimento das leis pelo povo tem sido a polícia (quando não a tortura). Segundo Walter Benjamin, o uso desmedido da força policial evidencia uma fraqueza institucional, representando um momento em que o Estado "não está já em condições de garantir (...) seus fins empíricos, que pretende atingir a qualquer preço. Por isso que a polícia intervém em numerosos casos 'por razões de segurança', quando a situação legal não é clara" $^{, 262}$.

A falta de consciência histórica no país, ainda que intencional, gera uma aparência de estagnação em termos morais, resultado direto da tradicional concentração de poderes e influências que nos define há séculos. Por isso, eventos narrados neste texto podem parecer tristemente atuais. Fala-se de incidentes como o protocolo secreto em que o Brasil pagava pela sua Independência, o deputado constituinte preso e libertado por seus pares,

\footnotetext{
${ }^{260}$ A título de exemplo, basta lembrar que mesmo as deliberações para alguns de nossos maiores diplomas legais (Código Teixeira de Freitas, Código Bevilaqua, Código Reale) foram feitas à revelia da opinião pública, por círculos de "notáveis".

${ }^{261}$ BERMUDES, Sergio. A tutela jurisdicional da liberdade. $1^{\mathrm{a}}$ ed. Manaus: OAB, 1980. P. 2.

${ }^{262}$ BENJAMIN, Walter. O anjo da história. $2^{\mathrm{a}}$ ed. Belo Horizonte: Autêntica, 2013. P. 69.
} 
a manipulação política pela imprensa, a truculência de soldados contra o boticário David Pamplona e a intimidação militar em torno da Assembleia Constituinte. Não foram os únicos.

Sendo a História "o choque entre a tradição e a organização política"263, o cenário brasileiro parece natural ou, no mínimo, esperado. A fraqueza permanente da articulação popular favorece a manutenção das nossas tradições violentas, e mesmo as mobilizações recentes não parecem ter feito muito contra elas - ao menos até agora. Estaria certo José Bonifácio quando, contrariando a epígrafe deste texto, disse que "falsidade e dissimulação fazem o caráter geral dos brasileiros" ${ }^{\text {264 }}$ ? Devemos acreditar que não.

O ilusório pessimismo brasileiro, a constante sensação de viver uma crise inescapável, são frutos inconscientes de um povo que sofreu muito e não possui as informações para fazer paz com sua história. A supressão da memória, seja pela romantização de episódios como os da Independência, seja pela violência policial intrínseca, seja pelos sucessivos golpes de Estado a que estamos sujeitos, constrói as raízes de um país que sempre ficaria "para o futuro".

Frente à intolerância e ao agravamento das tensões políticas, que põem em risco todo o sistema democrático conquistado duramente, não pode haver outra posição senão resistir e reagir. Será preciso lembrar a realidade de nossa história, sua pertinência atual e os erros do passado. Que se conheça e se entenda a Independência do Brasil como realmente foi: cheia de conflitos, mortes, absurdos jurídicos e dissimulações. Que esse conhecimento seja, assim, usado para quebrar o ciclo nefasto do qual nunca conseguimos nos afastar.

\footnotetext{
${ }^{263}$ BENJAMIN, Walter. O anjo da história. P. 33.

${ }^{264}$ ANDRADA E SILVA, José Bonifácio de. Projetos para o Brasil. P. 99.
} 


\section{Bibliografia}

ACCIOLI, Wilson. Reforma e contra-reforma na Constituição de 1824. Revista de Informação Legislativa. Brasília, v. 11, n 43, p. 154-161, jul./set. 1974.

ALMEIDA GARRETT, João Baptista da Silva Leitão de. Portugal na balança da Europa: do que tem sido e do que ora lhe convém ser na nova ordem de coisas do mundo civilizado. $2^{\mathrm{a}}$ ed. Lisboa: Livros Horizonte, 2005. 133 p.

ANDRADA E SILVA, José Bonifácio de. Projetos para o Brasil. $1^{\mathrm{a}}$ ed. São Paulo: Companhia das Letras e Publifolha, 2000. 212 p.

ARMITAGE, John. História do Brasil: desde o período da chegada da família de Bragança, em 1808, até a abdicação de D. Pedro I, em 1831. $1^{\text {a }}$ ed. Brasília: Senado Federal, 2011. 452 p.

BANDEIRA DE MELLO, Celso Antônio. Conteúdo jurídico do princípio da igualdade. $3^{\text {a }}$ ed. São Paulo: Malheiros, 1993. 48 p.

BENJAMIN, Walter. $O$ anjo da história. $2^{\mathrm{a}}$ ed. Belo Horizonte: Autêntica, 2013. $261 \mathrm{p}$.

BARBOSA, Rui. Os conceitos modernos do Direito Internacional. $1^{\text {a }}$ ed. Rio de Janeiro: Fundação Casa de Rui Barbosa, 1983. 127 p.

BERMUDES, Sergio. A tutela jurisdicional da liberdade. $1^{\mathrm{a}}$ ed. Manaus: OAB, 1980.5 p.

BEVILAQUA, Clovis. Juristas philosophos. $1^{\mathrm{a}}$ ed. Salvador: Magalhães, 1897. $143 \mathrm{p}$.

BICUDO, Hélio Pereira. O Direito e a Justiça no Brasil: uma análise crítica de cem anos. $1^{\mathrm{a}}$ ed. São Paulo: Símbolo, 1978. 240 p. 
BITAR, Orlando. Missão constitucional de Pedro I. In:__. Obras completas de Orlando Bitar: estudos de Direito Constitucional e Direito do Trabalho. $1^{\mathrm{a}}$ ed. Rio de Janeiro: Renovar, 1996. v2. P. 309-328.

BOBBIO, Norberto. Estado, governo, sociedade: para uma teoria geral da política. $1^{\mathrm{a}}$ ed. Rio de Janeiro: Paz e Terra, 1987. 173 p.

BONAVIDES, Paulo; ANDRADE, Antonio Paes de. História constitucional do Brasil. $3^{\mathrm{a}}$ ed. São Paulo: Paz e Terra, 1991. 955 p.

BONAVIDES, Paulo. Teoria Geral do Estado. $10^{\mathrm{a}}$ ed. São Paulo: Malheiros, 2015. 600 p.

BRASIL. Ata da Primeira Sessão Ordinária da Assembleia, 03.05.1823. Disponível em https://arquivohistorico.camara.leg.br/index.php/ata-daprimeira-sessao-da-assembleia. Acesso em 11.08.2018. P. 18.

BRASIL. Coleção das Leis do Império (1821-1830). Disponível em http://www2.camara.leg.br/atividade-

legislativa/legislacao/publicacoes/doimperio/colecao2.html. Acesso em 21.07.2018.

BRASIL. Decreto de 3 de junho de 1822. Disponível em http://www.ibrade.org/wp-content/uploads/2018/03/Decreto-de-3-de-junhode-1822.pdf. Acesso em 06.08.2018.

BRASIL. Indicação n. 1 para se processar o autor da carta inserta no $\begin{array}{lllll}\text { Diário do } & \text { Governo } & \text { 124. Disponível em }\end{array}$ https://arquivohistorico.camara.leg.br/index.php/indicacao-n-1-para-seprocessar-o-autor-da-carta-inserta-no-diario-do-governo-n-124. Acesso em 15.08.2018.

BRASIL. Lei de 20 de setembro de 1830. Disponível em http://www2.camara.leg.br/legin/fed/lei_sn/1824-1899/lei-37987-20- 
setembro-1830-565654-publicacaooriginal-89402-pl.html. Acesso em 11.10.2018.

BRASIL. Lei $n^{o}$ 6.683, de 28 de agosto de 1979. Disponível em http://www.planalto.gov.br/ccivil 03/leis/L6683.htm. Acesso em 18.11.2018.

BUENO, Eduardo. A coroa, a cruz e a espada: lei, ordem e corrupção no Brasil. $1^{a}$ ed. Rio de Janeiro: Estação Brasil, 2016. 288 p.

BURKE, Edmund. Reflexões sobre a Revolução em França. $1^{\mathrm{a}}$ ed. Brasília: Ed. UNB, 1982. 239 p.

CAETANO, Marcello. História do direito português: 1140-1495. $1^{\mathrm{a}}$ ed. Lisboa: Verbo, 1981. 592 p.

CALMON, Pedro. História da civilização brasileira. $1^{\mathrm{a}}$ ed. Brasília: Senado Federal, 2002. 332 p.

CANECA, Frei Joaquim do Amor Divino. Ensaios políticos. $1^{\mathrm{a}}$ ed. Rio de Janeiro: Documentário, 1976. 107 p.

CARVALHO, José Murilo de et al (Org.). Às armas, cidadãos!: panfletos manuscritos da Independência do Brasil (1820-1823). $1^{a}$ ed. Rio de Janeiro: Companhia das Letras e Editora Ufmg, 2012. 240 p.

CASTRO, Flávia Lages de. História do direito: geral e Brasil. $8^{\mathrm{a}}$ ed. Rio de Janeiro: Lumen Juris, 2011. 577 p.

CERQUEIRA, Marcello. A constituição na história: origem e reforma. $1^{\mathrm{a}}$ ed. Rio de Janeiro: Revan, 1993. 448 p.

CONSELHO NACIONAL DE JUSTIÇA. Dados das inspeções nos estabelecimentos penais - Geopresídios. Disponível em http://www.cnj.jus.br/inspecao_penal/mapa.php. Acesso em 16.10.2018. 
CONSTANT, Benjamin. Princípios de política aplicáveis a todos os governos. $1^{\mathrm{a}}$ ed. Rio de Janeiro: Topbooks, 2007. 936 p.

CONSTANT, Benjamin. Principios de politica. $1^{\mathrm{a}}$ ed. Madrid: Aguilar, 1970. $180 \mathrm{p}$.

DEIRÓ, Pedro Eunápio da Silva. Fragmentos de estudos da história da Assembleia Constituinte do Brasil. 1ª ed. Brasília: Senado Federal, 2006. $364 \mathrm{p}$.

FAORO, Raymundo. Assembleia Constituinte: a legitimidade recuperada. $1^{\mathrm{a}}$ ed. São Paulo: Brasiliense, 1981. 98 p.

FAORO, Raymundo. Os donos do poder: formação do patronato político brasileiro. $5^{\text {a }}$ ed. São Paulo: Globo, 2012. 929 p.

FAUSTO, Boris; HOLANDA, Sergio Buarque de. História Geral da Civilização Brasileira: o Brasil monárquico: o processo de emancipação. $2^{\mathrm{a}}$ ed. São Paulo: Difusão Europeia do Livro, 1965. 410 p.

FERREIRA FILHO, Manoel Gonçalves. O poder constituinte. $4^{\mathrm{a}}$ ed. São Paulo: Saraiva, 2005. 253 p.

FURTADO, Celso. Formação econômica do Brasil. 17ª ed. São Paulo: Ed. Nacional, 1980. 248 p.

GOVERnO DO DISTRITO FEDERAL. Panteão da Pátria. Disponível em http://www.df.gov.br/panteao-da-patria/. Acesso em 18.11.2018

HESSE, Konrad. A força normativa da Constituição. $1^{\mathrm{a}}$ ed. Porto Alegre: Sergio Antonio Fabris Editor, 1991. 34 p.

HOBSBAWM, Eric J. A era das revoluções: 1789-1848. 25ª ed. São Paulo: Paz e Terra, 2011. 536 p. 
HOLANDA, Sergio Buarque de. Para uma pré-história do Império do Brasil. In:_. Capítulos de história do Império. $1^{\mathrm{a}}$ ed. São Paulo: Companhia das Letras, 2010. Parte I, Cap. 1, p. 15-38.

HOMEM DE MELLO, Francisco Inácio Marcondes. A Constituinte perante a História. $1^{\mathrm{a}}$ ed. Rio de Janeiro: Actualidade, 1863. 199 p.

KELSEN, Hans. A Justiça e o Direito Natural. $2^{\text {a }}$ ed. Coimbra: Arménio Amado, 1979. 175 p.

KISSINGER, Henry. Diplomacy. $1^{\mathrm{a}}$ ed. New York: Simon \& Schuster, 1994. $912 \mathrm{p}$.

LASSALLE, Ferdinand. A essência da Constituição. $9^{\mathrm{a}}$ ed. Rio de Janeiro: Freitas Bastos, 2014. 54 p.

LEAL, Aurelino. História constitucional do Brasil. $1^{\mathrm{a}}$ ed. Brasília: Senado Federal, 2014. 197 p.

LEAL, Victor Nunes. Coronelismo, enxada e voto: o município e o regime representativo no Brasil. $7^{\mathrm{a}}$ ed. São Paulo: Companhia das Letras, 2012. 363 p.

LENIN, Vladimir Ilitch. O Estado e a Revolução: o que ensina o marxismo sobre o Estado e o papel do proletariado na Revolução. $1^{a}$ ed. São Paulo: Centauro, 2007. 168 p.

LIMA LOPES, José Reinaldo de. $O$ Direito na História: lições introdutórias. 5a ed. São Paulo: Atlas, 2014. 467 p.

MARQUES, Xavier. Ensaio histórico sobre a Independência. $2^{\mathrm{a}}$ ed. Rio de Janeiro: Instituto Nacional do Livro, 1977. 173 p.

MELLO, Evaldo Cabral de. A outra Independência: o federalismo pernambucano de 1817 a 1824. 2a ed. São Paulo: Editora 34, 2004. 264 p. 
MELLO FRANCO, Afonso Arinos de. O Constitucionalismo brasileiro na primeira metade do século XIX. In:__. Estudos de direito constitucional. $1^{\mathrm{a}}$ ed. Rio de Janeiro: Forense, 1957. Cap. VI, p. 221-256.

MELLO MORAES, Alexandre José de. Chronica geral e minuciosa do Império do Brasil desde a descoberta do novo mundo ou América até o anno de 1879. Ed. fac-sim. Brasília: Senado Federal, 1997. 208 p.

MIRANDA, Jorge. Textos históricos do Direito Constitucional. $1^{\mathrm{a}}$ ed. Lisboa: Imprensa Nacional, 1980. 366 p.

MONTEIRO, Tobias. História do Império: a elaboração da Independência. $1^{\mathrm{a}}$ ed. Belo Horizonte: Itatiaia, 1981. 817 p.

MONTESQUIEU, Charles de Secondat, Baron de. Do espírito das leis. $1^{\mathrm{a}}$ ed. São Paulo: Martin Claret, 2014. 883 p.

MOTA, Carlos Guilherme. Europeus no Brasil à época da independência: um estudo. In:__ (Org.). 1822: dimensões. $1^{\mathrm{a}}$ ed. São Paulo: Perspectiva, 1972. P. 56-73.

NABUCO, Joaquim. O abolicionismo. $4^{\mathrm{a}}$ ed. Petrópolis: Vozes, 1977. 208 p.

NOVAIS, Fernando Antônio. Portugal e Brasil na crise do antigo sistema colonial: 1777-1808. 1ª ed. São Paulo: Hucitec, 1979. 420 p.

OLIVEIRA LIMA, Manuel de. D. João VI no Brasil. $4^{\text {a }}$ ed. Rio de Janeiro: Topbooks, 2006. 790 p.

OLIVEIRA LIMA, Manuel de. Formação histórica da nacionalidade brasileira. $2^{\text {a }}$ ed. Rio de Janeiro: Topbooks, 1997. 296 p.

OLIVEIRA LIMA, Manuel de. O movimento da Independência: 18211822. $6^{\text {a }}$ ed. Rio de Janeiro: Topbooks, 1997. 493 p. 
OLIVEIRA LIMA, Manuel de. O reconhecimento do Império: história da diplomacia brasileira. $2^{\mathrm{a}}$ ed. Rio de Janeiro: Topbooks, 2015. 224 p.

PIMENTA BUENO, José Antonio. Direito público brasileiro e análise da Constituição do Império. $1^{\mathrm{a}}$ ed. Rio de Janeiro: Ministério da Justiça, 1958. 568 p.

PORTUGAL. Carta de Lei de 16 de dezembro de 1815. Disponível em http://www2.camara.leg.br/legin/fed/carlei/anterioresa1824/cartadelei39554-16-dezembro-1815-569929-publicacaooriginal-93095-pe.html. Acesso em 16.08.2018.

PORTUGAL. Carta Régia de 28 de janeiro de 1808. Disponível em http://www2.camara.leg.br/legin/fed/carreg sn/anterioresa1824/cartaregia35757-28-janeiro-1808-539177-publicacaooriginal-37144-pe.html. Acesso em 08.06.2018.

PRADO JR, Caio. Formação do Brasil contemporâneo. $1^{\mathrm{a}}$ ed. São Paulo: Companhia das Letras, 2011. 464 p.

PRADO JR, Caio. Evolução política do Brasil: colônia e império. $16^{\mathrm{a}}$ ed. São Paulo: Brasiliense, 1988. 102 p.

PROENÇA, Maria Cândida. A Independência do Brasil: relações externas portuguesas, 1808/1825. $1^{\mathrm{a}}$ ed. Lisboa: Livros Horizonte, 1987. 135 p.

REZEK, José Francisco. Direito dos Tratados. $1^{\mathrm{a}}$ ed. Rio de Janeiro: Forense, 1984. 628 p.

RICOEUR, Paul. História e verdade. $1^{\mathrm{a}}$ ed. Rio de Janeiro: Forense, 1968. $340 \mathrm{p}$.

RICUPERO, Rubens. A diplomacia na construção do Brasil: 1750-2016. $1^{\text {a }}$ ed. Rio de Janeiro: Versal, 2017. 781 p. 
ROCHA, Antonio Penalves. A Recolonização do Brasil pelas Cortes: história de uma invenção historiográfica. $1^{\mathrm{a}}$ ed. São Paulo: Unesp, 2009. $134 \mathrm{p}$.

RODRIGUES, José Honório. Independência: revolução e contrarevolução: a evolução política. $1^{\mathrm{a}}$ ed. Rio de Janeiro: F. Alves, 1975. v1. 389 p.

RODRIGUES, José Honório. Independência: revolução e contrarevolução: a liderança nacional. $1^{a}$ ed. Rio de Janeiro: F. Alves, 1975 . v4. $210 \mathrm{p}$.

RODRIGUES, José Honório. Independência: revolução e contrarevolução: a política internacional. $1^{\mathrm{a}}$ ed. Rio de Janeiro: F. Alves, 1975. v5. 343 p.

ROURE, Agenor de. Formação constitucional do Brasil. $1^{\mathrm{a}}$ ed. Brasília: Senado Federal, 2016. 360 p.

SALDANHA, Nelson Nogueira. História das ideias políticas no Brasil. $1^{\mathrm{a}}$ ed. Brasília: Senado Federal, 2001. 384 p.

SCHMITT, Carl. Dottrina della costituzione. $1^{\text {a }}$ ed. Milano: Giuffrè, 1984. $537 \mathrm{p}$.

SEABRA FAGUNDES, Miguel. A legalidade democrática. $1^{\mathrm{a}}$ ed. Recife: OAB/PE, 1970. 30 p.

SEABRA FAGUNDES, Miguel. A legitimidade do poder político na experiência brasileira. $1^{\mathrm{a}}$ ed. Recife: OAB/PE, 1982. 30 p.

SIEYÈS, Emmanuel Joseph. ¿Qué es el tercer estado?. $1^{\mathrm{a}}$ ed. Madrid: Aguilar, 1973. 120 p.

SILVA, José Afonso da. Curso de direito constitucional positivo. $38^{\mathrm{a}}$ ed. São Paulo: Malheiros, 2015. 936 p. 
SILVA, José Afonso da. $O$ constitucionalismo brasileiro: evolução institucional. $1^{a}$ ed. São Paulo: Malheiros, 2011. 544 p.

SILVA, José Afonso da. Poder constituinte e poder popular: estudos sobre a Constituição. $1^{a}$ ed. São Paulo: Malheiros, 2000. 308 p.

SILVA, Maria Beatriz Nizza da. Diário Constitucional: um periódico baiano defensor de D. Pedro - 1822. 1ª ed. Salvador: Ed. UFBA, 2011. 195 p.

SILVA, Maria Beatriz Nizza da (Coord.). O Império Luso-Brasileiro (1750-1822). $1^{a}$ ed. Lisboa: Estampa, 1986. 613 p.

SISSON, Sébastien Auguste. Galeria dos brasileiros ilustres. $1^{\mathrm{a}}$ ed. Brasília: Senado Federal, 1999. v2. 492 p.

SOUSA, Joaquim Rodrigues de. Analyse e comentário da Constituição Politica do Imperio do Brazil: ou theoria e pratica do governo constitucional brazileiro. $1^{\mathrm{a}}$ ed. São Luiz do Maranhão: B. de Mattos, 1867. v1. $442 \mathrm{p}$.

SOUSA, Joaquim Rodrigues de. Analyse e comentário da Constituição Politica do Imperio do Brazil: ou theoria e pratica do governo constitucional brazileiro. $1^{\mathrm{a}}$ ed. São Luiz do Maranhão: B. de Mattos, 1870. v2. $483 \mathrm{p}$.

SPINOZA, Baruch de. Tratado político. $2^{a}$ ed. São Paulo: Ícone, 1994. 152 p.

VALLADÃO, Alfredo. Da aclamação à maioridade e outros trabalhos históricos: 1822-1840. $3^{\mathrm{a}}$ ed. Rio de Janeiro: Freitas Bastos, 1973. 457 p.

VARELA, Alfredo. Direito constitucional brazileiro: reforma das instituições nacionaes. $1^{a}$ ed. Rio de Janeiro: Typographia, 1899. 379 p. 
VARNHAGEN, Francisco Adolpho de. História da independência do Brasil: até ao reconhecimento pela antiga metrópole, compreendendo, separadamente, a dos sucessos ocorridos em algumas províncias até essa data. $1^{a}$ ed. Brasília: Senado Federal, 2010. 548 p.

WOLKMER, Antônio Carlos. História do direito no Brasil. $3^{\mathrm{a}}$ ed. Rio de Janeiro: Forense, 2002. 167 p. 